\title{
Thermochemical properties and dehydrogenation thermodynamics of indole derivates
}

\author{
Maria E. Konnova, ${ }^{a}$ Shao Li, ${ }^{b}$ Andreas Bösmann, ${ }^{b}$ Karsten Müller, ${ }^{c,, e d *}$ Peter Wasserscheid, ${ }^{b, d}$ \\ Irina V. Andreeva, ${ }^{f}$ V.V. Turovtzev, ${ }^{g}$ Dzmitry H. Zaitsau, ${ }^{f}$ Aleksey A. Pimerzin, ${ }^{a}$ Sergey P. \\ Verevkin $^{a, f^{*}}$ \\ ${ }^{a}$ Chemical Department, Samara State Technical University, 443100 Samara, Russia \\ ${ }^{b}$ Lehrstuhl für Chemische Reaktionstechnik, Friedrich-Alexander-Universität Erlangen-Nürnberg, Egerlandstr. \\ 3, 91058 Erlangen, Germany \\ ${ }^{c}$ Lehrstuhl für Thermische Verfahrenstechnik, Friedrich-Alexander-Universität Erlangen-Nürnberg, \\ Egerlandstr. 3, 91058 Erlangen, Germany \\ ${ }^{d}$ Forschungszentrum Jülich GmbH, Helmholtz Institute Erlangen-Nürnberg for Renewable Energy (IEK-11), \\ Egerlandstr. 3, 91058 Erlangen, Germany \\ ${ }^{e}$ Lehrstuhl für Technische Thermodynamik, Universität Rostock, Albert Einstein Str. 2, 18059 Rostock, Germany \\ f Department of Physical Chemistry and Department „Science and Technology of Life, Light and Matter“, \\ Universität Rostock, Dr-Lorenz-Weg 2, 18059, Rostock, Germany \\ ${ }^{g}$ Department of Physics, Tver State Medical University, 170100 Tver, Russia
}

\section{Content}

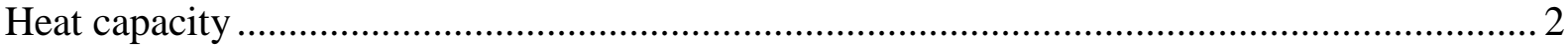

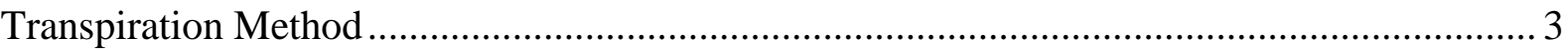

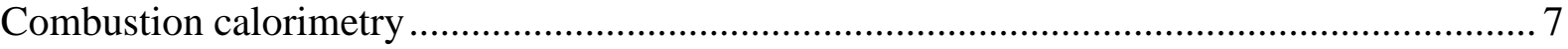

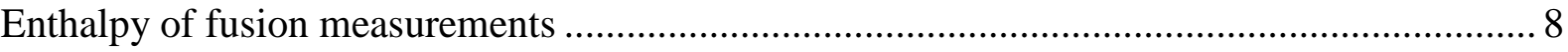

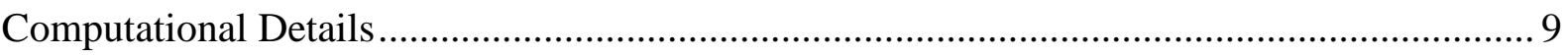

Correlations of vaporization enthalpies with gas-chromatographic indices. .......................... 10

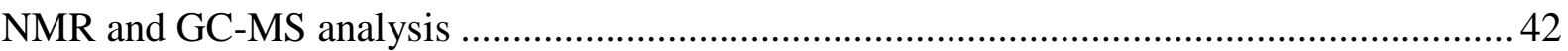

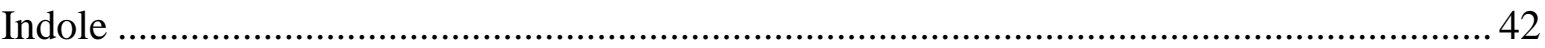

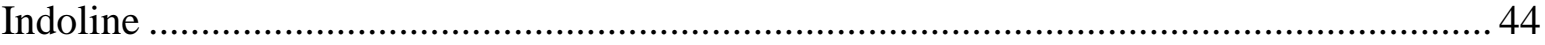

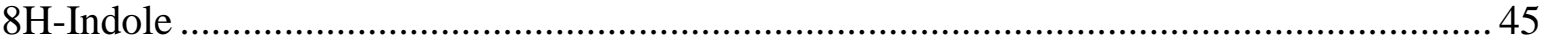

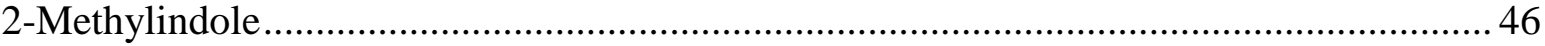

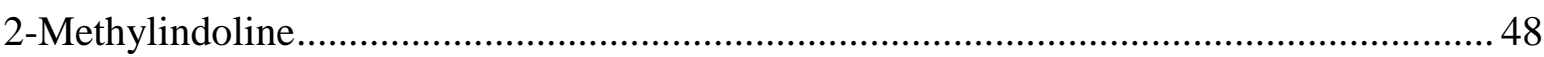

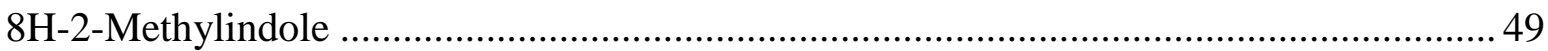

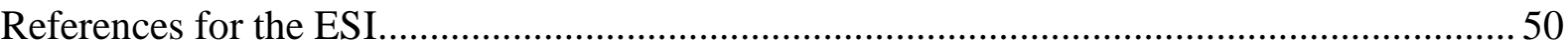




\section{Heat capacity [S1]}

The experimental protocol of heat capacity determination included the three equal iterations with an empty pan, a reference sample of sapphire and a sample of each compound being researched. For each iteration there was an equal thermal program of study; for all steps of each measurement the same pan was used. In each iteration the sample was heated with the step of $50 \mathrm{~K}$ at heating rate of $10 \mathrm{~K} \cdot \mathrm{min}-1$. Before and after each scanning step sample was kept isothermally for two minutes. Inside each iteration the temperature range was divided into intervals of $50 \mathrm{~K}$ to heat samples and between them there was a shift of $25 \mathrm{~K}$. Each step for all iterations was repeated 4 times.

The heat capacity was derived with the Perkin Elmer software. The heat capacity determination technique was tested with a reference sample of benzoic acid by Parr Instrument Company. In the chosen temperature ranges the experimental values agreed with the reference values within $\pm 1 \%$. The expanded uncertainty $(\mathrm{k}=2)$ for the heat capacity measured by this method was estimated to be $0.02 \times C_{\mathrm{p}, \mathrm{m}}^{\mathrm{m}}$.

Table S1: Compilation of data on molar heat capacities $C_{\mathrm{p}, \mathrm{m}}^{\mathrm{o}}\left(\mathrm{cr}\right.$ or liq) (in $\left.\mathrm{J} \cdot \mathrm{K}^{-1} \cdot \mathrm{mol}^{-1}\right)$ at $T=298.15 \mathrm{~K}$ for indole, indoline, and $8 \mathrm{H}$-indole

\begin{tabular}{|c|c|c|c|c|c|}
\hline & indole & & indoline & & 8H-indole \\
\hline$T, \mathrm{~K}$ & $C_{\mathrm{p}, \mathrm{m}}^{\mathrm{o}}(\mathrm{cr}$ or liq $)$ & $T, \mathrm{~K}$ & $C_{\mathrm{p}, \mathrm{m}}^{\mathrm{o}}(\mathrm{liq})$ & $T, \mathrm{~K}$ & $C_{\mathrm{p}, \mathrm{m}}^{\mathrm{o}}(\mathrm{liq})$ \\
\hline solid & & liquid & & liquid & \\
\hline 240 & 121.99 & 236 & 202.16 & 259 & 238.14 \\
\hline 244 & 124.57 & 238 & 202.70 & 261 & 238.08 \\
\hline 249 & 118.24 & 243 & 203.88 & 266 & 238.04 \\
\hline 254 & 118.26 & 248 & 205.19 & 271 & 238.24 \\
\hline 259 & 133.68 & 253 & 206.48 & 276 & 238.49 \\
\hline 264 & 137.55 & 258 & 207.94 & 281 & 238.93 \\
\hline 269 & 140.55 & 263 & 209.29 & 286 & 240.47 \\
\hline 274 & 143.70 & 268 & 210.68 & 291 & 241.03 \\
\hline 279 & 147.32 & 273 & 212.07 & 296 & 241.74 \\
\hline 284 & 150.58 & 278 & 213.63 & 301 & 243.09 \\
\hline 289 & 154.22 & 283 & 215.11 & 307 & 244.16 \\
\hline 294 & 158.13 & 288 & 216.58 & 311 & 244.79 \\
\hline 298 & 162.15 & 293 & 218.04 & 316 & 246.36 \\
\hline 314 & 178.41 & 298 & 219.50 & 321 & 248.25 \\
\hline 318 & 181.83 & 303 & 221.02 & 326 & 249.16 \\
\hline liquid & & 308 & 222.67 & 331 & 250.20 \\
\hline 341 & 207.03 & 313 & 224.22 & 336 & 251.80 \\
\hline 343 & 207.87 & 318 & 225.72 & 341 & 253.57 \\
\hline 345 & 208.51 & 323 & 227.13 & 346 & 255.39 \\
\hline 347 & 209.29 & 328 & 229.02 & 350 & 256.66 \\
\hline \multirow[t]{4}{*}{349} & 210.18 & 333 & 230.57 & & \\
\hline & & 338 & 232.10 & & \\
\hline & & 343 & 233.61 & & \\
\hline & & 348 & 235.14 & & \\
\hline
\end{tabular}


Table S2: Compilation of data on molar heat capacities $C_{\mathrm{p}, \mathrm{m}}^{\mathbf{0}}(\mathrm{cr}$ or liq) and heat capacity differences $\Delta_{\mathrm{l}}^{\mathrm{g}} C_{\mathrm{p}, \mathrm{m}}^{\mathrm{o}}\left(\right.$ in $\left.\mathrm{J} \cdot \mathrm{K}^{-1} \cdot \mathrm{mol}^{-1}\right)$ at $\mathrm{T}=\mathbf{2 9 8 . 1 5} \mathrm{K}$ for 2-methyl-indole, 2-methyl-indoline and 2-methyl-8H-indole

\begin{tabular}{|c|c|c|c|c|c|}
\hline & 2-Me-indole & & 2-Me-indoline & & 2-Me-8H-indole \\
\hline$T, \mathrm{~K}$ & $C_{\mathrm{p}, \mathrm{m}}^{\mathrm{o}}(\mathrm{cr}$ or liq) & $T, \mathrm{~K}$ & $C_{\mathrm{p}, \mathrm{m}}^{\mathrm{o}}(\mathrm{liq})$ & $T, \mathrm{~K}$ & $C_{\mathrm{p}, \mathrm{m}}^{\mathrm{o}}(\mathrm{liq})$ \\
\hline solid & & liquid & & liquid & \\
\hline 240 & 143.34 & 235 & 231.49 & 237 & 249.63 \\
\hline 244 & 145.64 & 240 & 233.03 & 242 & 250.36 \\
\hline 249 & 148.48 & 245 & 234.58 & 247 & 251.31 \\
\hline 254 & 151.33 & 250 & 236.18 & 252 & 252.42 \\
\hline 259 & 154.25 & 255 & 237.63 & 257 & 253.63 \\
\hline 264 & 157.51 & 260 & 239.27 & 262 & 254.89 \\
\hline 269 & 160.14 & 265 & 240.78 & 267 & 256.19 \\
\hline 274 & 162.79 & 270 & 242.33 & 272 & 257.65 \\
\hline 279 & 165.96 & 275 & 243.75 & 277 & 258.99 \\
\hline 284 & 168.69 & 280 & 245.43 & 282 & 260.69 \\
\hline 289 & 171.91 & 285 & 247.03 & 287 & 262.43 \\
\hline 294 & 174.77 & 290 & 248.58 & 292 & 264.29 \\
\hline 299 & 178.47 & 295 & 250.12 & 297 & 266.16 \\
\hline 304 & 184.03 & 300 & 251.61 & 302 & 268.01 \\
\hline 309 & 189.86 & 305 & 253.49 & 307 & 270.09 \\
\hline \multirow[t]{9}{*}{313} & 196.09 & 310 & 255.02 & 312 & 272.37 \\
\hline & & 315 & 256.53 & 317 & 274.62 \\
\hline & & 320 & 258.09 & 322 & 277.02 \\
\hline & & 325 & 259.56 & 327 & 279.20 \\
\hline & & 330 & 261.55 & 332 & 281.86 \\
\hline & & 335 & 263.29 & 337 & 284.34 \\
\hline & & 340 & 264.96 & 342 & 286.91 \\
\hline & & 345 & 266.48 & 347 & 289.49 \\
\hline & & 349 & 267.71 & 350 & 291.02 \\
\hline
\end{tabular}

\section{Transpiration Method [s2-s4]}

Vapour pressures of indole derivatives were measured using the transpiration method. About $0.8 \mathrm{~g}$ of the sample was mixed with small glass beads and placed in the thermostatted U-shaped saturator. A stream of $\mathrm{N}_{2}$ with a well-defined flow rate was passed through the saturator at constant temperature $( \pm 0.1 \mathrm{~K})$, and the transported material was collected in a cold trap. The amount of condensed substance was determined by GC. The saturation vapour pressure $p_{i}$ at each temperature $T_{i}$ was calculated from the amount of product collected within a definite period of time:

$$
p_{i}=m_{i} \cdot R \cdot T_{\mathrm{a}} / V \cdot M_{i} ; \quad V=\left(n_{\mathrm{N} 2}+n_{i}\right) \cdot R \cdot T_{\mathrm{a}} / P_{\mathrm{a}}
$$

where $V$ is the volume of the gas phase consisting of the $n_{\mathrm{N} 2}$ moles of the carrier gas and $n_{i}$ mole of gaseous compound under study at the atmospheric pressure $P_{\mathrm{a}}$ and the ambient temperature $T_{\mathrm{a}}$. The volume of the carrier gas $V_{\mathrm{N} 2}$ was determined by the digital flow rate sensor from integration with a microcontroller. We used the Honeywell S\&C - HAFBLF0200C2AX5 digital flow rate sensor with uncertainty at the level of $2.5 \%$. The flow rate of the nitrogen stream was also controlled by using a soap bubble flow meter (HP soap film flowmeter (model 0101-0113)) and optimized in order to reach the saturation equilibrium of the transporting gas at each 
temperature under study. The volume of the carrier gas $V_{\mathrm{N} 2}$ was readied from the digital flow rate sensor. The amount of the compound under study $n_{i}$ in the carrier gas was estimated applying the ideal gas law at each temperature. Prior to the beginning the vapour pressure measurements, the pre-conditioning of the sample was performed first at (293-300) $\mathrm{K}$ (one hour) in order to withdraw possible water traces. Then the saturator was kept at 310-315 K (in order to remove possible traces of volatile compounds). In order to ascertain the completing of pre-conditioning, three samples were taken during the sample flashing at a suitable temperature and analysed by the GC. A constant vapour pressure at this temperature indicated that the transpiration experiments could start. No additional impurities were detected by the GC analysis of the transported material. The absence of impurities and decomposition products was rechecked by GC analysis of the saturator content after completing of the whole series of experiments. The primary experimental data are given in Table S3.

Table S3. Results from the transpiration method: absolute vapour pressures $p_{i}$, standard molar sublimation/vaporization enthalpies $\Delta_{\mathrm{cr} / \mathrm{l}}^{\mathrm{g}} H_{m}^{\mathrm{o}}$ and standard molar sublimation/vaporization entropies $\Delta_{\mathrm{cr} / \mathrm{l}}^{\mathrm{g}} S_{m}^{\mathrm{o}}$

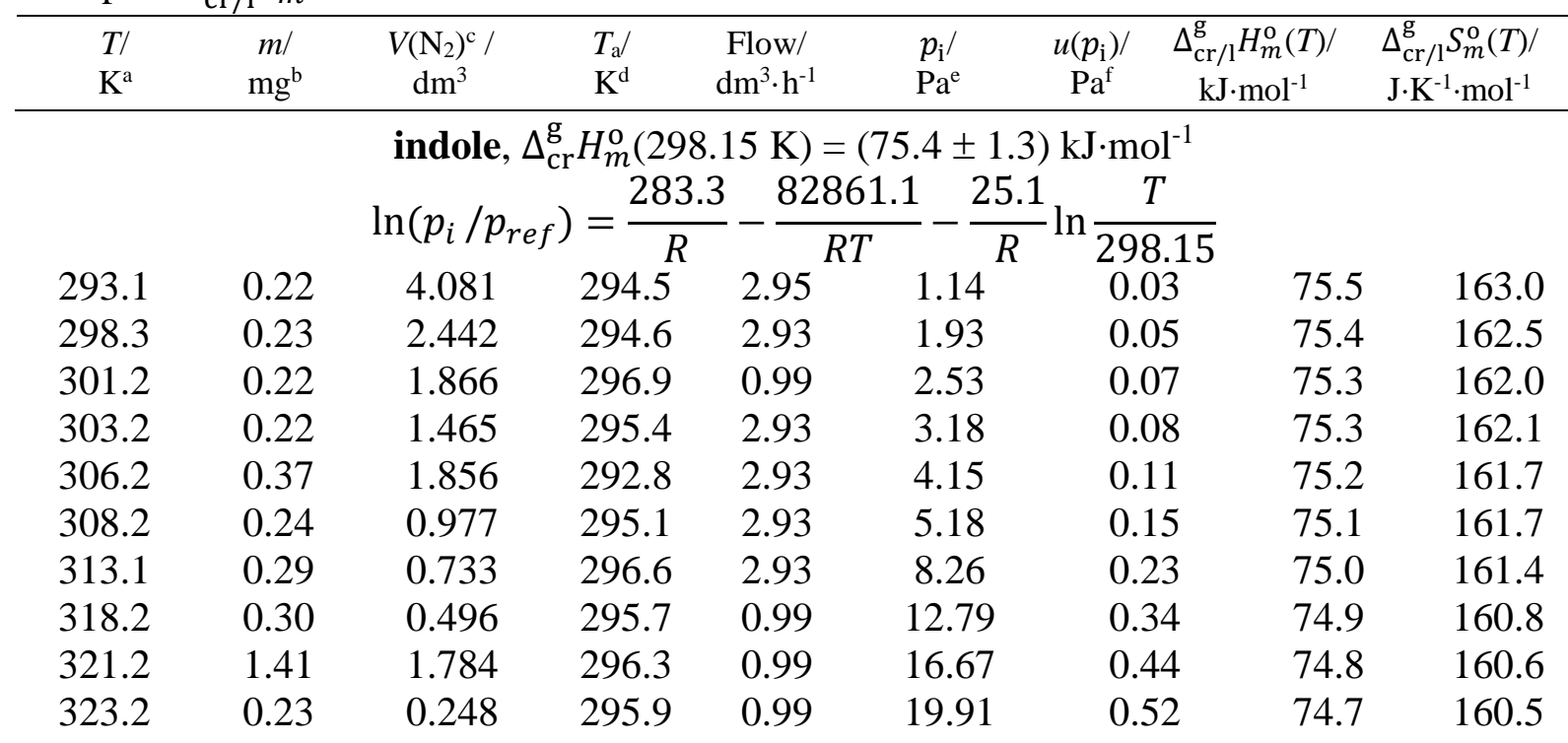

indoline. $\Delta_{\mathrm{l}}^{\mathrm{g}} H_{m}^{\mathrm{o}}(298.15 \mathrm{~K})=(60.5 \pm 0.6) \mathrm{kJ} \cdot \mathrm{mol}^{-1}$

\begin{tabular}{|c|c|c|c|c|c|c|c|c|}
\hline & & \multicolumn{2}{|c|}{$\ln \left(p_{i} / p_{\text {ref }}\right)=\frac{R}{R}$} & I & $R$ & 298.15 & & \\
\hline 288.7 & 1.51 & 6.000 & 296.5 & 3.60 & 5.27 & 0.16 & 61.1 & 129.8 \\
\hline 293.8 & 1.27 & 3.333 & 296.5 & 2.50 & 7.94 & 0.22 & 60.8 & 128.3 \\
\hline 296.6 & 1.22 & 2.500 & 296.5 & 2.50 & 10.12 & 0.28 & 60.6 & 127.8 \\
\hline 300.5 & 1.10 & 1.667 & 296.5 & 2.50 & 13.69 & 0.37 & 60.3 & 126.8 \\
\hline 305.2 & 1.48 & 1.542 & 296.5 & 2.50 & 19.91 & 0.52 & 60.0 & 125.7 \\
\hline 308.5 & 1.43 & 1.173 & 296.5 & 2.01 & 25.33 & 0.66 & 59.8 & 124.9 \\
\hline 315.2 & 2.47 & 1.208 & 296.5 & 2.50 & 42.34 & 1.08 & 59.3 & 123.6 \\
\hline 320.5 & 1.96 & 0.670 & 296.5 & 2.01 & 60.62 & 1.54 & 59.0 & 122.4 \\
\hline 325.6 & 2.76 & 0.670 & 296.5 & 2.01 & 85.18 & 2.15 & 58.6 & 121.3 \\
\hline 328.2 & 2.30 & 0.462 & 296.5 & 1.32 & 103.02 & 2.60 & 58.4 & 120.9 \\
\hline 333.1 & 3.54 & 0.510 & 296.5 & 1.53 & 143.61 & 3.62 & 58.1 & 120.0 \\
\hline 335.2 & 3.05 & 0.383 & 296.5 & 1.15 & 164.25 & 4.13 & 58.0 & 119. \\
\hline
\end{tabular}




$\begin{array}{ll}277.9 & 1.60 \\ 281.9 & 1.62 \\ 283.3 & 3.00 \\ 288.6 & 3.55 \\ 292.7 & 3.42 \\ 295.3 & 3.65 \\ 299.4 & 6.67 \\ 302.3 & 3.89 \\ 305.6 & 5.40 \\ 310.6 & 4.98 \\ 311.9 & 4.23 \\ 318.0 & 7.74 \\ 319.6 & 8.92 \\ 324.7 & 12.31 \\ 329.2 & 16.36\end{array}$

8H-indole, $\Delta_{\mathrm{l}}^{\mathrm{g}} H_{m}^{\mathrm{o}}(298.15 \mathrm{~K})=(53.5 \pm 0.7) \mathrm{kJ} \cdot \mathrm{mol}^{-1}$ $\ln \left(p_{i} / p_{\text {ref }}\right)=\frac{293.7}{R}-\frac{75474.3}{R T}-\frac{73.6}{R} \ln \frac{T}{298.15}$

$\begin{array}{lllllll}1.210 & 293.5 & 3.03 & 26.74 & 0.69 & 55.0 & 129.6 \\ 0.857 & 293.7 & 3.03 & 38.02 & 0.98 & 54.7 & 128.6 \\ 1.462 & 293.5 & 3.03 & 41.06 & 1.05 & 54.6 & 128.0 \\ 1.109 & 293.6 & 3.03 & 63.54 & 1.61 & 54.2 & 126.7 \\ 0.775 & 294.0 & 1.72 & 87.16 & 2.20 & 53.9 & 125.7 \\ 0.650 & 293.6 & 1.03 & 110.65 & 2.79 & 53.7 & 125.4 \\ 0.918 & 294.0 & 1.72 & 142.71 & 3.59 & 53.4 & 124.0 \\ 0.445 & 293.2 & 1.03 & 171.48 & 4.31 & 53.2 & 123.1 \\ 0.482 & 294.2 & 1.07 & 220.17 & 5.53 & 53.0 & 122.5 \\ 0.321 & 294.5 & 1.07 & 304.07 & 7.63 & 52.6 & 121.2 \\ 0.250 & 294.2 & 1.07 & 331.19 & 8.30 & 52.5 & 120.9 \\ 0.303 & 294.3 & 1.07 & 498.16 & 12.48 & 52.1 & 119.6 \\ 0.321 & 294.6 & 1.07 & 542.84 & 13.60 & 52.0 & 119.2 \\ 0.321 & 294.3 & 1.07 & 745.85 & 18.67 & 51.6 & 118.1 \\ 0.321 & 294.7 & 1.07 & 990.49 & 24.79 & 51.2 & 117.3\end{array}$

2-methyl-indole, $\Delta_{\mathrm{cr}}^{\mathrm{g}} H_{m}^{\mathrm{o}}(298.15 \mathrm{~K})=(85.1 \pm 1.2) \mathrm{kJ} \cdot \mathrm{mol}^{-1}$

\begin{tabular}{llllllllll}
\multicolumn{7}{c}{$\ln \left(p_{i} / p_{\text {ref }}\right)=\frac{304.5}{R}-\frac{93204.6}{R T}-\frac{27.1}{R} \ln \frac{T}{298.15}$} & & \\
298.3 & 0.14 & 6.687 & 294.7 & 2.95 & 0.38 & 0.01 & 85.1 & 181.6 \\
301.3 & 0.14 & 4.769 & 296.2 & 2.95 & 0.54 & 0.02 & 85.0 & 181.4 \\
303.1 & 0.07 & 2.105 & 293.4 & 2.94 & 0.66 & 0.02 & 85.0 & 181.2 \\
305.2 & 0.13 & 2.852 & 296.1 & 2.95 & 0.85 & 0.03 & 84.9 & 181.2 \\
308.1 & 0.13 & 2.154 & 294.3 & 2.94 & 1.14 & 0.03 & 84.9 & 180.8 \\
310.2 & 0.13 & 1.721 & 297.0 & 2.95 & 1.44 & 0.04 & 84.8 & 180.7 \\
313.0 & 0.15 & 1.469 & 295.4 & 2.94 & 1.92 & 0.05 & 84.7 & 180.3 \\
318.1 & 0.15 & 0.881 & 294.9 & 2.94 & 3.21 & 0.09 & 84.6 & 179.9 \\
323.1 & 0.12 & 0.435 & 295.5 & 1.00 & 5.23 & 0.16 & 84.4 & 179.4 \\
325.1 & 0.14 & 0.418 & 296.5 & 1.00 & 6.33 & 0.18 & 84.4 & 179.3 \\
328.0 & 0.16 & 0.351 & 295.7 & 1.00 & 8.45 & 0.24 & 84.3 & 179.0 \\
329.0 & 0.20 & 0.393 & 296.0 & 1.00 & 9.36 & 0.26 & 84.3 & 179.1 \\
330.1 & 0.14 & 0.259 & 296.3 & 1.00 & 10.43 & 0.29 & 84.3 & 179.0
\end{tabular}


2-methyl-indoline, $\Delta_{\mathrm{l}}^{\mathrm{g}} H_{m}^{\mathrm{o}}(298.15 \mathrm{~K})=(63.0 \pm 0.4) \mathrm{kJ} \cdot \mathrm{mol}^{-1}$

$$
\ln \left(p_{i} / p_{\text {ref }}\right)=\frac{307.7}{R}-\frac{85660.1}{R T}-\frac{75.9}{R} \ln \frac{T}{298.15}
$$

$\begin{array}{lllllllll}283.2 & 0.41 & 2.557 & 295.4 & 2.95 & 2.99 & 0.08 & 64.2 & 140.0 \\ 285.2 & 0.48 & 2.508 & 295.6 & 2.95 & 3.60 & 0.09 & 64.0 & 139.4 \\ 288.1 & 0.47 & 1.819 & 295.5 & 2.95 & 4.76 & 0.12 & 63.8 & 138.6 \\ 292.1 & 0.50 & 1.353 & 295.6 & 3.01 & 6.89 & 0.20 & 63.5 & 137.7 \\ 293.1 & 0.59 & 1.475 & 294.4 & 2.95 & 7.39 & 0.21 & 63.4 & 137.3 \\ 296.1 & 0.56 & 1.052 & 297.0 & 3.01 & 9.98 & 0.27 & 63.2 & 136.8 \\ 298.1 & 0.58 & 0.934 & 295.4 & 2.95 & 11.48 & 0.31 & 63.0 & 136.1 \\ 303.1 & 0.43 & 0.451 & 296.0 & 1.00 & 17.72 & 0.47 & 62.7 & 134.9 \\ 308.1 & 0.46 & 0.318 & 295.8 & 1.00 & 26.57 & 0.69 & 62.3 & 133.7 \\ 313.1 & 0.53 & 0.251 & 295.9 & 1.00 & 38.95 & 1.00 & 61.9 & 132.4 \\ 318.0 & 1.36 & 0.451 & 296.2 & 1.00 & 55.84 & 1.42 & 61.5 & 131.2 \\ 323.2 & 1.31 & 0.301 & 296.6 & 1.00 & 80.31 & 2.03 & 61.1 & 129.9 \\ 328.1 & 1.54 & 0.251 & 296.7 & 1.00 & 113.76 & 2.87 & 60.8 & 128.8 \\ 333.0 & 2.13 & 0.251 & 296.8 & 1.00 & 157.47 & 3.96 & 60.4 & 127.7\end{array}$

2-methyl-8H-indoline, $\Delta_{1}^{\mathrm{g}} H_{m}^{\mathrm{o}}(298.15 \mathrm{~K})=(57.8 \pm 0.8) \mathrm{kJ} \cdot \mathrm{mol}^{-1}$

\begin{tabular}{llllllllll} 
& \multicolumn{7}{c}{$\ln \left(p_{i} / p_{\text {ref }}\right)=\frac{311.3}{R}-\frac{81609.0}{R T}-\frac{79.9}{R} \ln \frac{T}{298.15}$} & & \\
275.1 & 0.30 & 0.432 & 295.8 & 1.00 & 12.78 & 0.34 & 59.6 & 142.2 \\
278.1 & 1.85 & 1.987 & 294.7 & 2.98 & 16.85 & 0.45 & 59.4 & 141.3 \\
280.2 & 0.37 & 0.333 & 295.9 & 1.00 & 20.28 & 0.53 & 59.2 & 140.7 \\
283.2 & 0.44 & 0.299 & 296.1 & 1.00 & 26.41 & 0.69 & 59.0 & 139.8 \\
287.1 & 1.50 & 0.749 & 296.1 & 1.00 & 35.82 & 0.92 & 58.7 & 138.4 \\
287.1 & 2.16 & 1.041 & 295.8 & 0.99 & 37.13 & 0.95 & 58.7 & 138.7 \\
288.2 & 1.94 & 0.864 & 296.5 & 3.05 & 40.17 & 1.03 & 58.6 & 138.2 \\
289.2 & 1.65 & 0.661 & 296.4 & 0.99 & 44.68 & 1.14 & 58.5 & 138.1 \\
290.1 & 1.72 & 0.628 & 294.2 & 0.99 & 48.67 & 1.24 & 58.4 & 138.0 \\
292.1 & 1.36 & 0.429 & 295.3 & 0.99 & 56.21 & 1.43 & 58.3 & 137.3 \\
292.2 & 1.64 & 0.516 & 296.4 & 1.00 & 56.65 & 1.44 & 58.3 & 137.2 \\
293.1 & 1.63 & 0.479 & 294.2 & 0.99 & 60.29 & 1.53 & 58.2 & 136.9 \\
295.1 & 1.59 & 0.396 & 295.4 & 0.99 & 71.18 & 1.80 & 58.0 & 136.4 \\
297.2 & 1.20 & 0.251 & 294.8 & 1.00 & 84.65 & 2.14 & 57.9 & 135.9 \\
297.2 & 1.60 & 0.349 & 296.8 & 1.00 & 81.62 & 2.07 & 57.9 & 135.6 \\
300.1 & 1.69 & 0.281 & 296.1 & 0.99 & 106.94 & 2.70 & 57.6 & 135.2 \\
302.1 & 1.77 & 0.251 & 294.8 & 1.00 & 124.70 & 3.14 & 57.5 & 134.6 \\
303.1 & 2.26 & 0.299 & 296.6 & 1.00 & 134.23 & 3.38 & 57.4 & 134.3 \\
308.1 & 2.71 & 0.250 & 296.8 & 1.00 & 192.75 & 4.84 & 57.0 & 133.0 \\
313.2 & 4.04 & 0.251 & 295.2 & 1.00 & 283.28 & 7.11 & 56.6 & 131.9 \\
\hline
\end{tabular}

${ }^{a}$ Saturation temperature $(u(T)=0.1 \mathrm{~K})$.

${ }^{b}$ Mass of transferred sample condensed at $T=243 \mathrm{~K}$.

${ }^{c}$ Volume of nitrogen $\left(u(V)=0.005 \mathrm{dm}^{3}\right)$ used to transfer $m(u(m)=0.0001 \mathrm{~g})$ of the sample.

${ }^{d} T_{\mathrm{a}}$ is the temperature of the soap bubble meter used for measurement of the gas flow.

${ }^{e}$ Vapour pressure at temperature $T$, calculated from the $m$ and the residual vapour pressure at the condensation temperature calculated by an iteration procedure.

${ }^{f}$ Uncertainties were calculated with $u\left(p_{i} / \mathrm{Pa}\right)=0.005+0.025\left(p_{i} / \mathrm{Pa}\right)$ for pressures below $5 \mathrm{~Pa}$ and with $u\left(p_{i} / \mathrm{Pa}\right)=$ $0.025+0.025\left(p_{i} / \mathrm{Pa}\right)$ for pressures from 5 to $3000 \mathrm{~Pa}$. The uncertainties for $T, V, p, m$, are standard uncertainties with 0.683 confidence level. Uncertainties of the sublimation/vaporization enthalpies $U\left(\Delta_{\mathrm{cr}, \mathrm{l}}^{\mathrm{g}} H_{\mathrm{m}}^{\mathrm{o}}\right)$ are the expanded uncertainty ( 0.95 level of confidence, $\mathrm{k}=2$ ) and include uncertainties from transpiration experimental conditions, uncertainties of vapour pressure, uncertainties from fitting equation, and uncertainties from temperature adjustment to $T=298.15 \mathrm{~K}$ [S2-S4]. 


\section{Combustion calorimetry [S5,S6]}

The liquid samples were encapsulated in small polyethylene ampoules. The solid samples were pressed in pellets. All weightings were performed by using a microbalance with $10^{-6} \mathrm{~g}$ resolution. The bomb was not pre-purged with $\mathrm{O}_{2}$. Test experiments with and without purging with $\mathrm{O}_{2}$ showed results consistent within the experimental uncertainty. Samples were ignited at 3.04 MPa initial oxygen pressure adjusted to $298.15 \mathrm{~K}$. The combustion products were examined for carbon monoxide (Dräger tube) and unburned carbon, but neither was detected. The energy equivalent of the calorimeter $\varepsilon_{\text {calor }}$ was determined with a standard reference sample of benzoic acid (sample SRM 39j, NIST). Correction for nitric acid $\left(\mathrm{HNO}_{3}\right)$ formation was based on titration with $0.1 \mathrm{~mol} \cdot \mathrm{dm}^{-3} \mathrm{NaOH}(\mathrm{aq})$. Auxiliary data required for the reduction are presented in Table S3.

Table S4 Formula, density $\rho(T=293 \mathrm{~K})$, and massic heat capacity $c_{p}(T=298.15 \mathrm{~K})$, of the materials used in the present study. ${ }^{\text {a }}$

\begin{tabular}{|c|c|c|c|}
\hline \multirow[t]{2}{*}{ Compounds } & Formula & $\rho$ & $\mathrm{C}_{p}^{\mathrm{b}}$ \\
\hline & & $\mathrm{g} \cdot \mathrm{cm}^{-3}$ & $\mathrm{~J} \cdot \mathrm{K}^{-1} \mathrm{~g}^{-1}$ \\
\hline indole (cr) & $\mathrm{C}_{8} \mathrm{H}_{7} \mathrm{~N}$ & 1.19[72go] & 1.39 \\
\hline indoline (liq) & $\mathrm{C}_{8} \mathrm{H}_{9} \mathrm{~N}$ & $1.06[\mathrm{SA}]$ & 1.84 \\
\hline 8H-indole (liq) & $\mathrm{C}_{8} \mathrm{H}_{15} \mathrm{~N}$ & $1.07[12 \mathrm{br}]$ & 1.94 \\
\hline 2-methyl-indole (cr) & $\mathrm{C}_{9} \mathrm{H}_{9} \mathrm{~N}$ & 1.07 [18ch] & 1.37 \\
\hline 2-methyl-indoline (liq) & $\mathrm{C}_{9} \mathrm{H}_{11} \mathrm{~N}$ & $0.99^{\mathrm{c}}$ & 1.89 \\
\hline 2-methyl-8H-indole (liq) & $\mathrm{C}_{9} \mathrm{H}_{17} \mathrm{~N}$ & $0.89^{\mathrm{c}}$ & 1.91 \\
\hline polyethylene $^{\mathrm{c}}$ & $\mathrm{CH}_{1.93}$ & 0.92 & 2.53 \\
\hline cotton ${ }^{\mathrm{c}}$ & $\mathrm{CH}_{1.774} \mathrm{O}_{0.887}$ & 1.50 & 1.67 \\
\hline
\end{tabular}

${ }^{\mathrm{a}}$ Data for density and specific heat capacity of auxiliary materials are from our previous work [99ver]: specific energy of combustion $\Delta_{\mathrm{c}} u^{\circ}$ (cotton) $=-16945.2 \mathrm{~J} \cdot \mathrm{g}^{-1} ; u\left(\Delta_{\mathrm{c}} u^{\circ}\right)=4.2 \mathrm{~J} \cdot \mathrm{g}^{-1}$. The specific energy of combustion $\Delta_{\mathrm{c}} u^{\circ}$ (polyethylene) $=-46357.3 \mathrm{~J} \cdot \mathrm{g}^{-1} ; u\left(\Delta_{\mathrm{c}} u^{\circ}\right)=3.6 \mathrm{~J} \cdot \mathrm{g}^{-1}$ was derived from ten combustion experiments performed in this work. The standard uncertainties are reported for the specific energies of combustion.

${ }^{\text {c } C a l c u l a t e d ~ u s i n g ~ a t ~} 293 \mathrm{~K}$ Advanced Chemistry Development (ACD/Labs) Software V11.02 (C) 1994-2020 ACD/Labs) with uncertainty $\pm 0.06 \mathrm{~g} / \mathrm{cm}^{3}$ 
TABLE S5 Results for typical combustion experiments at $T=298.15 \mathrm{~K}\left(\mathrm{p}^{\circ}=0.1 \mathrm{MPa}\right)^{\mathrm{a}}$

\begin{tabular}{lllllll}
\hline & indole & indoline & 8H-indole & 2-Me-indole & 2-Me-indoline & 2-Me-8H-indole \\
\hline $\mathrm{m}$ (substance) /g & 0.306886 & 0.343793 & 0.304871 & 0.439951 & 0.272299 & 0.206533 \\
$\mathrm{~m}^{\prime}($ cotton) $/ \mathrm{g}$ & 0.002179 & 0.002165 & 0.002289 & 0.002717 & 0.002313 & 0.002411 \\
$\mathrm{~m}^{\prime}($ polyethylene)/g & 0.237376 & 0.218594 & 0.253545 & - & 0.341354 & 0.371671 \\
$T^{\mathrm{i}}$ & 298.14613 & 298.14697 & 298.12980 & 298.14910 & 298.15741 & 298.13478 \\
$\mathrm{~T}^{\mathrm{f}}$ & 299.76760 & 299.76241 & 299.82245 & 299.32132 & 298.15741 & 299.92875 \\
$\Delta \mathrm{T}_{\mathrm{c}} / \mathrm{K}$ & 1.49562 & 1.56304 & 1.64719 & 1.10527 & 1.78026 & 1.74863 \\
$\left(\varepsilon_{\text {calor }}\right) \cdot\left(-\Delta \mathrm{T}_{\mathrm{c}}\right) / \mathrm{J}$ & -22136.75 & -23134.65 & -24380.14 & -16359.13 & -26349.68 & -25881.49 \\
$\left(\varepsilon_{\text {cont }}\right) \cdot\left(-\Delta \mathrm{T}_{\mathrm{c}}\right) / \mathrm{J}$ & -23.60 & -25.90 & -27.62 & -16.64 & -30.06 & -29.44 \\
$\Delta \mathrm{U}_{\mathrm{decomp}} \mathrm{HNO}_{3} / \mathrm{J}$ & 28.67 & 29.27 & 26.28 & 26.88 & 25.68 & 22.10 \\
$\Delta \mathrm{U}_{\text {corr }} / \mathrm{J}$ & 9.77 & 9.03 & 7.24 & 8.48 & 9.50 & 7.84 \\
$-\mathrm{m}^{\prime} \cdot \Delta_{\mathrm{c}} \mathrm{u}^{\prime} / \mathrm{J}$ & 36.92 & 36.69 & 38.79 & 46.04 & 39.19 & 40.85 \\
$-\mathrm{m}^{\prime \prime} \Delta_{\mathrm{c}} \mathrm{u} / \mathrm{J}$ & 11004.13 & 10133.43 & 11753.66 & - & 15824.25 & 17229.66 \\
$\Delta_{\mathrm{c}} \mathrm{u}^{\circ} /\left(\mathrm{J} \cdot \mathrm{g}^{-1}\right)$ & -36128.4 & -37674.2 & -41269.2 & -37036.8 & -38491.2 & -41690.9 \\
\hline
\end{tabular}

${ }^{a}$ Results are referenced to $T=298.15 \mathrm{~K}\left(p^{\circ}=0.1 \mathrm{MPa}\right)$. The definition of the symbols assigned according to ref. [56hub,79olo] as follows: $m$ (substance), $m^{\prime}$ (cotton) and $m^{\prime \prime}$ (polyethylene) are, respectively, the mass of compound burnt, the mass of fuse (cotton) and auxiliary polyethylene used in each experiment, masses were corrected for buoyancy; $V($ bomb $)=0.32 \mathrm{dm}^{3}$ is the internal volume of the calorimetric bomb; $p^{\mathrm{i}}$ (gas) $=3.04 \mathrm{MPa}$ is the initial oxygen pressure in the bomb; $m^{\mathrm{i}}\left(\mathrm{H}_{2} \mathrm{O}\right)=1.00 \mathrm{~g}$ is the mass of water added to the bomb for dissolution of combustion gases; $\varepsilon_{\text {calor }}=(14801.05 \pm 1.0) \mathrm{J} \cdot \mathrm{K}^{-1}$, uncertainty for the energy equivalent is expressed as the standard uncertainty; $\Delta T^{\mathrm{c}}=T^{\mathrm{f}}-T^{\mathrm{i}}+\Delta T_{\text {corr }}$ is the corrected temperature rise from initial temperature $T^{\mathrm{i}}$ to final temperature $T^{\text {f }}$, with the correction $\Delta T_{\text {corr }}$ for heat exchange during the experiment; $\varepsilon_{\text {cont }}$ is the energy equivalents of the bomb contents in their initial $\varepsilon_{\text {cont }}^{\mathrm{i}}$ and final states $\varepsilon_{\text {cont }}^{\mathrm{f}}$, the contribution for the bomb content is calculated with ( $\left.\varepsilon_{\text {cont }}\right) \cdot(-$ $\left.\Delta T_{\mathrm{c}}\right)=\left(\varepsilon_{\text {cont }}^{\mathrm{i}}\right) \cdot\left(T^{\mathrm{i}}-298.15\right)+\left(\varepsilon_{\text {cont }}^{\mathrm{f}}\right) \cdot\left(298.15-T^{\mathrm{f}}+\Delta T_{\text {corr. }}\right) . \Delta U_{\text {decomp }} \mathrm{HNO}_{3}$ is the energy correction for the nitric acid formation. $\Delta U_{\text {corr }}$ is the correction to standard states. Auxiliary data are given in Table S4.

\section{Enthalpy of fusion measurements [S1]}

Thermal behavior of crystalline sample of indole and 2-methyl-indole including melting temperatures and enthalpies of fusion was studied with a commercial Perkin-Elmer DSC-1. A sample was placed in the standard non-pinned aluminium pan of $40 \mu \mathrm{l}$ volume. Pan and sample were weighted with a microbalance with the standard uncertainty of $5 \cdot 10^{-6} \mathrm{~g}$. In the first DSC run the sample was heated with a rate $10 \mathrm{~K} \cdot \mathrm{min}^{-1}$ to $398 \mathrm{~K}(\sim 30 \mathrm{~K}$ above melting temperature provided by supplier) and then cooled down to $298 \mathrm{~K}$, also with the rate $10 \mathrm{~K} \cdot \mathrm{min}^{-1}$. Such procedure provided sufficient contact between the sample and the bottom of pan. The DSC experiments were repeated three times. The calibration of the DSC was checked with melting behaviour of reference indium sample. The twice standard deviation of the enthalpy of fusion in the test measurements for reference compound was $\pm 0.3 \mathrm{~kJ} \cdot \mathrm{mol}^{-1}$ and $\pm 0.3 \mathrm{~K}$ for the melting temperature. Uncertainties of the enthalpy of fusion values are expressed as expanded uncertainties (at a level of confidence of $0.95, \mathrm{k}=2$ ). They include uncertainties from fusion experiment and calibration. Details are reported elsewhere [S1].

As a rule, thermochemical calculations are commonly performed at the reference temperature $T=298.15 \mathrm{~K}$. The adjustment of $\Delta_{\mathrm{cr}}^{\mathrm{1}} H_{\mathrm{m}}^{\mathrm{o}}\left(T_{\text {fus }}\right)$ was performed with help of the equation [17acr]:

$\Delta_{\mathrm{cr}}^{\mathrm{l}} H_{m}^{\mathrm{o}}(298.15 \mathrm{~K}) /\left(\mathrm{J} \cdot \mathrm{mol}^{-1}\right)=\Delta_{\mathrm{cr}}^{\mathrm{l}} H_{m}^{\mathrm{o}}\left(T_{\mathrm{fus}} / \mathrm{K}\right)-\left(\Delta_{\mathrm{cr}}^{\mathrm{g}} C_{p, m}^{\mathrm{o}}-\Delta_{1}^{\mathrm{g}} C_{p, m}^{\mathrm{o}}\right) \times\left[\left(T_{\mathrm{fu}} / \mathrm{K}\right)-298.15 \mathrm{~K}\right]$ where $\Delta_{c r}^{g} C_{p, m}^{o}$ and $\Delta_{1}^{g} C_{p, m}^{o}$ were taken from Table S2. With this adjustment, the molar enthalpies of fusion, $\Delta_{\mathrm{cr}}^{1} H_{m}^{o}(298.15 \mathrm{~K})$ were calculated. Uncertainties in the temperature adjustment of fusion enthalpy from $T_{\text {fus }}$ to the reference temperature were estimated to account with $30 \%$ to the total adjustment [14gob]. 


\section{Computational Details}

Different conformers are generated by systematically or randomly altering the torsional angles in the molecule. The geometries of conformers were optimized at the HF/6-31G(d,p) level [71dit], and the resulting structures were confirmed as minima through harmonic frequency calculations. After that, a full geometry optimizations were carried out at the B3LYP/6$31 \mathrm{G}(\mathrm{d}, \mathrm{p})$ level [05iri]. The corresponding harmonic vibrational frequencies were evaluated at the same level of theory to confirm that the optimized structures found correspond to potential energy minima and to evaluate the corresponding zero-point vibrational energies, ZPE, and the thermal corrections at $298 \mathrm{~K}$. We used the G4, G3MP2 and CBS-APNO methods for calculations of enthalpies $\mathrm{H}_{298}$ of the most stable conformers of substituted benzaldehydes. Calculations were performed under assumption "rigid rotator"-"harmonic oscillator". The $H_{298}$ values were evaluated according to standard thermodynamic procedures [76McQ]. 


\section{Correlations of vaporization enthalpies with gas-chromatographic indices.}

The Kovats's retention index, $J_{\mathrm{x}}$, is calculated with help of retention times of $n$-alkanes used as standards [58kov]:

$$
J_{x}=\frac{\lg \left(t_{x}\right)-\lg \left(t_{N}\right)}{\lg \left(t_{N+1}\right)-\lg \left(t_{N}\right)} \times 100+100 N
$$

where $x$ refers to the adjusted retention time $t, N$ is the number of carbon atoms of the $n$-alkane eluting before, and $(N+1)$ is the number of carbon atoms of the $n$-alkane eluting after the peak of interest. According to the established GC procedure, all retention times are corrected for the "dead" retention time (the retention time of a non-retained component: dichloromethane or methane) adjusted from the retention times of the homologues linear aliphatic hydrocarbons [58kov]. Thus, the retention time $t_{x}$ of the compound of interest $x$ is encompassed by retention times of the two $n$-alkanes. The literature data on the Kovats's retention index, $J_{\mathrm{x}}$, for substituted cyclic compounds parent to indole derivatives available in the literature were taken for correlation with their vaporisation enthalpies.

Table S6 Correlation of vaporization enthalpies $\Delta_{\mathrm{l}}^{\mathrm{g}} H_{\mathrm{m}}^{\mathrm{o}}(298.15 \mathrm{~K})$ of cyclic alkanes and aromatics with their Kovats's indices $J_{x}$.

\begin{tabular}{|l|c|l|c|c|}
\hline & $J_{X}{ }^{\mathrm{a}}$ & \multicolumn{1}{|c|}{$\Delta_{\mathrm{l}}^{\mathrm{g}} H_{\mathrm{m}}^{\mathrm{o}}(298.15 \mathrm{~K})_{\exp }$} & $\Delta_{\mathrm{l}}^{\mathrm{g}} H_{\mathrm{m}}^{\mathrm{o}}(298.15 \mathrm{~K})_{\mathrm{calc}^{\mathrm{b}}}$ & $\Delta^{\mathrm{c}}$ \\
\hline cyclopentane & & \multicolumn{1}{c|}{$\mathrm{kJ} \cdot \mathrm{mol}^{-1}$} & 28.7 & 0.0 \\
\hline methyl-cyclopentane & 568 & $28.7 \pm 0.1[\mathrm{M} 85]$ & 31.6 & 0.2 \\
\hline indane & 634 & $31.8 \pm 0.1[\mathrm{M} 85]$ & 48.5 & 0.5 \\
\hline 2-methyl-indane & 1015 & $49.0 \pm 0.2[11$ ver-eme_1] & $\mathbf{5 1 . 6 \pm 1 . 0}$ & \\
\hline indene & 1085 & & 49.4 & 0.9 \\
\hline 2-methyl-indene & 1036 & $50.3 \pm 0.2[11$ ver-eme_2] & $\mathbf{5 0 . 8} \pm \mathbf{1 . 0}$ & \\
\hline cis-octahydro-1H-indene & 980 & $46.0 \pm 1.3[\mathrm{P} 86]$ & 46.9 & -0.9 \\
\hline trans-octahydro-1H-indene & 950 & $44.7 \pm 1.3[\mathrm{P} 86]$ & 45.6 & -0.9 \\
\hline pyrrolidine & & $37.5 \pm 0.2[\mathrm{P} 86]$ & & \\
\hline 2-methyl-pyrrolidine & & $40.6 \pm 1.0[\mathrm{P} 86]$ & & \\
\hline
\end{tabular}

${ }^{a}$ Data on standard non-polar columns from [pub].

${ }^{\mathrm{b}}$ Calculated using the following equation:

$$
\Delta_{\mathrm{l}}^{\mathrm{g}} H_{\mathrm{m}}^{\mathrm{o}}(298.15 \mathrm{~K}) /\left(\mathrm{kJ} \cdot \mathrm{mol}^{-1}\right)=3.5+0.0443 \times J_{x} \text { with }\left(R^{2}=0.993\right)
$$

${ }^{\mathrm{c}}$ Difference between experimental and calculated by Eq. (S4) values.

It is known, that the $\Delta_{1}^{\mathrm{g}} H_{\mathrm{m}}^{\mathrm{o}}(298.15 \mathrm{~K})$-values correlate linearly with Kovats`s indices in various homologous series of alkylbenzenes, alkanes, aliphatic ethers, alcohols, or in a series of structurally similar compounds [99ver]. As expected, the $\Delta_{1}^{\mathrm{g}} H_{\mathrm{m}}^{\mathrm{o}}(298.15 \mathrm{~K})$-values correlated linearly with $J_{x}$ values for each of the selected sets of compounds

$$
\Delta_{\mathrm{l}}^{\mathrm{g}} H_{\mathrm{m}}^{\mathrm{o}}(298.15 \mathrm{~K}) /\left(\mathrm{kJ} \cdot \mathrm{mol}^{-1}\right)=3.5+0.0443 \times J_{x} \text { with }\left(R^{2}=0.993\right)
$$

The results of the correlations with Kovats's indices are in a good agreement with those of the literature data (see Table S6). It can be seen from Table S6, that differences between experimental and calculated according to Eq. (4) values are mostly below $1 \mathrm{~kJ} \cdot \mathrm{mol}^{-1}$. Hence, the uncertainties of vaporization enthalpies values estimated from the $\Delta_{\mathrm{l}}^{\mathrm{g}} H_{\mathrm{m}}^{\mathrm{o}}(298.15 \mathrm{~K})-J_{X}$ correlations are assessed to be $\pm 1.0 \mathrm{~kJ} \cdot \mathrm{mol}^{-1}$. 
Table S7. Reactions and reaction enthalpies calculated by using quantum-chemical methods for indole

1.1<smiles>CCC(C)c1ccc2c(c1)C[CH+]=C2</smiles>

1.2<smiles>CCNCCCc1ccc2c(c1)C=[C+]C2</smiles>

1.3<smiles>C=CC1=C[CH+]C=C1</smiles>

1.4<smiles>C1=CCCC1</smiles>

1.5<smiles>C=NC(C)C1=C[CH+]C=C1</smiles> 
The enthalpy of formation of Indole $\Delta_{\mathrm{f}} H_{m}^{0}(\mathrm{~g}, 298.15 \mathrm{~K}), \mathrm{kJ} / \mathrm{mol}$

\begin{tabular}{|l|l|l|l|l|l|l|}
\hline method & (AT) & $\begin{array}{l}\text { Reaction } \\
1.1\end{array}$ & $\begin{array}{l}\text { Reaction } \\
1.2\end{array}$ & $\begin{array}{l}\text { Reaction } \\
1.3\end{array}$ & $\begin{array}{l}\text { Reaction } \\
1.4\end{array}$ & $\begin{array}{l}\text { Reaction } \\
1.5^{*}\end{array}$ \\
\hline G4 & 160,4 & 160,4 & 160,6 & 158,7 & 166,1 & 159,0 \\
\hline G3MP2 & 158,8 & 160,4 & 160,9 & 158,4 & 165,0 & 160,0 \\
\hline $\begin{array}{l}\text { CBS- } \\
\text { APNO }\end{array}$ & & 157,0 & 157,3 & 161,2 & 168,2 & 162,1 \\
\hline
\end{tabular}

* In reaction (1.5) instead of the experimental value $\Delta_{f} H_{298}^{0} \mathrm{~N}$-methyl-methaneimine value was used by G4 (AT) method.

The enthalpies of hypothetical reactions involving Indole $\Delta_{\mathrm{r}} H_{m}^{0}(\mathrm{~g}, 298.15 \mathrm{~K})$, $\mathrm{kJ} / \mathrm{mol}$

\begin{tabular}{|l|l|l|l|l|l|}
\hline$\Delta_{\mathrm{r}} H_{m}^{\text {o }}(\mathrm{g}, 298.15 \mathrm{~K})$ & Reaction 1.1 & Reaction 1.2 & Reaction 1.3 & Reaction 1.4 & Reaction 1.5 \\
\hline G4 & 86,4 & 78,9 & $-20,3$ & $-31,0$ & $-43,1$ \\
\hline G3MP2 & 86,4 & 78,6 & $-20,0$ & $-29,9$ & $-44,2$ \\
\hline CBS-APNO & 89,8 & 82,2 & $-22,8$ & $-33,1$ & $-46,3$ \\
\hline
\end{tabular}


Table S8. Reactions and reaction enthalpies calculated by using quantum-chemical methods for indoline

2.1<smiles>CCC1C[CH+]N[C@H]1CC</smiles>

2.2<smiles>[AsH3]CC1C[CH+]NC1C=C1[CH+]CCC1</smiles>

2.3<smiles>c1ccc2c(c1)CCN2</smiles><smiles>CNCC1CCCCC1</smiles>

15<smiles>Nc1ccccc1</smiles>

13

2.4<smiles>c1ccc2c(c1)CCN2</smiles>

$+\mathrm{H}_{3} \mathrm{C}-\mathrm{NH}-\mathrm{CH}_{2}-\mathrm{CH}_{3}$<smiles>Cc1ccc(N)cc1</smiles>

2.5<smiles>C=C(C)C1C[C+]=CC1</smiles> 
The enthalpy of formation of Indoline $\Delta_{\mathrm{f}} H_{m}^{\mathrm{o}}(\mathrm{g}, 298.15 \mathrm{~K}), \mathrm{kJ} / \mathrm{mol}$

\begin{tabular}{|l|l|l|l|l|l|l|}
\hline method & $(\mathrm{AT})$ & $\begin{array}{l}\text { Reaction } \\
2.1\end{array}$ & $\begin{array}{l}\text { Reaction } \\
2.2\end{array}$ & $\begin{array}{l}\text { Reaction } \\
2.3\end{array}$ & $\begin{array}{l}\text { Reaction } \\
2.4\end{array}$ & $\begin{array}{l}\text { Reaction } \\
2.5\end{array}$ \\
\hline G4 & 117,6 & 115,1 & 121,6 & 117,8 & 118,4 & 113,5 \\
\hline G3MP2 & 116,0 & 115,4 & 120,4 & 119,1 & 118,5 & 114,9 \\
\hline $\begin{array}{l}\text { CBS- } \\
\text { APNO }\end{array}$ & & 114,2 & 120,7 & 118,9 & 119,4 & 114,6 \\
\hline
\end{tabular}

The enthalpies of hypothetical reactions involving Indoline $\Delta_{\mathrm{r}} H_{m}^{0}(\mathrm{~g}, 298.15 \mathrm{~K})$, $\mathbf{k J} / \mathbf{m o l}$

\begin{tabular}{|l|l|l|l|l|l|}
\hline$\Delta_{\mathrm{r}} H_{m}^{\mathrm{o}}(\mathrm{g}, 298.15$ & Reaction & Reaction & Reaction & Reaction & Reaction \\
$\mathrm{K})$ & 2.1 & 2.2 & 2.3 & 2.4 & 2.5 \\
\hline G4 & 47,9 & 11,7 & $-15,5$ & $-18,0$ & $-12,5$ \\
\hline G3MP2 & 47,6 & 12,9 & $-16,8$ & $-18,1$ & $-13,9$ \\
\hline CBS-APNO & 48,8 & 12,6 & $-16,6$ & $-19,0$ & $-13,6$ \\
\hline
\end{tabular}


Table S9. Reactions and reaction enthalpies calculated by using quantum-chemical methods for $8 \mathrm{H}$-indole

3.1<smiles>CCC1C[CH+]NC1</smiles>

3.2<smiles>CNC(C)C1CC[C@@H](C)C1</smiles>

3.3<smiles>[CH+]1CCC2CCCCC2C1</smiles>

3.4<smiles>C1CCC2NCCC2C1</smiles>

$+\mathrm{H}_{2} \mathrm{C}=\mathrm{CH}-\mathrm{CH}_{3}$<smiles>CC1CC=CCC1</smiles>

10

19 
The enthalpy of formation of H8-Indole $\Delta_{\mathrm{f}} H_{m}^{\mathbf{0}}(\mathrm{g}, 298.15 \mathrm{~K}), \mathrm{kJ} / \mathrm{mol}$

\begin{tabular}{|l|l|l|l|l|l|l|}
\hline метод & (АT) & $\begin{array}{l}\text { Reaction } \\
\text { Reaction }\end{array}$ & $\begin{array}{l}\text { Reaction } \\
3.1\end{array}$ & $\begin{array}{l}\text { Reaction } \\
3.2\end{array}$ & $\begin{array}{l}\text { Reaction } \\
3.3\end{array}$ \\
\hline G4 & $-63,5$ & $-67,5$ & $-63,6$ & $-59,9$ & $-61,4$ & $-68,0$ \\
\hline G3MP2 & $-60,5$ & $-66,7$ & $-61,6$ & $-60,4$ & $-62,1$ & $-65,8$ \\
\hline CBS- & & $-65,4$ & $-61,0$ & $-60,2$ & $-61,5$ & $-65,3$ \\
APNO & & & & & & \\
\hline
\end{tabular}

a - from a reaction involving cis-octahydro-1-indene

$\mathrm{b}$ - from a reaction involving trans-octahydro-1-indene

The enthalpies of hypothetical reactions involvingH8-Indole, $\Delta_{\mathrm{r}} H_{m}^{0}(\mathrm{~g}, 298.15 \mathrm{~K})$

$\mathbf{k J} / \mathbf{m o l}$

\begin{tabular}{|l|l|l|l|l|l|}
\hline$\Delta_{\mathrm{r}} H_{m}^{\mathrm{o}}(\mathrm{g}, 298.15 \mathrm{~K})$ & Reaction & Reaction & Reaction & Reaction & Reaction \\
& 3.1 & 3.2 & $3.3^{\mathrm{a}}$ & $3.3^{\mathrm{b}}$ & 3.4 \\
\hline G4 & 24,5 & $-25,0$ & 5,8 & 2,9 & $-21,9$ \\
\hline G3MP2 & 23,7 & $-27,0$ & 6,3 & 3,6 & $-24,1$ \\
\hline CBS-APNO & 22,4 & $-27,6$ & 6,1 & 3,0 & $-24,6$ \\
\hline
\end{tabular}

a - from a reaction involving cis-octahydro-1-indene

$\mathrm{b}$ - from a reaction involving trans-octahydro-1-indene 
Table S10. Reactions and reaction enthalpies calculated by using quantum-chemical methods for 2-methyl-indole

4.1<smiles>C=CC1=CC=[C+]N1</smiles>

4.2<smiles>CCCNCCC</smiles>

4.3<smiles>Cc1cc2ccccc2[nH]1</smiles>

4.4<smiles>C=N/C=C1\[C+]=C[C+](Cc2cc3ccccc3[nH]2)C1</smiles>

4.5<smiles>CCCc1ccc2c(c1)CC=[C+]C2</smiles>

4.6<smiles>CC[C+](C)C1CCC(C)N1</smiles> 
The enthalpy of formation of2-Methyl-Indole $\Delta_{\mathrm{f}} H_{m}^{0}(\mathrm{~g}, 298.15 \mathrm{~K}), \mathrm{kJ} / \mathrm{mol}$

\begin{tabular}{|l|l|l|l|l|l|l|l|}
\hline метод & (AT) & $\begin{array}{l}\text { Reaction } \\
4.1\end{array}$ & $\begin{array}{l}\text { Reaction } \\
4.2\end{array}$ & $\begin{array}{l}\text { Reaction } \\
4.3\end{array}$ & $\begin{array}{l}\text { Reaction } \\
4.4\end{array}$ & $\begin{array}{l}\text { Reaction } \\
4.5\end{array}$ & $\begin{array}{l}\text { Reaction } \\
4.6\end{array}$ \\
\hline G4 & 120,2 & 119,6 & 120,6 & 127,8 & 119,7 & 120,6 & 117,2 \\
\hline G3MP2 & 118,9 & 119,0 & 121,4 & 127,1 & 120,4 & 121,1 & 118,4 \\
\hline $\begin{array}{l}\text { CBS- } \\
\text { APNO }\end{array}$ & & 121,0 & 116,6 & 128,7 & 122,2 & 115,2 & 115,2 \\
\hline
\end{tabular}

The enthalpies of hypothetical reactions involving2-Methyl-Indole $\Delta_{\mathrm{r}} H_{m}^{0}(\mathrm{~g}, 298.15$ K), kJ/mol

\begin{tabular}{|l|l|l|l|l|l|l|}
\hline$\Delta_{\mathrm{r}} H_{m}^{\mathrm{o}}(\mathrm{g}, 298.15 \mathrm{~K})$ & Reaction & Reaction & Reaction & Reaction & Reaction & Reaction \\
& 4.1 & 4.2 & 4.3 & 4.4 & 4.5 & 4.6 \\
\hline G4 & $-13,4$ & 98,0 & $-27,4$ & $-34,0$ & 103,9 & 73,3 \\
\hline G3MP2 & $-12,8$ & 97,2 & $-26,7$ & $-34,7$ & 103,4 & 72,1 \\
\hline CBS-APNO & $-14,8$ & 102,0 & $-28,3$ & $-36,5$ & 109,3 & 75,3 \\
\hline
\end{tabular}


Table S11. Reactions and reaction enthalpies calculated by using quantum-chemical methods for 2-methyl-indoline

5.1<smiles>CCC1CCC(C)N1</smiles>

5.2<smiles>CC(C)C1CCCN1</smiles>

5.3<smiles>CC1CCC(CC=C2Cc3ccccc3N2)N1</smiles>

5.4<smiles>Cc1ccc(N)cc1</smiles>

5.5<smiles>CC1Cc2ccccc2N1</smiles><smiles>C1CCCC1</smiles>

16<smiles>CC1CCC(C)N1</smiles>

25<smiles>c1ccc2c(c1)CCC2</smiles>

11

5.6<smiles>CC1=CC(CC=CC2Cc3ccccc3N2)CC1</smiles> 
The enthalpy of formation of2-Methyl-Indoline $\Delta_{\mathrm{f}} H_{m}^{0}(\mathrm{~g}, 298.15 \mathrm{~K}), \mathrm{kJ} / \mathrm{mol}$

\begin{tabular}{|l|l|l|l|l|l|l|l|}
\hline method & (AT) & $\begin{array}{l}\text { Reaction } \\
\text { Geaction }\end{array}$ & $\begin{array}{l}\text { Reaction } \\
5.2\end{array}$ & 5.3 & $\begin{array}{l}\text { Reaction } \\
5.4\end{array}$ & $\begin{array}{l}\text { Reaction } \\
5.5\end{array}$ & $\begin{array}{l}\text { Reaction } \\
5.6\end{array}$ \\
\hline G4 & 79,4 & 77,3 & 78,0 & 80,1 & 80,7 & 84,2 & 76,8 \\
\hline G3MP2 & 78,0 & 77,9 & 77,9 & 81,6 & 81,6 & 83,3 & 77,6 \\
\hline $\begin{array}{l}\text { CBS- } \\
\text { APNO }\end{array}$ & & 76,1 & 77,1 & 80,9 & 84,2 & 83,1 & 78,4 \\
\hline
\end{tabular}

The enthalpies of hypothetical reactions involving2-Methyl-Indoline $\Delta_{\mathrm{r}} H_{m}^{0}$ (g, $298.15 \mathrm{~K}), \mathrm{kJ} / \mathbf{m o l}$

\begin{tabular}{|l|l|l|l|l|l|l|}
\hline$\Delta_{\mathrm{r}} H_{m}^{\mathrm{o}}(\mathrm{g}$, & Reaction & Reaction & Reaction & Reaction & Reaction & Reaction \\
$298.15 \mathrm{~K})$ & 5.1 & 5.2 & 5.3 & 5.4 & 5.5 & 5.6 \\
\hline G4 & 48,2 & 52,8 & $-15,3$ & $-46,0$ & 12,0 & $-13,5$ \\
\hline G3MP2 & 47,6 & 52,9 & $-16,8$ & $-46,9$ & 12,9 & $-14,3$ \\
\hline CBS-APNO & 49,4 & 53,7 & $-16,1$ & $-49,5$ & 13,1 & $-15,1$ \\
\hline
\end{tabular}


Table S12. Reactions and reaction enthalpies calculated by using quantum-chemical methods for 2-methyl-8H-indole

6.1<smiles>C[C@@H]1CC2CCCCC2N1</smiles><smiles>CC</smiles><smiles>CC1CCC(C)N1</smiles>

25<smiles>C[C@@H]1CC2CCCCC2N1</smiles><smiles>CNC</smiles>

6.3<smiles>C[C@H]1CC2CCCCC2N1</smiles><smiles>C1CCCC1</smiles>

16<smiles>CCC1CCC(C)N1</smiles>

25<smiles>C1CCC2CCCC2C1</smiles>

20

6.4<smiles>C[C@H]1CC2CCCCC2N1</smiles><smiles>C=CC</smiles><smiles>CC1=CCC(C)C1</smiles>

26<smiles>NC1CCCCC1</smiles>

19

The enthalpy of formation of 8H-2-Methyl-Indole $\Delta_{\mathrm{f}} H_{m}^{\mathbf{0}}(\mathrm{g}, 298.15 \mathrm{~K}), \mathrm{kJ} / \mathrm{mol}$

\begin{tabular}{|l|l|l|l|l|l|l|}
\hline method & (AT) & $\begin{array}{l}\text { Reaction } \\
6.1\end{array}$ & $\begin{array}{l}\text { Reaction } \\
6.2\end{array}$ & $\begin{array}{l}\text { Reaction 6.3 } \\
\text { a }\end{array}$ & $\begin{array}{l}\text { Reaction 6.3 } \\
\text { b }\end{array}$ & $\begin{array}{l}\text { Reaction } \\
6.4\end{array}$ \\
\hline G4 & $-100,4$ & $-104,0$ & $-100,1$ & $-98,0$ & $-96,5$ & $-103,4$ \\
\hline G3MP2 & $-97,3$ & $-103,0$ & $-97,9$ & $-98,3$ & $-96,7$ & $-101,9$ \\
\hline $\begin{array}{l}\text { CBS- } \\
\text { APNO }\end{array}$ & & $-102,2$ & $-97,7$ & $-98,2$ & $-97,0$ & $-100,3$ \\
\hline
\end{tabular}

a - from a reaction involving trans-octahydro-1-indene

$\mathrm{b}$ - from a reaction involving cis-octahydro-1-indene 
The enthalpies of hypothetical reactions involving 8H-2-Methyl-Indole $\Delta_{\mathrm{r}} H_{m}^{0}(\mathrm{~g}$, 298.15 K), $\mathrm{kJ} / \mathbf{m o l}$

\begin{tabular}{|l|l|l|l|l|l|}
\hline$\Delta_{\mathrm{r}} H_{m}^{\mathrm{o}}(\mathrm{g}, 298.15 \mathrm{~K})$ & Reaction & Reaction & Reaction & Reaction & Reaction \\
& 6.1 & 6.2 & $6.3^{\mathrm{a}}$ & $6.3^{\mathrm{b}}$ & 6.4 \\
\hline G4 & 23,5 & $-26,0$ & 2,0 & 4,9 & $-24,2$ \\
\hline G3MP2 & 22,5 & $-28,2$ & 2,3 & 5,1 & $-25,7$ \\
\hline CBS-APNO & 21,7 & $-28,4$ & 2,2 & 5,4 & $-27,3$ \\
\hline
\end{tabular}

a - from a reaction involving trans-octahydro-1-indene

$\mathrm{b}$ - from a reaction involving cis-octahydro-1-indene

Table S13. Reference values for $\Delta_{\mathrm{f}} H_{m}^{\mathrm{o}}(\mathrm{g}, 298.15 \mathrm{~K})$ used for calculation reaction enthalpies in Tables S7-S12 with help of quantum-chemical methods

\begin{tabular}{|c|c|c|c|c|c|c|}
\hline & structure & CAS & compound & Formula & $\Delta_{\mathrm{f}} H_{m}^{\mathrm{o}}(\mathrm{g}, 298.15 \mathrm{~K})$ & Ref \\
\hline 1 & $\mathrm{CH}_{3}-\mathrm{CH}_{2}-\mathrm{CH}_{3}$ & $\begin{array}{l}74-98-6 \\
\end{array}$ & propane & $\mathrm{C}_{3} \mathrm{H}_{6}$ & $-104.7 \pm 0.5$ & P86 \\
\hline 2 & & $95-13-6$ & indene & $\mathrm{C}_{9} \mathrm{H}_{8}$ & $160.7 \pm 1.3$ & $\begin{array}{l}\text { 11ver- } \\
\text { eme. } 2\end{array}$ \\
\hline 3 & $\mathrm{CH}_{3}-\mathrm{NH}-\mathrm{CH}_{3}$ & $124-40-4$ & dimethylamine & $\mathrm{C}_{2} \mathrm{H}_{7} \mathrm{~N}$ & $-18.6 \pm 0.8$ & P86 \\
\hline 4 & $\mathrm{CH}_{3}-\mathrm{CH}_{2}-\mathrm{CH}_{2}-\mathrm{CH}_{3}$ & $106-97-8$ & butane & $\mathrm{C}_{4} \mathrm{H}_{10}$ & $-125.6 \pm 0.7$ & P86 \\
\hline 5 & & $106-49-0$ & $\begin{array}{l}\text { 4-amino- } \\
\text { toluene }\end{array}$ & $\mathrm{C}_{7} \mathrm{H}_{9} \mathrm{~N}$ & $57.0 \pm 1.3$ & $\begin{array}{l}\text { 05eme- } \\
\text { ver }\end{array}$ \\
\hline 6 & $\mathrm{CH}_{2} \mathrm{NH}_{2} \mathrm{CH}_{2} \mathrm{CH}_{2}$ & $624-78-2$ & N-methyl- & $\mathrm{C}_{3} \mathrm{H}_{0} \mathrm{~N}$ & $-468+20$ & 19dor- \\
\hline 0 & $\mathrm{H}^{-2}$ & $024-/ 8-2$ & ethanamine & $\mathrm{C}_{3 \mathrm{H} 9 \mathrm{~N}}$ & $-46.8 \pm 2.0$ & fil \\
\hline 7 & $\mathrm{H}_{0} \mathrm{C}$ & 74-85-1 & ethene & $\mathrm{C}_{2} \mathrm{H}_{4}$ & $52.5 \pm 0.4$ & P86 \\
\hline 8 & & $109-97-7$ & 1-H-pyrole & $\mathrm{C}_{4} \mathrm{H}_{5} \mathrm{~N}$ & $108.3 \pm 0.4$ & P86 \\
\hline 9 & & $71-43-2$ & benzene & $\mathrm{C}_{6} \mathrm{H}_{6}$ & $82.6 \pm 0.7$ & P86 \\
\hline 10 & & $142-29-0$ & cyclo-pentene & $\mathrm{C}_{5} \mathrm{H}_{8}$ & $33.9 \pm 1.4$ & P86 \\
\hline 11 & & 496-11-7 & indane & $\mathrm{C}_{9} \mathrm{H}_{10}$ & $60.7 \pm 1.8$ & $\begin{array}{l}\text { 11ver- } \\
\text { eme.1 }\end{array}$ \\
\hline 12 & $\mathrm{H}_{2} \mathrm{C}=$ & $1761-67-7$ & $\begin{array}{c}\mathrm{N}-m e t h y l- \\
\text { methanimine }\end{array}$ & $\mathrm{C}_{2} \mathrm{H}_{5} \mathrm{~N}$ & & G4(AT) \\
\hline 13 & & $62-53-3$ & aniline & $\mathrm{C}_{6} \mathrm{H}_{7} \mathrm{~N}$ & $87.1 \pm 1.0$ & P86 \\
\hline 14 & $\mathrm{H}_{3} \mathrm{C}=\mathrm{CH}_{3}$ & $74-84-0$ & ethane & $\mathrm{C}_{2} \mathrm{H}_{6}$ & $-83.8 \pm 0.4$ & P86 \\
\hline
\end{tabular}




\begin{tabular}{|c|c|c|c|c|c|c|}
\hline 15 & & $123-75-1$ & pyrrolidine & $\mathrm{C}_{4} \mathrm{H}_{9} \mathrm{~N}$ & $-3.4 \pm 0.8$ & P86 \\
\hline 16 & & 287-92-3 & cyclopentane & $\mathrm{C}_{5} \mathrm{H}_{10}$ & $-76.4 \pm 0.8$ & P86 \\
\hline 17 & $\mathrm{H}_{2} \mathrm{C}=\mathrm{CH}-\mathrm{CH}_{3}$ & $115-07-1$ & propene & $\mathrm{C}_{3} \mathrm{H}_{6}$ & $20.0 \pm 0.8$ & P86 \\
\hline 18 & & $110-82-7$ & cyclohexane & $\mathrm{C}_{6} \mathrm{H}_{12}$ & $-123.4 \pm 0.8$ & P86 \\
\hline 19 & & 108-91-8 & $\begin{array}{l}\text { cyclohexyl- } \\
\text { amine }\end{array}$ & $\mathrm{C}_{6} \mathrm{H}_{13} \mathrm{~N}$ & $-103.9 \pm 1.3$ & $\begin{array}{l}\text { 15ver- } \\
\text { eme }\end{array}$ \\
\hline 20 & & $4551-51-3$ & $\begin{array}{l}\text { cis-octahydro- } \\
\text { 1H-indene }\end{array}$ & $\mathrm{C}_{9} \mathrm{H}_{16}$ & $-127.1 \pm 2.0$ & P86 \\
\hline 20 & & $3296-50-2$ & $\begin{array}{c}\text { trans-octahydro- } \\
1 \mathrm{H} \text {-indene }\end{array}$ & $\mathrm{C}_{9} \mathrm{H}_{16}$ & $-131.5 \pm 2.2$ & P86 \\
\hline 21 & & $108-88-3$ & toluene & $\mathrm{C}_{7} \mathrm{H}_{8}$ & $50.4 \pm 0.6$ & P86 \\
\hline 22 & & 119-64-2 & tetraline & $\mathrm{C}_{10} \mathrm{H}_{12}$ & $26.0 \pm 2.0$ & P86 \\
\hline 23 & & 612-17-9 & $\begin{array}{l}\text { 1,4-dihydro- } \\
\text { naphtalene }\end{array}$ & $\mathrm{C}_{10} \mathrm{H}_{10}$ & $138.4 \pm 1.6$ & 99ver \\
\hline 24 & & $74-82-8$ & methane & $\mathrm{CH}_{4}$ & $-74.4 \pm 0.4$ & P86 \\
\hline 25 & & 765-38-3 & $\begin{array}{l}\text { 2-methyl- } \\
\text { pyrrolidine }\end{array}$ & $\mathrm{C}_{5} \mathrm{H}_{11} \mathrm{~N}$ & $-40.9 \pm 1.6$ & $\begin{array}{l}\text { 20dor- } \\
\text { fil }\end{array}$ \\
\hline 26 & & $693-89-0$ & $\begin{array}{c}\text { 1-methyl- } \\
\text { cyclopentene }\end{array}$ & $\mathrm{C}_{6} \mathrm{H}_{10}$ & $-3.8 \pm 0.7$ & P86 \\
\hline
\end{tabular}




\section{Computation of the thermodynamic properties for studied compounds in ideal gas state.}

The conformer search was carried out by using Conformer Rotamer Ensemble Sampling Tool (CREST) by Grimmer utilizing metadynamic scan of the chemical compound, conformer and reaction space followed by optimization of the found conformers and rotamers at GFN2-xTB

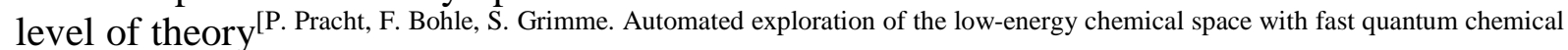
methods. Phys. Chem. Chem. Phys., 2020,22, 7169-7192; S. Grimme. Exploration of Chemical Compound, Conformer, and Reaction Space with Meta-Dynamics Simulations Based on Tight-Binding Quantum Chemical Calculations.J. Chem. Theory Comput. 2019, 15, 5, 28472862].

After the CREST stage, the geometries of all found conformers were further optimized and vibrational frequencies and methyl rotational potentials for molecules with CH3- rotating top were computed using B3LYP hybrid density functional theory with the cc-pvtz(D3BJ) basis set [D. Rappoport, F. Furche, J. Chem. Phys. 133 (2010) 134105, S. Grimme, S. Ehrlich and L. Goerigk, "Effect of the damping function in dispersion corrected density functional theory,” J. Comp. Chem. 32 (2011) 1456-65.] with the help of Gaussian 16 package [Gaussian 16, Revision C.01, M. J. Frisch, G. W. Trucks, H. B. Schlegel, G. E. Scuseria, M. A. Robb, J. R. Cheeseman, G. Scalmani, V. Barone, G. A. Petersson, H. Nakatsuji, X. Li, M. Caricato, A. V. Marenich, J. Bloino, B. G. Janesko, R. Gomperts, B. Mennucci, H. P. Hratchian, J. V. Ortiz, A. F. Izmaylov, J. L. Sonnenberg, D. Williams-Young, F. Ding, F. Lipparini, F. Egidi, J. Goings, B. Peng, A. Petrone, T. Henderson, D. Ranasinghe, V. G. Zakrzewski, J. Gao, N. Rega, G. Zheng, W. Liang, M. Hada, M. Ehara, K. Toyota, R. Fukuda, J. Hasegawa, M. Ishida, T. Nakajima, Y. Honda, O. Kitao, H. Nakai, T. Vreven, K. Throssell, J. A. Montgomery, Jr., J. E. Peralta, F. Ogliaro, M. J. Bearpark, J. J. Heyd, E. N. Brothers, K. N. Kudin, V. N. Staroverov, T. A. Keith, R. Kobayashi, J. Normand, K. Raghavachari, A. P. Rendell, J. C. Burant, S. S. Iyengar, J. Tomasi, M. Cossi, J. M. Millam, M. Klene, C. Adamo, R. Cammi, J. W. Ochterski, R. L. Martin, K. Morokuma, O. Farkas, J. B. Foresman, and D. J. Fox, Gaussian, Inc., Wallingford CT, 2016.]

Thus evaluated results correspond to approximation of «rigid rotor - harmonic oscillator». The most useful way to adjust the computed harmonic vibrational modes to the level of real molecules in gas phase is to scale them depending on the type of mode (stretching, deformational and so on). For complicated molecules distinguishing the type of vibrating mode is a challenging task and, in many cases, not possible. Therefore, we have divided the whole spectra into 4 regions: stretching $\mathrm{N}-\mathrm{H}$ vibration (near $3500 \mathrm{~cm}^{-1}$ ), stretching $\mathrm{C}-\mathrm{H}$ vibrations (2600 to $3100 \mathrm{~cm}^{-1}$ ) and deformation vibrations in the intervals 1000 to $2000 \mathrm{~cm}^{-1}$ and below $1000 \mathrm{~cm}^{-1}$. The values of scaling factors were evaluated by comparing the available in gas phase IR spectra [NIST_IR] for indole, indoline and 2-methyl indoline with computational results. For $8 \mathrm{H}$-indole only liquid phase IR spectrum is available for neat sample. No literature IR spectrum was found for 2-methyl-8H-indole. The results of comparison of scaled computed spectra with gas and liquid phase experimental spectrum is given in Figures S1-S4. In 2-methyl indoline and 2-methyl-8H-indole the methyl torsion was treated as a three-fold one-dimensional hindered rotor.

As it can be seen from Table 1 H8-indole, 2-methyl indoline and H8-2-methyl indole have a set of stereo enantiomers. For methyl substituent at position C2 we assumed the equal properties for both $R$ - and $S$ - enantiomers. Corresponding contribution was added for evaluation of the equimolar mixture of enantiomers $R \ln (0.5)$. In H8-indole form two stereo active atoms what leads to four possible enantiomers $(R-, S-),(S-, R-),(R-, R-)$, and $(S-, S-)$. Preliminary computations have shown that pairs $(R-, S-),(S-, R-)$ and $(S-, S-),(R-, R-)$ of optical isomers have equal properties. At the same time $(S-, R-)$ and $(R-, R-)$ have non-equal energy. Therefore, the thermodynamic properties were evaluated for $(R-, S-)$ and $(R-, R-)$ separately and summed assuming the equimolar composition of the final racemic mixture.

Computed molecular parameters are given in Table S14, where excellent agreement with the recent microwave measurements is seen for rotational constants. The thermodynamic properties in ideal gas state are listed in Tables S15-S20.

The evaluated thermodynamic properties agree within 1\% with the results of statistical thermodynamic calculations provided by Chirico. [Chirico report https://www.osti.gov/biblio/6124014] 
Table S14. Molecular properties of studied compounds. ${ }^{a}$

\begin{tabular}{|c|c|c|c|c|c|c|c|c|c|}
\hline & & & & & ole & & & & \\
\hline & & & & otation & nstants & & & & \\
\hline & & & $\mathrm{com}$ & $d^{b}$ & & & experim & & \\
\hline & A & & & & & & 3.87 & & \\
\hline & B & & & & & & 1.63 & & \\
\hline & $\mathrm{C}$ & & & & & & 1.15 & & \\
\hline & & & iputed ( & caled) $\mathrm{v}$ & ional $\mathrm{fl}$ & encies & $n^{-1}$ b,d & & \\
\hline 212 & 246 & 386 & 406 & 431 & 556 & 588 & 619 & 623 & 727 \\
\hline 752 & 782 & 783 & 859 & 866 & 893 & 918 & 940 & 979 & 1037 \\
\hline 1091 & 1110 & 1145 & 1177 & 1228 & 1274 & 1302 & 1367 & 1387 & 1444 \\
\hline 1484 & 1530 & 1552 & 1620 & 1662 & 3163 & 3169 & 3180 & 3192 & 3238 \\
\hline 3257 & 3678 & & & & & & & & \\
\hline
\end{tabular}

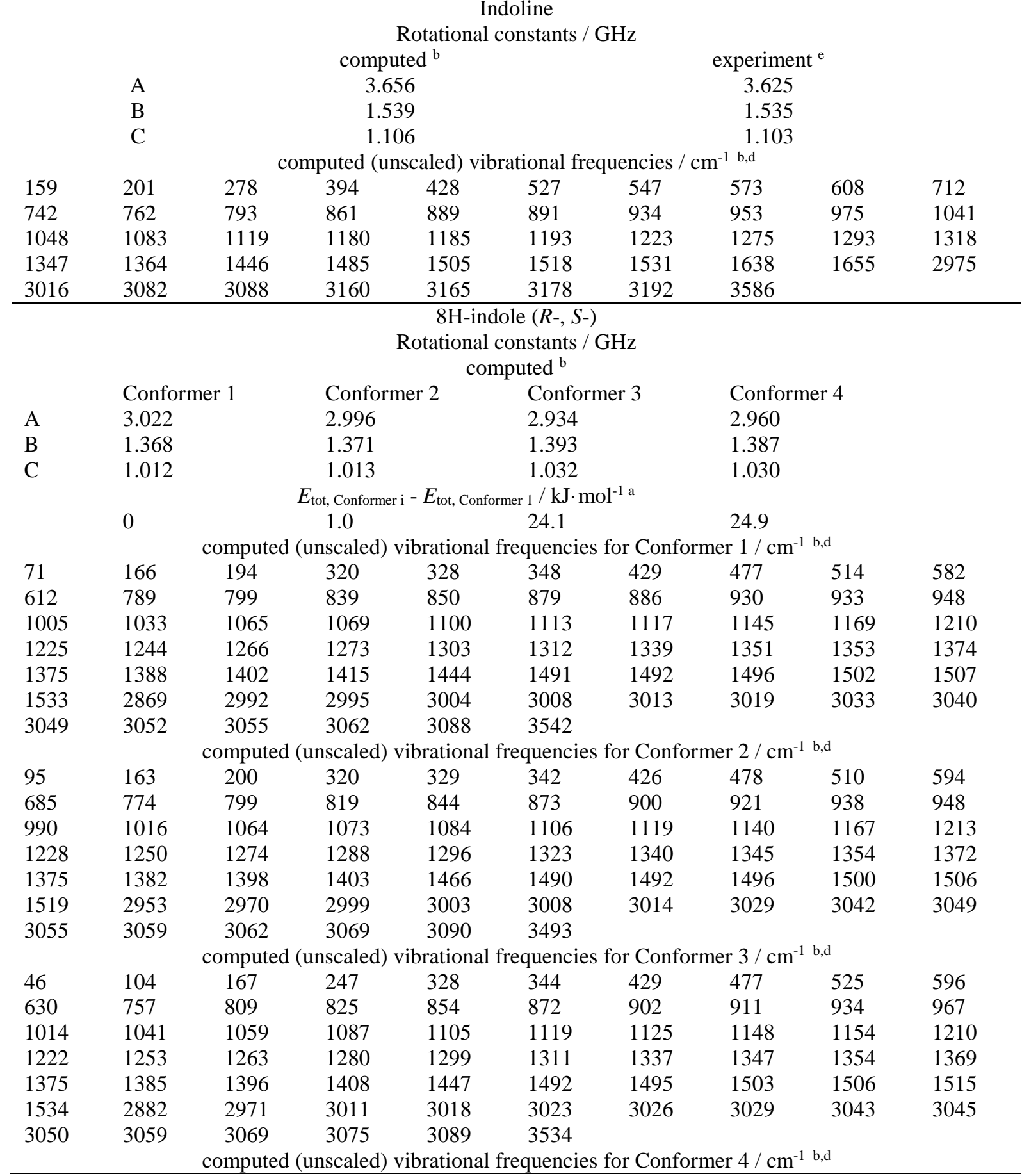




\begin{tabular}{llllllllll}
\hline 76 & 108 & 168 & 248 & 323 & 345 & 428 & 479 & 520 & 616 \\
682 & 755 & 791 & 821 & 852 & 854 & 902 & 914 & 933 & 966 \\
986 & 1027 & 1060 & 1090 & 1095 & 1110 & 1125 & 1133 & 1158 & 1209 \\
1227 & 1255 & 1276 & 1290 & 1295 & 1321 & 1340 & 1349 & 1353 & 1368 \\
1374 & 1383 & 1392 & 1394 & 1467 & 1491 & 1494 & 1500 & 1506 & 1514 \\
1519 & 2965 & 2988 & 3013 & 3018 & 3025 & 3029 & 3030 & 3043 & 3050 \\
3055 & 3069 & 3071 & 3075 & 3091 & 3491 & & & & \\
\hline
\end{tabular}

Rotational constants / GHz computed $^{\mathrm{b}}$

$\begin{array}{llllllllll} & \text { C1 } & \text { C2 } & \text { C3 } & \text { C4 } & \text { C5 } & \text { C6 } & \text { C7 } & \text { C8 } & \text { C9 } \\ \text { A } & 2.763 & 2.766 & 2.755 & 2.766 & 3.065 & 2.556 & 2.554 & 3.034 & 2.909 \\ \text { B } & 1.495 & 1.487 & 1.476 & 1.476 & 1.371 & 1.593 & 1.584 & 1.374 & 1.436 \\ \text { C } & 1.193 & 1.184 & 1.181 & 1.179 & 1.047 & 1.274 & 1.259 & 1.050 & 1.098 \\ & \text { C10 } & \text { C11 } & \text { C12 } & \text { C13 } & \text { C14 } & \text { C15 } & \text { C16 } & & \\ \text { A } & 2.536 & 2.546 & 2.327 & 2.325 & 2.472 & 2.475 & 2.762 & & \end{array}$

$\begin{array}{llllllll}\mathrm{B} & 1.591 & 1.581 & 1.710 & 1.714 & 1.604 & 1.597 & 1.484 \\ \mathrm{C} & 1.269 & 1.262 & 1.392 & 1.400 & 1.350 & 1.343 & 1.233\end{array}$

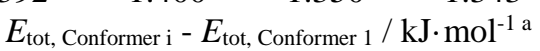

$\begin{array}{lllllllll}\text { C1 } & \text { C2 } & \text { C3 } & \text { C4 } & \text { C5 } & \text { C6 } & \text { C7 } & \text { C8 } & \text { C9 } \\ 0 & 2.1 & 4.3 & 4.5 & 12.2 & 12.4 & 13.1 & 13.9 & 16.9 \\ \text { C10 } & \text { C11 } & \text { C12 } & \text { C13 } & \text { C14 } & \text { C15 } & \text { C16 } & & \end{array}$

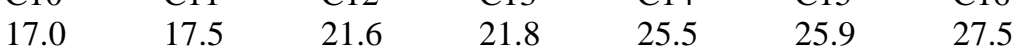

\begin{tabular}{|c|c|c|c|c|c|c|c|c|c|}
\hline \multicolumn{10}{|c|}{ computed (unscaled) vibrational frequencies for Conformer C1 / $\mathrm{cm}^{-1} \mathrm{b,d}$} \\
\hline 57 & 166 & 174 & 296 & 326 & 358 & 414 & 475 & 575 & 605 \\
\hline 704 & 766 & 788 & 816 & 860 & 861 & 894 & 915 & 931 & 947 \\
\hline 1009 & 1038 & 1043 & 1052 & 1064 & 1109 & 1112 & 1134 & 1168 & 1199 \\
\hline 1230 & 1240 & 1274 & 1275 & 1300 & 1317 & 1334 & 1356 & 1362 & 1376 \\
\hline 1381 & 1390 & 1404 & 1408 & 1445 & 1485 & 1488 & 1494 & 1501 & 1504 \\
\hline 1537 & 2901 & 2996 & 2997 & 3009 & 3020 & 3021 & 3026 & 3034 & 3041 \\
\hline 3047 & 3052 & 3060 & 3068 & 3084 & 3555 & & & & \\
\hline \multicolumn{10}{|c|}{ computed (unscaled) vibrational frequencies for Conformer C2 / $\mathrm{cm}^{-1} \mathrm{~b}, \mathrm{~d}$} \\
\hline 54 & 166 & 180 & 302 & 324 & 362 & 416 & 481 & 600 & 660 \\
\hline 710 & 768 & 783 & 801 & 825 & 858 & 903 & 912 & 917 & 957 \\
\hline 993 & 1013 & 1045 & 1056 & 1064 & 1094 & 1108 & 1134 & 1165 & 1197 \\
\hline 1229 & 1243 & 1276 & 1286 & 1297 & 1327 & 1341 & 1352 & 1355 & 1367 \\
\hline 1376 & 1383 & 1396 & 1406 & 1471 & 1484 & 1494 & 1497 & 1500 & 1508 \\
\hline 1523 & 2985 & 2999 & 3004 & 3010 & 3022 & 3027 & 3029 & 3046 & 3052 \\
\hline 3053 & 3056 & 3059 & 3062 & 3086 & 3535 & & & & \\
\hline \multicolumn{10}{|c|}{ computed (unscaled) vibrational frequencies for Conformer C3 / $\mathrm{cm}^{-1} \mathrm{~b}, \mathrm{~d}$} \\
\hline 95 & 161 & 185 & 298 & 349 & 370 & 415 & 483 & 588 & 620 \\
\hline 712 & 773 & 792 & 813 & 846 & 855 & 886 & 916 & 937 & 941 \\
\hline 987 & 1004 & 1052 & 1061 & 1068 & 1098 & 1112 & 1124 & 1149 & 1207 \\
\hline 1234 & 1245 & 1282 & 1282 & 1293 & 1316 & 1340 & 1346 & 1354 & 1372 \\
\hline 1374 & 1382 & 1393 & 1404 & 1466 & 1490 & 1494 & 1494 & 1503 & 1510 \\
\hline 1524 & 2997 & 2999 & 3012 & 3015 & 3022 & 3033 & 3037 & 3042 & 3052 \\
\hline 3054 & 3057 & 3068 & 3070 & 3092 & 3522 & & & & \\
\hline \multicolumn{10}{|c|}{ computed (unscaled) vibrational frequencies for Conformer $\mathrm{C} 4 / \mathrm{cm}^{-1} \mathrm{b,d}$} \\
\hline 78 & 164 & 184 & 298 & 349 & 360 & 411 & 476 & 584 & 612 \\
\hline 640 & 777 & 815 & 819 & 850 & 858 & 891 & 922 & 940 & 945 \\
\hline 992 & 1022 & 1050 & 1065 & 1083 & 1099 & 1113 & 1153 & 1162 & 1206 \\
\hline 1219 & 1253 & 1260 & 1282 & 1291 & 1302 & 1344 & 1353 & 1358 & 1371 \\
\hline 1380 & 1382 & 1395 & 1406 & 1447 & 1490 & 1493 & 1494 & 1504 & 1512 \\
\hline 1538 & 2977 & 3001 & 3006 & 3007 & 3013 & 3014 & 3036 & 3038 & 3044 \\
\hline 3047 & 3053 & 3055 & 3059 & 3092 & 3531 & & & & \\
\hline \multicolumn{10}{|c|}{ computed (unscaled) vibrational frequencies for Conformer C5 / $\mathrm{cm}^{-1} \mathrm{b,d}$} \\
\hline 53 & 175 & 191 & 274 & 323 & 378 & 436 & 485 & 560 & 587 \\
\hline 639 & 752 & 775 & 844 & 855 & 881 & 903 & 934 & 946 & 959 \\
\hline 1015 & 1041 & 1044 & 1068 & 1094 & 1113 & 1123 & 1144 & 1154 & 1215 \\
\hline 1224 & 1236 & 1264 & 1281 & 1297 & 1321 & 1330 & 1343 & 1352 & 1365 \\
\hline 1373 & 1384 & 1394 & 1404 & 1445 & 1491 & 1494 & 1497 & 1509 & 1518 \\
\hline 1523 & 2902 & 2918 & 3013 & 3019 & 3027 & 3030 & 3032 & 3045 & 3047 \\
\hline
\end{tabular}




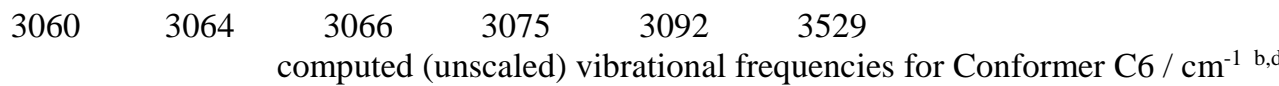

$\begin{array}{llllllllll}84 & 151 & 206 & 278 & 336 & 379 & 448 & 496 & 584 & 610 \\ 689 & 754 & 766 & 837 & 844 & 876 & 882 & 922 & 938 & 970 \\ 1011 & 1028 & 1039 & 1063 & 1086 & 1114 & 1120 & 1131 & 1173 & 1215 \\ 1222 & 1234 & 1259 & 1289 & 1294 & 1324 & 1330 & 1353 & 1356 & 1363 \\ 1384 & 1391 & 1396 & 1409 & 1443 & 1484 & 1492 & 1497 & 1506 & 1513 \\ 1524 & 2914 & 2919 & 3011 & 3019 & 3031 & 3038 & 3043 & 3047 & 3049 \\ 3052 & 3065 & 3065 & 3085 & 3094 & 3527 & & & & \end{array}$

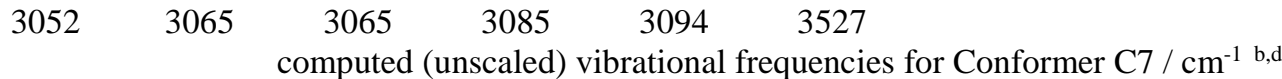

$\begin{array}{llllllllll}67 & 174 & 197 & 282 & 339 & 377 & 452 & 505 & 554 & 597 \\ 654 & 752 & 768 & 821 & 842 & 872 & 885 & 920 & 935 & 967 \\ 1006 & 1025 & 1054 & 1061 & 1086 & 1110 & 1120 & 1133 & 1170 & 1204 \\ 1221 & 1226 & 1261 & 1285 & 1297 & 1318 & 1338 & 1357 & 1361 & 1365 \\ 1377 & 1385 & 1399 & 1408 & 1446 & 1486 & 1494 & 1496 & 1505 & 1517 \\ 1526 & 2921 & 2953 & 3013 & 3019 & 3028 & 3035 & 3042 & 3043 & 3047 \\ 3055 & 3058 & 3060 & 3081 & 3094 & 3551 & & & \end{array}$

$30553058 \quad \begin{array}{cccc}3060 & 3081 & 3094 & 3551 \\ \text { computed (unscaled) vibrational frequencies for Conformer C8 / cm }\end{array}$

$\begin{array}{llllllllll}54 & 175 & 190 & 271 & 326 & 374 & 435 & 484 & 564 & 616 \\ 660 & 746 & 779 & 828 & 854 & 875 & 909 & 927 & 936 & 966 \\ 988 & 1025 & 1043 & 1066 & 1089 & 1105 & 1116 & 1127 & 1152 & 1213 \\ 1222 & 1247 & 1271 & 1286 & 1316 & 1324 & 1331 & 1341 & 1352 & 1364 \\ 1373 & 1379 & 1388 & 1396 & 1466 & 1491 & 1496 & 1496 & 1507 & 1509 \\ 1517 & 2989 & 3003 & 3012 & 3017 & 3019 & 3026 & 3029 & 3030 & 3046\end{array}$

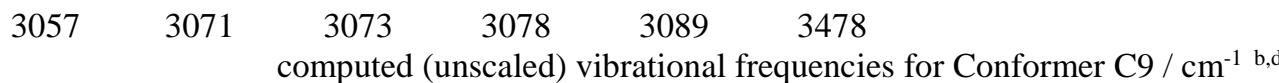

$\begin{array}{llllllllll}20 & 161 & 180 & 281 & 334 & 404 & 436 & 449 & 579 & 590 \\ 702 & 753 & 773 & 787 & 849 & 877 & 907 & 937 & 948 & 961 \\ 1019 & 1033 & 1038 & 1057 & 1084 & 1108 & 1127 & 1144 & 1156 & 1205 \\ 1220 & 1241 & 1261 & 1275 & 1283 & 1320 & 1342 & 1346 & 1353 & 1367 \\ 1373 & 1386 & 1390 & 1392 & 1450 & 1489 & 1493 & 1495 & 1510 & 1518 \\ 1529 & 2926 & 2995 & 3011 & 3018 & 3023 & 3032 & 3037 & 3046 & 3049\end{array}$

$3053 \quad 3059 \quad \begin{array}{llcc}3064 & 3075 & 3090 & 3529 \\ \text { computed (unscaled) vibrational frequencies for Conformer } \mathrm{C} 10 / \mathrm{cm}^{-1} \mathrm{~b}, \mathrm{~d}\end{array}$

\begin{tabular}{|c|c|c|c|c|c|c|c|c|c|}
\hline 91 & 154 & 203 & 274 & 343 & 378 & 449 & 495 & 592 & 628 \\
\hline 709 & 747 & 765 & 817 & 839 & 856 & 890 & 903 & 935 & 969 \\
\hline 984 & 1019 & 1040 & 1060 & 1078 & 1094 & 1106 & 1134 & 1176 & 1214 \\
\hline 1223 & 1233 & 1264 & 1292 & 1319 & 1320 & 1333 & 1349 & 1358 & 1361 \\
\hline 1377 & 1381 & 1394 & 1397 & 1470 & 1489 & 1494 & 1502 & 1505 & 1510 \\
\hline 1520 & 3005 & 3013 & 3015 & 3021 & 3030 & 3033 & 3035 & 3044 & 304 \\
\hline 3051 & 3066 & 3075 & 3078 & 3088 & 3501 & & & & \\
\hline \multicolumn{10}{|c|}{ computed (unscaled) vibrational frequencies for Conformer C11 / $\mathrm{cm}^{-1} \mathrm{~b}, \mathrm{~d}$} \\
\hline 78 & 166 & 197 & 275 & 333 & 382 & 448 & 493 & 596 & 606 \\
\hline 706 & 733 & 763 & 778 & 841 & 861 & 891 & 921 & 937 & 962 \\
\hline 972 & 1022 & 1045 & 1067 & 1080 & 1088 & 1121 & 1141 & 1166 & 1206 \\
\hline 1226 & 1237 & 1271 & 1290 & 1311 & 1326 & 1336 & 1355 & 1360 & 136 \\
\hline 1378 & 1380 & 1396 & 1404 & 1470 & 1491 & 1496 & 1497 & 1507 & 15 \\
\hline 1518 & 3003 & 3004 & 3015 & 3019 & 3025 & 3031 & 3036 & 3037 & 30 \\
\hline 3056 & 3059 & 3073 & 3077 & 3084 & 3520 & & & & \\
\hline \multicolumn{10}{|c|}{ computed (unscaled) vibrational frequencies for Conformer C12 / $\mathrm{cm}^{-1} \mathrm{~b}, \mathrm{~d}$} \\
\hline 80 & 165 & 202 & 234 & 391 & 397 & 435 & 512 & 577 & 634 \\
\hline 719 & 743 & 774 & 808 & 824 & 843 & 870 & 918 & 923 & 958 \\
\hline 1002 & 1013 & 1032 & 1057 & 1070 & 1104 & 1118 & 1134 & 1165 & 11 \\
\hline 1217 & 1226 & 1258 & 1283 & 1295 & 1328 & 1337 & 1354 & 1355 & 136 \\
\hline 1368 & 1377 & 1400 & 1402 & 1463 & 1485 & 1495 & 1499 & 1507 & 15 \\
\hline 1528 & 3011 & 3022 & 3026 & 3029 & 3031 & 3034 & 3042 & 3050 & 30 \\
\hline 3057 & 3069 & 3071 & 3080 & 3085 & 3538 & & & & \\
\hline \multicolumn{10}{|c|}{ computed (unscaled) vibrational frequencies for Conformer $\mathrm{C} 13 / \mathrm{cm}^{-1} \mathrm{~b}, \mathrm{~d}$} \\
\hline 84 & 168 & 207 & 249 & 384 & 391 & 426 & 498 & 556 & 607 \\
\hline 724 & 742 & 776 & 784 & 843 & 851 & 892 & 929 & 935 & 958 \\
\hline 1003 & 1026 & 1040 & 1071 & 1082 & 1101 & 1118 & 1156 & 1171 & 119 \\
\hline 1219 & 1231 & 1254 & 1282 & 1287 & 1322 & 1341 & 1352 & 1359 & 13 \\
\hline
\end{tabular}




\begin{tabular}{|c|c|c|c|c|c|c|c|c|c|}
\hline 1373 & 1386 & 1400 & 1404 & 1453 & 1489 & 1493 & 1499 & 1508 & 1517 \\
\hline 1541 & 2949 & 2998 & 3014 & 3020 & 3028 & 3037 & 3039 & 3043 & 3049 \\
\hline 3052 & 3055 & 3062 & 3077 & 3089 & 3544 & & & & \\
\hline \multicolumn{10}{|c|}{ computed (unscaled) vibrational frequencies for Conformer C14 / $\mathrm{cm}^{-1} \mathrm{~b}, \mathrm{~d}$} \\
\hline 61 & 155 & 184 & 227 & 319 & 395 & 437 & 465 & 605 & 614 \\
\hline 699 & 764 & 781 & 798 & 843 & 846 & 882 & 905 & 935 & 951 \\
\hline 1004 & 1036 & 1042 & 1073 & 1088 & 1098 & 1122 & 1149 & 1178 & 1203 \\
\hline 1219 & 1238 & 1263 & 1287 & 1293 & 1299 & 1332 & 1346 & 1361 & 1369 \\
\hline 1376 & 1383 & 1398 & 1402 & 1453 & 1488 & 1494 & 1505 & 1506 & 1518 \\
\hline 1544 & 2957 & 2998 & 3015 & 3018 & 3029 & 3035 & 3036 & 3044 & 3048 \\
\hline 3053 & 3059 & 3064 & 3080 & 3096 & 3538 & & & & \\
\hline \multicolumn{10}{|c|}{ computed (unscaled) vibrational frequencies for Conformer C15 / $\mathrm{cm}^{-1} \mathrm{b,d}$} \\
\hline 55 & 153 & 184 & 225 & 320 & 406 & 442 & 479 & 611 & 680 \\
\hline 698 & 757 & 771 & 805 & 826 & 843 & 859 & 901 & 927 & 953 \\
\hline 1007 & 1008 & 1039 & 1066 & 1075 & 1086 & 1124 & 1137 & 1170 & 1203 \\
\hline 1216 & 1256 & 1265 & 1283 & 1293 & 1319 & 1333 & 1344 & 1357 & 1368 \\
\hline 1374 & 1378 & 1394 & 1403 & 1470 & 1485 & 1494 & 1504 & 1506 & 1515 \\
\hline 1529 & 3008 & 3017 & 3028 & 3030 & 3033 & 3044 & 3045 & 3048 & 3056 \\
\hline 3060 & 3071 & 3075 & 3081 & 3093 & 3524 & & & & \\
\hline \multicolumn{10}{|c|}{ computed (unscaled) vibrational frequencies for Conformer C16 / $\mathrm{cm}^{-1} \mathrm{b,d}$} \\
\hline 43 & 99 & 168 & 267 & 324 & 348 & 406 & 473 & 593 & 628 \\
\hline 709 & 749 & 764 & 835 & 862 & 866 & 902 & 909 & 924 & 947 \\
\hline 1000 & 1034 & 1045 & 1058 & 1071 & 1114 & 1125 & 1142 & 1186 & 1198 \\
\hline 1222 & 1231 & 1273 & 1274 & 1308 & 1315 & 1331 & 1353 & 1360 & 1370 \\
\hline 1381 & 1390 & 1397 & 1401 & 1442 & 1486 & 1492 & 1499 & 1504 & 1509 \\
\hline 1536 & 2910 & 2998 & 3004 & 3020 & 3022 & 3026 & 3032 & 3041 & 3049 \\
\hline 3054 & 3063 & 3064 & 3078 & 3087 & 3548 & & & & \\
\hline \multicolumn{10}{|c|}{$\begin{array}{c}\text { 2-methyl indoline } \\
\text { Rotational constants }(R-) \text { / GHz } \\
\text { computed }^{\mathrm{b}}\end{array}$} \\
\hline & \multicolumn{5}{|c|}{ Conformer 1} & \multicolumn{4}{|c|}{ Conformer2 } \\
\hline A & \multicolumn{5}{|l|}{3.536} & \multicolumn{4}{|l|}{2.951} \\
\hline B & \multicolumn{5}{|l|}{0.9688} & \multicolumn{4}{|l|}{1.070} \\
\hline \multirow[t]{5}{*}{ C } & \multicolumn{5}{|l|}{0.7795} & \multicolumn{4}{|l|}{0.8853} \\
\hline & \multirow{2}{*}{\multicolumn{9}{|c|}{$E_{\text {tot, Conformer i }-} E_{\text {tot, Conformer } 1 / \mathrm{kJ} \cdot \mathrm{mol}^{-1 \mathrm{a}}}$}} \\
\hline & & & & & & & & & \\
\hline & & & Metl & torsion $\mathrm{b}$ & rier: 6.78 & $\mathrm{~J} \mathrm{~mol}^{-1}$ & & & \\
\hline & \multicolumn{9}{|c|}{ computed (unscaled) vibrational frequencies for Conformer $1 / \mathrm{cm}^{-1} \mathrm{b,d}$} \\
\hline 88 & 192 & $236^{\mathrm{f}}$ & 259 & 267 & 424 & 431 & 440 & 509 & 545 \\
\hline 598 & 614 & 693 & 738 & 764 & 812 & 857 & 864 & 896 & 925 \\
\hline 947 & 955 & 975 & 1047 & 1064 & 1112 & 1127 & 1154 & 1181 & 1193 \\
\hline 1205 & 1271 & 1280 & 1303 & 1345 & 1358 & 1392 & 1416 & 1441 & 1485 \\
\hline 1494 & 1500 & 1506 & 1524 & 1639 & 1656 & 2948 & 3003 & 3027 & 3085 \\
\hline 3087 & 3100 & 3160 & 3165 & 3177 & 3192 & 3579 & & & \\
\hline \multicolumn{10}{|c|}{ computed (unscaled) vibrational frequencies for Conformer $2 / \mathrm{cm}^{-1} \mathrm{b,d}$} \\
\hline 86 & 167 & $254^{\mathrm{f}}$ & 261 & 334 & 400 & 425 & 431 & 534 & 552 \\
\hline 593 & 630 & 729 & 737 & 763 & 825 & 830 & 861 & 892 & 923 \\
\hline 943 & 957 & 974 & 1044 & 1048 & 1096 & 1120 & 1136 & 1181 & 1190 \\
\hline 1208 & 1255 & 1276 & 1318 & 1332 & 1360 & 1382 & 1408 & 1437 & 1485 \\
\hline 1496 & 1498 & 1506 & 1524 & 1638 & 1654 & 3020 & 3022 & 3052 & 3074 \\
\hline 3084 & 3094 & 3159 & 3165 & 3177 & 3192 & 3575 & & & \\
\hline & & & & $\begin{array}{l}\text { hethyl-81 } \\
\text { tational } \\
\text { con }\end{array}$ & $\begin{array}{l}\text { ndole }(R \\
\text { nstants / } \\
\text { uted }^{\mathrm{b}}\end{array}$ & & & & \\
\hline & C1 & $\mathrm{C} 2$ & C3 & C4 & C5 & C6 & C7 & C8 & C9 \\
\hline A & 2.354 & 2.316 & 2.418 & 2.212 & 2.898 & 2.244 & 2.862 & 2.892 & 2.193 \\
\hline B & 1.008 & 1.017 & 0.9815 & 1.056 & 0.8962 & 1.043 & 0.8998 & 0.8947 & 1.058 \\
\hline C & 0.8994 & 0.9122 & 0.8696 & 0.9486 & 0.7531 & 0.9323 & 0.7564 & 0.7466 & 0.9497 \\
\hline & C10 & C11 & C12 & & & & & & \\
\hline
\end{tabular}




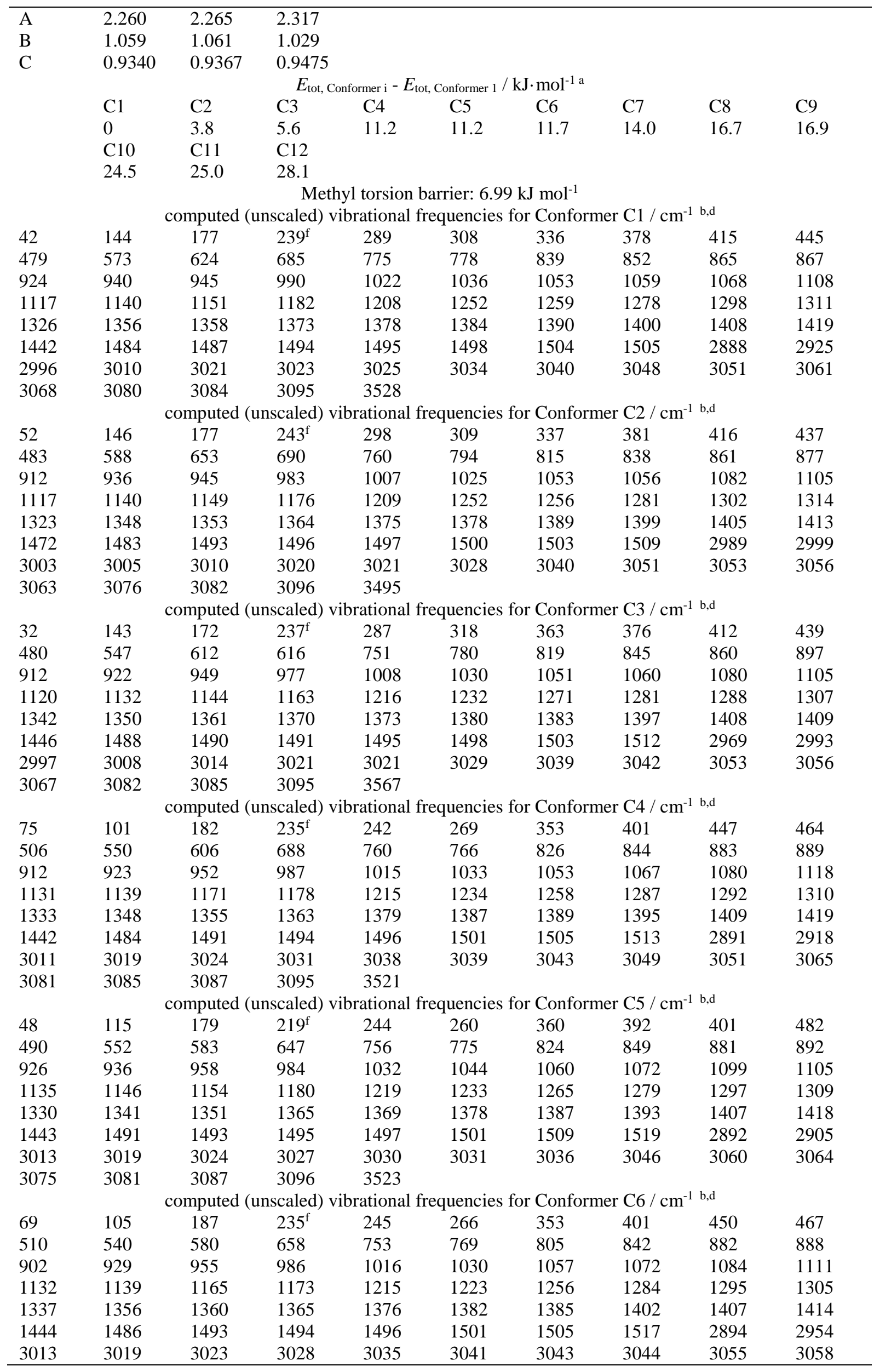




\begin{tabular}{|c|c|c|c|c|c|c|c|c|c|}
\hline \multirow[t]{2}{*}{3081} & 3081 & 3087 & 3096 & 3545 & & & & & \\
\hline & & \multicolumn{8}{|c|}{ computed (unscaled) vibrational frequencies for Conformer $\mathrm{C} 7 / \mathrm{cm}^{-1} \mathrm{b,d}$} \\
\hline 48 & 112 & 180 & $225^{f}$ & 246 & 262 & 363 & 391 & 402 & 473 \\
\hline 483 & 560 & 594 & 671 & 749 & 779 & 819 & 854 & 870 & 900 \\
\hline 922 & 934 & 956 & 969 & 1021 & 1042 & 1070 & 1074 & 1095 & 1114 \\
\hline 1130 & 1137 & 1153 & 1173 & 1217 & 1244 & 1269 & 1282 & 1298 & 1306 \\
\hline 1325 & 1339 & 1351 & 1365 & 1372 & 1373 & 1379 & 1392 & 1403 & 1415 \\
\hline 1466 & 1491 & 1492 & 1496 & 1499 & 1501 & 1509 & 1517 & 2987 & 2990 \\
\hline 3004 & 3011 & 3015 & 3019 & 3021 & 3028 & 3029 & 3046 & 3057 & 3070 \\
\hline \multirow[t]{2}{*}{3072} & 3074 & 3082 & 3101 & 3460 & & & & & \\
\hline & & \multicolumn{8}{|c|}{ computed (unscaled) vibrational frequencies for Conformer $\mathrm{C} 8 / \mathrm{cm}^{-1} \mathrm{~b}, \mathrm{~d}$} \\
\hline 75 & 101 & 185 & $238^{\mathrm{f}}$ & 245 & 274 & 355 & 405 & 446 & 457 \\
\hline 499 & 558 & 610 & 715 & 750 & 768 & 815 & 838 & 872 & 892 \\
\hline 900 & 923 & 940 & 977 & 1012 & 1031 & 1047 & 1072 & 1083 & 1110 \\
\hline 1131 & 1138 & 1170 & 1177 & 1219 & 1232 & 1264 & 1289 & 1295 & 1307 \\
\hline 1326 & 1340 & 1359 & 1361 & 1370 & 1376 & 1390 & 1395 & 1403 & 1415 \\
\hline 1469 & 1488 & 1492 & 1496 & 1500 & 1503 & 1507 & 1519 & 2987 & 3005 \\
\hline 3013 & 3017 & 3021 & 3025 & 3030 & 3035 & 3043 & 3048 & 3051 & 3065 \\
\hline 3073 & 3075 & 3082 & 3100 & 3482 & & & & & \\
\hline \multicolumn{10}{|c|}{ computed (unscaled) vibrational frequencies for Conformer C9 / $\mathrm{cm}^{-1} \mathrm{b,d}$} \\
\hline 76 & 99 & 188 & $239^{\mathrm{f}}$ & 248 & 271 & 352 & 402 & 447 & 456 \\
\hline 501 & 555 & 605 & 703 & 730 & 767 & 786 & 843 & 877 & 885 \\
\hline 905 & 932 & 943 & 973 & 1009 & 1030 & 1056 & 1075 & 1079 & 1113 \\
\hline 1136 & 1149 & 1167 & 1181 & 1213 & 1234 & 1264 & 1280 & 1292 & 1319 \\
\hline 1329 & 1354 & 1359 & 1362 & 1368 & 1380 & 1388 & 1399 & 1404 & 1413 \\
\hline 1473 & 1491 & 1493 & 1497 & 1499 & 1501 & 1508 & 1518 & 2977 & 3002 \\
\hline 3015 & 3017 & 3020 & 3024 & 3026 & 3034 & 3037 & 3045 & 3056 & 3059 \\
\hline 3071 & 3075 & 3081 & 3099 & 3500 & & & & & \\
\hline \multicolumn{10}{|c|}{ computed (unscaled) vibrational frequencies for Conformer $\mathrm{C} 10 / \mathrm{cm}^{-1} \mathrm{~b}, \mathrm{~d}$} \\
\hline 47 & 116 & 152 & $230^{\mathrm{f}}$ & 233 & 334 & 357 & 373 & 417 & 441 \\
\hline 457 & 575 & 678 & 730 & 742 & 773 & 806 & 810 & 836 & 854 \\
\hline 907 & 936 & 957 & 970 & 1014 & 1038 & 1049 & 1082 & 1085 & 1090 \\
\hline 1117 & 1130 & 1142 & 1157 & 1224 & 1237 & 1250 & 1271 & 1291 & 1300 \\
\hline 1334 & 1340 & 1351 & 1354 & 1370 & 1373 & 1375 & 1392 & 1406 & 1412 \\
\hline 1463 & 1489 & 1490 & 1496 & 1501 & 1501 & 1510 & 1520 & 3007 & 3013 \\
\hline 3024 & 3027 & 3031 & 3032 & 3034 & 3041 & 3046 & 3049 & 3063 & 3071 \\
\hline 3073 & 3080 & 3095 & 3110 & 3548 & & & & & \\
\hline \multicolumn{10}{|c|}{ computed (unscaled) vibrational frequencies for Conformer $\mathrm{C} 11 / \mathrm{cm}^{-1} \mathrm{b,d}$} \\
\hline 45 & 120 & 153 & $235^{f}$ & 242 & 325 & 350 & 375 & 396 & 437 \\
\hline 441 & 575 & 643 & 733 & 742 & 764 & 784 & 805 & 850 & 882 \\
\hline 922 & 930 & 961 & 978 & 1017 & 1043 & 1046 & 1078 & 1087 & 1089 \\
\hline 1121 & 1143 & 1158 & 1170 & 1226 & 1239 & 1254 & 1273 & 1291 & 1293 \\
\hline 1340 & 1346 & 1353 & 1363 & 1373 & 1381 & 1390 & 1392 & 1397 & 1406 \\
\hline 1454 & 1490 & 1493 & 1495 & 1497 & 1502 & 1511 & 1520 & 2977 & 3003 \\
\hline 3018 & 3021 & 3023 & 3029 & 3032 & 3037 & 3047 & 3052 & 3059 & 3064 \\
\hline 3074 & 3078 & 3087 & 3104 & 3537 & & & & & \\
\hline \multicolumn{10}{|c|}{ computed (unscaled) vibrational frequencies for Conformer $\mathrm{C} 12 / \mathrm{cm}^{-1} \mathrm{~b}, \mathrm{~d}$} \\
\hline 39 & 71 & 151 & $242^{\mathrm{f}}$ & 268 & 287 & 346 & 376 & 401 & 441 \\
\hline 476 & 586 & 637 & 697 & 753 & 774 & 826 & 861 & 866 & 872 \\
\hline 919 & 933 & 953 & 983 & 1020 & 1036 & 1047 & 1066 & 1075 & 1118 \\
\hline 1126 & 1146 & 1154 & 1191 & 1205 & 1241 & 1253 & 1273 & 1303 & 1309 \\
\hline 1329 & 1351 & 1360 & 1368 & 1375 & 1380 & 1391 & 1397 & 1405 & 1414 \\
\hline 1440 & 1486 & 1492 & 1493 & 1497 & 1501 & 1506 & 1511 & 2898 & 2941 \\
\hline 3004 & 3020 & 3023 & 3024 & 3031 & 3043 & 3054 & 3058 & 3061 & 3063 \\
\hline 3076 & 3081 & 3086 & 3096 & 3531 & & & & & \\
\hline
\end{tabular}




\begin{tabular}{|c|c|c|c|c|c|c|c|c|c|}
\hline \multicolumn{10}{|c|}{$\begin{array}{c}\text { 2-methyl-8H-indole ( } R-,, S-) \\
\text { Rotational constants / GHz } \\
\text { computed }^{\text {b }}\end{array}$} \\
\hline & \multicolumn{2}{|c|}{ Conformer 1} & \multicolumn{2}{|c|}{ Conformer 2} & \multicolumn{2}{|c|}{ Conformer 3} & \multicolumn{3}{|c|}{ Conformer 4} \\
\hline A & \multicolumn{2}{|l|}{2.805} & \multicolumn{2}{|c|}{2.751} & \multicolumn{2}{|l|}{2.789} & \multicolumn{3}{|c|}{2.704} \\
\hline B & \multicolumn{2}{|l|}{0.9065} & \multicolumn{2}{|l|}{0.9137} & \multicolumn{2}{|c|}{0.9101} & \multicolumn{3}{|c|}{0.9246} \\
\hline $\mathrm{C}$ & \multicolumn{2}{|l|}{0.7459} & 0.7529 & & \multicolumn{2}{|c|}{0.7509} & \multicolumn{3}{|c|}{0.7637} \\
\hline \multicolumn{10}{|c|}{$E_{\text {tot, Conformer i }}-E_{\text {tot, Conformer 1 }} / \mathrm{kJ} \cdot \mathrm{mol}^{-1} \mathrm{a}$} \\
\hline & \multicolumn{2}{|c|}{ Conformer 1} & \multicolumn{2}{|c|}{ Conformer 2} & \multicolumn{2}{|c|}{ Conformer 3} & \multicolumn{3}{|c|}{ Conformer 4} \\
\hline & 0.0 & & 1.3 & & 24.0 & & 25.4 & & \\
\hline & & rompute & nscaled) & rationa & equencie & r Conf & $1 / \mathrm{cm}$ & & \\
\hline 47 & 152 & 192 & $243^{f}$ & 278 & 322 & 346 & 387 & 393 & 457 \\
\hline 477 & 517 & 587 & 595 & 763 & 792 & 840 & 853 & 864 & 889 \\
\hline 924 & 934 & 946 & 959 & 1026 & 1047 & 1065 & 1070 & 1110 & 1114 \\
\hline 1117 & 1129 & 1170 & 1185 & 1212 & 1229 & 1265 & 1273 & 1295 & 1318 \\
\hline 1340 & 1349 & 1353 & 1366 & 1374 & 1375 & 1389 & 1403 & 1409 & 1414 \\
\hline 1451 & 1490 & 1491 & 1494 & 1496 & 1499 & 1503 & 1507 & 2880 & 2991 \\
\hline 2992 & 3004 & 3006 & 3012 & 3014 & 3019 & 3021 & 3049 & 3053 & 3055 \\
\hline 3062 & 3076 & 3078 & 3084 & 3537 & & & & & \\
\hline & & compute & nscaled) & rationa & equencie & r Conf & $2 / \mathrm{cn}$ & & \\
\hline 49 & 148 & 193 & $243^{f}$ & 274 & 321 & 339 & 386 & 404 & 458 \\
\hline 478 & 521 & 591 & 648 & 763 & 806 & 826 & 849 & 872 & 876 \\
\hline 924 & 930 & 943 & 965 & 1019 & 1043 & 1064 & 1076 & 1107 & 1111 \\
\hline 1121 & 1124 & 1156 & 1170 & 1218 & 1233 & 1267 & 1278 & 1294 & 1325 \\
\hline 1328 & 1343 & 1346 & 1372 & 1373 & 1378 & 1384 & 1397 & 1401 & 1410 \\
\hline 1463 & 1490 & 1490 & 1492 & 1496 & 1497 & 1502 & 1506 & 2954 & 2970 \\
\hline 2998 & 3003 & 3008 & 3014 & 3020 & 3023 & 3026 & 3049 & 3055 & 3058 \\
\hline 3061 & 3079 & 3084 & 3099 & 3506 & & & & & \\
\hline & & compute & nscaled) & rationa & equencie & r Conf & $\mathrm{r} 3 / \mathrm{cn}$ & & \\
\hline 38 & 103 & 147 & $243^{f}$ & 246 & 280 & 327 & 384 & 405 & 460 \\
\hline 479 & 516 & 587 & 604 & 741 & 769 & 843 & 854 & 871 & 886 \\
\hline 910 & 934 & 945 & 979 & 1023 & 1054 & 1062 & 1087 & 1112 & 1114 \\
\hline 1128 & 1134 & 1163 & 1182 & 1216 & 1219 & 1272 & 1278 & 1289 & 1320 \\
\hline 1340 & 1349 & 1353 & 1365 & 1370 & 1375 & 1386 & 1401 & 1403 & 1410 \\
\hline 1455 & 1492 & 1494 & 1496 & 1499 & 1503 & 1506 & 1515 & 2906 & 2983 \\
\hline 3000 & 3013 & 3015 & 3020 & 3021 & 3026 & 3028 & 3049 & 3060 & 3068 \\
\hline 3075 & 3076 & 3080 & 3083 & 3543 & & & & & \\
\hline & & compute & nscaled) & rationa & equencie & or Conf & $4 / \mathrm{cn}$ & & \\
\hline 36 & 101 & 141 & $244^{\mathrm{f}}$ & 246 & 281 & 321 & 384 & 410 & 466 \\
\hline 479 & 524 & 608 & 644 & 742 & 800 & 825 & 852 & 861 & 875 \\
\hline 910 & 935 & 941 & 984 & 1018 & 1047 & 1063 & 1096 & 1109 & 1116 \\
\hline 1125 & 1128 & 1147 & 1163 & 1216 & 1228 & 1277 & 1279 & 1290 & 1315 \\
\hline 1337 & 1343 & 1350 & 1365 & 1373 & 1377 & 1384 & 1390 & 1398 & 1409 \\
\hline 1464 & 1490 & 1491 & 1494 & 1496 & 1502 & 1506 & 1514 & 2964 & 2986 \\
\hline 3012 & 3017 & 3019 & 3021 & 3024 & 3026 & 3030 & 3050 & 3054 & 3070 \\
\hline 3075 & 3079 & 3084 & 3098 & 3513 & & & & & \\
\hline $\begin{array}{l}\text { a all con } \\
\text { b compu } \\
\text { c experil } \\
363 \text { (2019) }\end{array}$ & $\begin{array}{l}\text { prope } \\
\text { this wc } \\
\text { l data fr } \\
\text { [R.D. Suen }\end{array}$ & $\begin{array}{l}\text { were ca } \\
\text { referenc } \\
\text { J. Lovas, C }\end{array}$ & $\begin{array}{l}\text { ted at B? } \\
\text { Vavra, K. L } \\
\text { ser, J. Mol. S }\end{array}$ & sc. 127 (19 & $2-480].[$ W. C & $\begin{array}{l}\text { theory. } \\
\text { tional spect } \\
\text { ati, S. Di Be }\end{array}$ & J. Mol. Stru & 253 (1990) & $\begin{array}{l}\text { Mol. Spectrosc. } \\
\text { S. Gruet, O. Pirali, }\end{array}$ \\
\hline M. Goubet, & Tokaryk, P. B & ignac, J. Phys & 1. A. 120 & -105.][R. N & a, T. Studech & Uhlíková, & n, J. Mol. S & c. 339 (201 & \\
\hline $\begin{array}{l}\text { d Scaling } \\
\text { for indo } \\
2000 \mathrm{~cm} \\
\text { for indo } \\
\text { frequen } \\
\text { for } 8 \mathrm{H}-\mathrm{i} \\
\text { for } 2-\mathrm{me} \\
(<1000 \\
\text { e experi } \\
\text { calculations. }\end{array}$ & $\begin{array}{l}\text { ors used } \\
56 \text { for } 1 \\
\text { id } 0.985 \\
\text { nd 2-me } \\
\text { erval } 10 \\
0.956 \text { ( } \\
\text { indoline } \\
\text { ldata fr } \\
\text { lar Physics }\end{array}$ & $\begin{array}{l}\text { entropy } \\
\text { hydroge } \\
\text { frequen } \\
\text { l 8H-ind } \\
\text { to } 2000 \\
\text { H), } 0.955 \\
26 \text { (N-H } \\
\text { [W. Camina } \\
\text { 5, 1993, } 1561\end{array}$ & $\begin{array}{l}\text { lations } \\
\text { etch, } 0.9 \\
\text { below } 10 \\
0.956 \text { for } \\
\text { and } 0.93 \\
\text { H), } 0.965 \\
00-2.2 \text {. } \\
\text { Favero, B. }\end{array}$ & $\begin{array}{l}\text { or C-H } \\
\mathrm{m}^{-1} \text {; } \\
1 \text { hydro } \\
10^{-5} v_{\text {calc }} \\
\cdot 10^{-6} v_{\text {ca }} \\
v_{\text {calc }}(\mathrm{C}-1 \\
\text {, F. Zerbett }\end{array}$ & $\begin{array}{l}\text { ogen stre } \\
\text { stretch, } 0 \\
\text { frequenc } \\
00 \text { to } 20 \\
829+5 \\
\text { udy of the lar }\end{array}$ & $\begin{array}{l}\text { s, } 0.97 \\
\text { for C-1 } \\
\text { below } 1 \\
\left.m^{-1}\right) \text {, an } \\
{ }^{2} v_{\text {calc }}(10\end{array}$ & $\begin{array}{l}0^{-6} V_{\text {calc }} \mathrm{f} \\
\text { Irogen } \mathrm{s} \\
\mathrm{m}^{-1} ; \\
85(<10 \\
2000 \mathrm{c} \\
\text { ndoline thrc }\end{array}$ & $\begin{array}{l}\text { equency } \\
\text { les, } 0.9 \\
\mathrm{~m}^{-1} \text { ), co } \\
\text { and } 0.7 \\
\text { icrowave sp }\end{array}$ & $\begin{array}{l}\text { rval } 1000 \text { to } \\
\cdot 10^{-6} v_{\text {calc for }} \\
\text { ondingly; } \\
1.5 \cdot 10^{-4} v_{\text {calc }} \\
\text { copy and ab initio }\end{array}$ \\
\hline
\end{tabular}




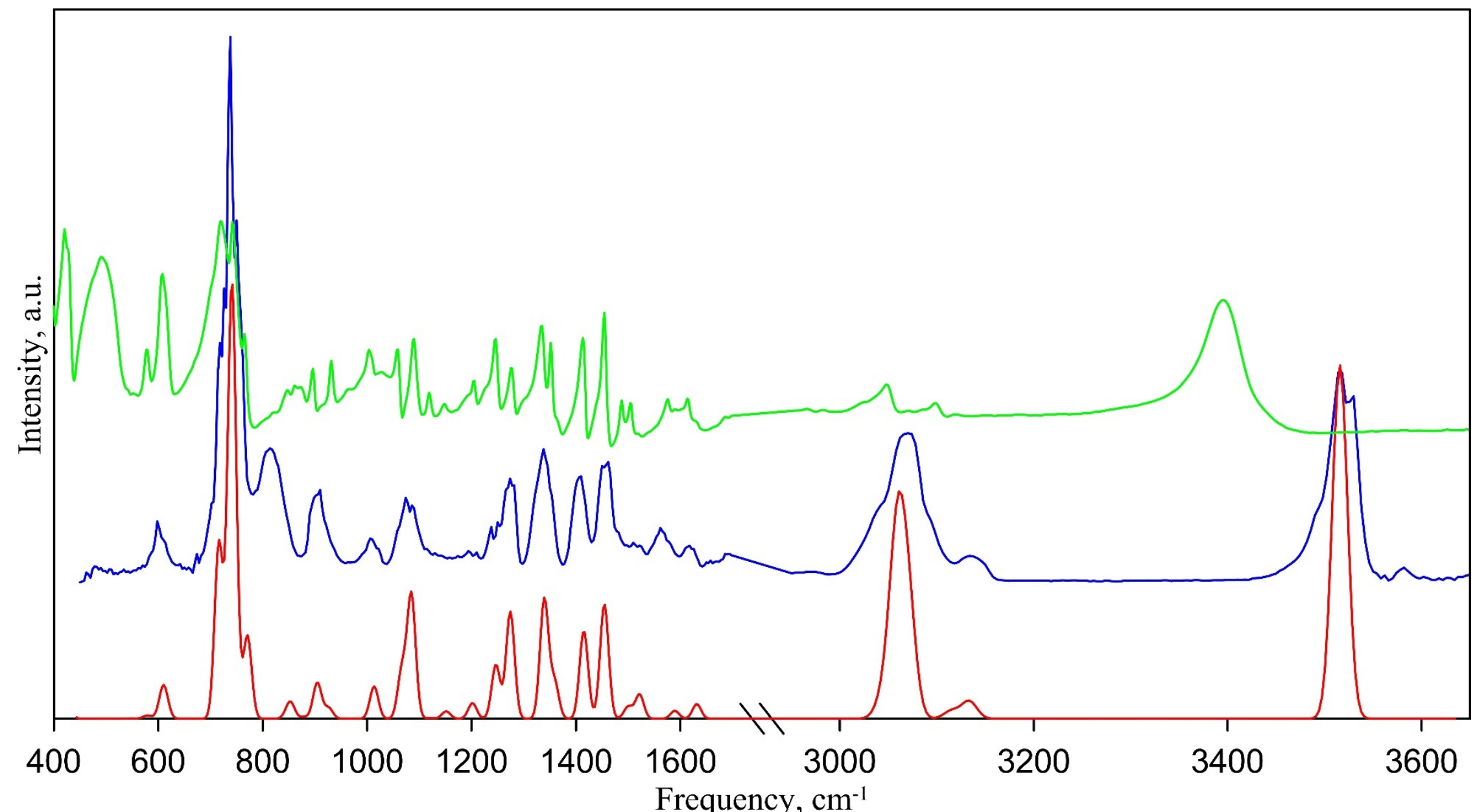

Figure S1. The comparison of IR indole spectra evaluated at B3LYP/cc-VPZT (D3BJ) (Gaussian broadening $25 \mathrm{~cm}^{-1}$ at half height) red line with experimental gas phase IR spectrum [NIST Standard Reference Data Program. Sadtler Research Labs. Via Webbook.nist.gov ] (blue line) and liquid phase ATR-FTIR study(green line). 


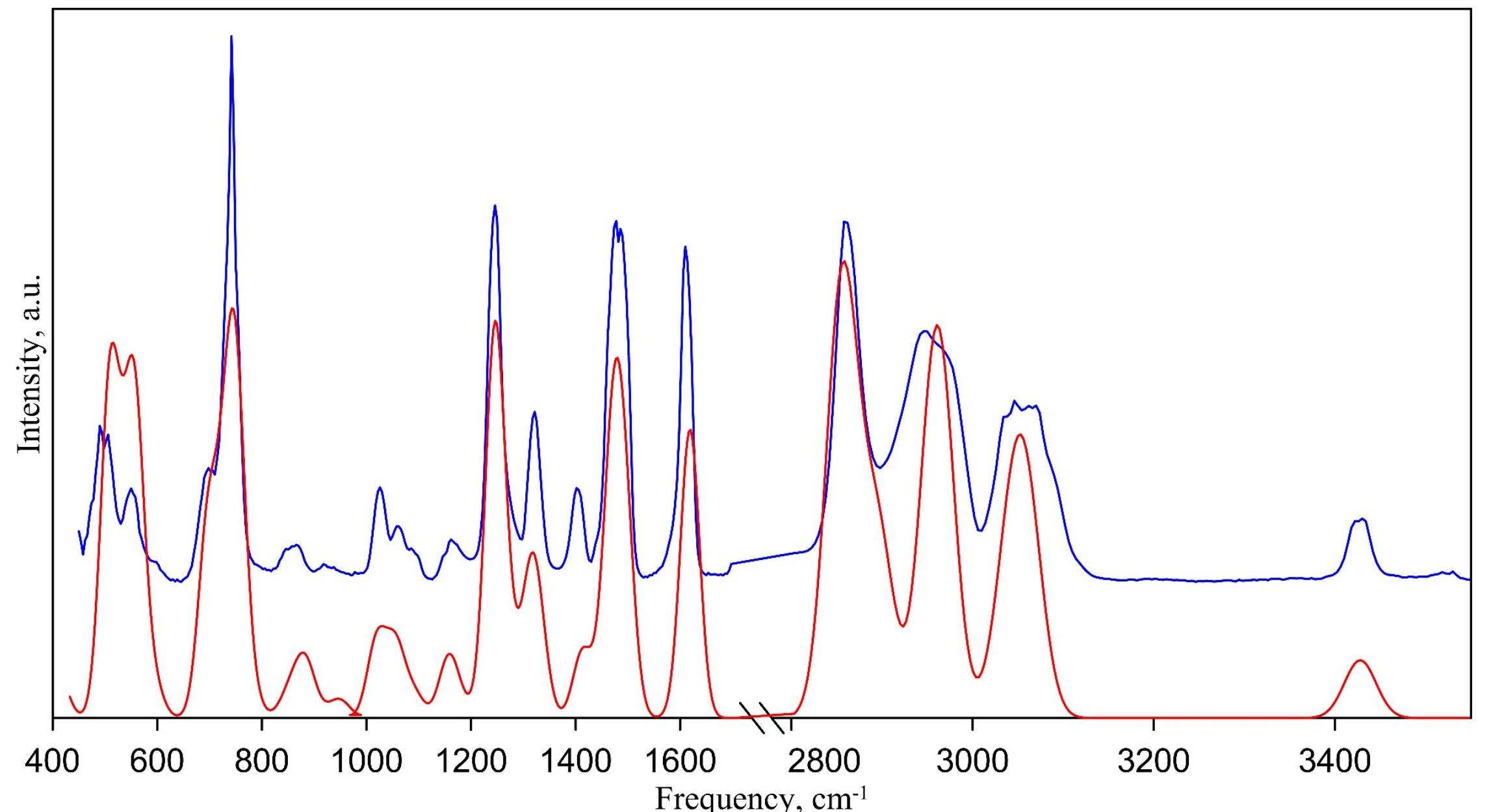

Figure S2. The comparison of IR spectra for indoline evaluated at B3LYP/cc-VPZT (D3BJ) (Gaussian broadening $25 \mathrm{~cm}^{-1}$ at half height) red line with experimental gas phase IR spectrum [NIST Standard Reference Data Program. Sadtler Research Labs. Via Webbook.nist.gov] (blue line). 


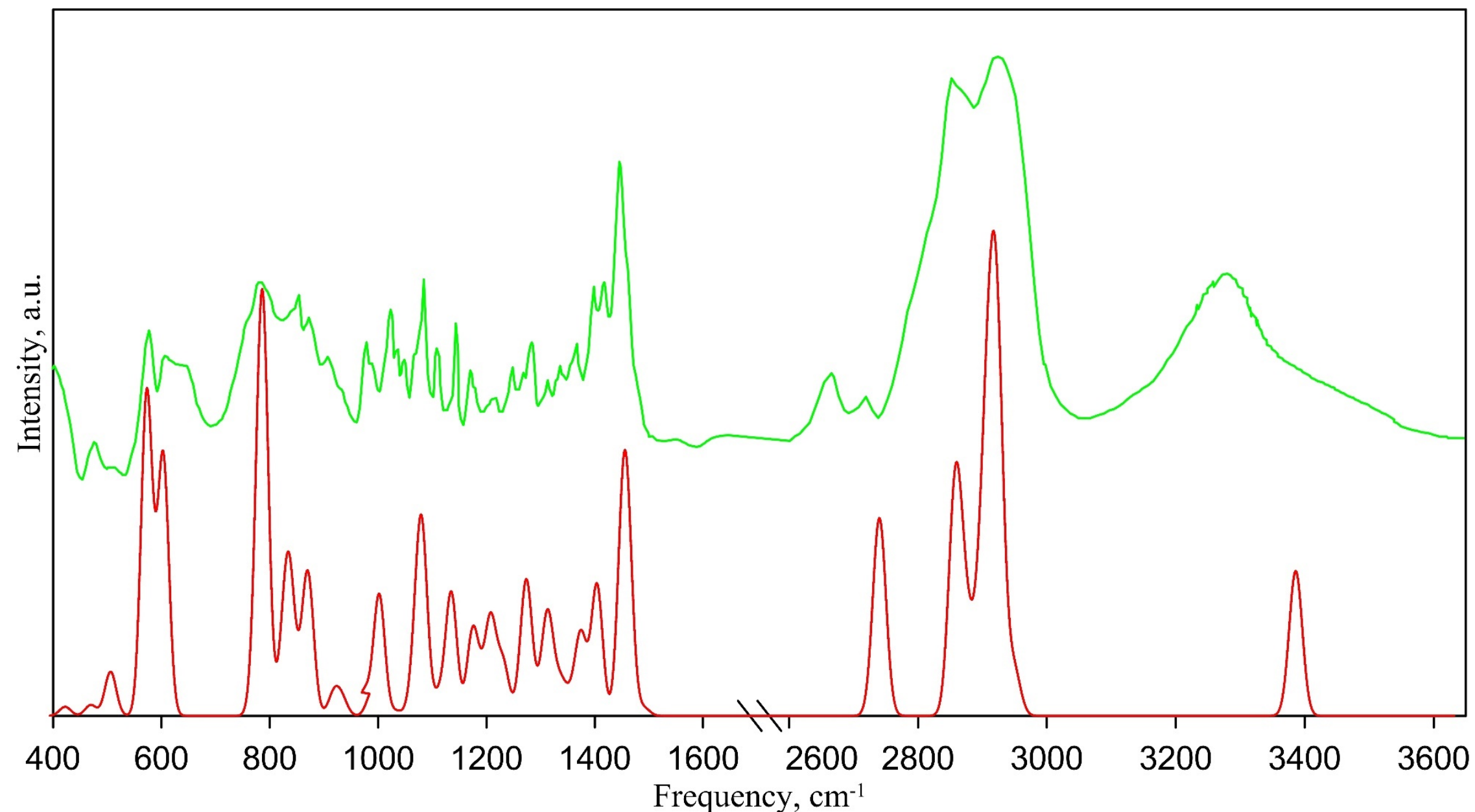

Figure S3. The comparison of IR spectra for 8H-indole evaluated at B3LYP/cc-VPZT (D3BJ) (Gaussian broadening $25 \mathrm{~cm}^{-1}$ at half height) red line with experimental liquid phase neat IR spectrum [NIST Standard Reference Data Program. Sadtler Research Labs. Via Webbook.nist.gov] (green line). 


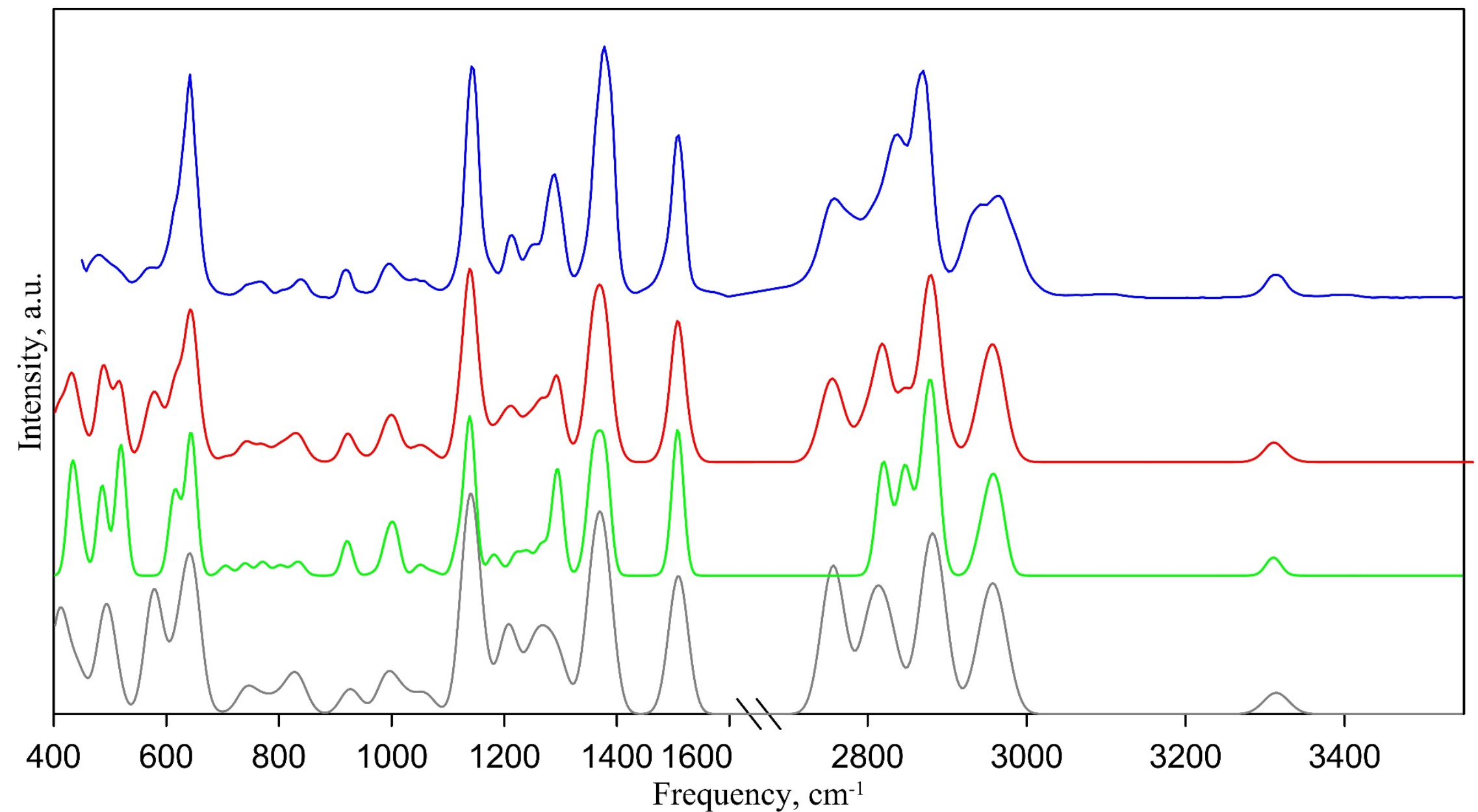

Figure S4. The comparison of IR spectra for 2-methyl indoline evaluated at B3LYP/cc-VPZT (D3BJ) (Gaussian broadening $25 \mathrm{~cm}^{-1}$ at half height): grey for conformer 1, green line for conformer 2, red line corresponds to the equilibrium mixture of conformers at $298.15 \mathrm{~K}$, experimental gas phase spectrum [NIST Standard Reference Data Program. Sadtler Research Labs. Via Webbook.nist.gov] is presented as blue line. 
Table S15. Thermodynamic properties of indole in the ideal gas state.

\begin{tabular}{rcccc}
\hline$T . \mathrm{K}$ & $S_{m}^{\mathrm{o}} . \mathrm{J} \mathrm{K}^{-1} \mathrm{~mol}^{-1}$ & $C_{p m}^{\mathrm{o}} . \mathrm{J} \mathrm{K}^{-1} \mathrm{~mol}^{-1}$ & $\frac{H-H_{0}}{T} . \mathrm{J} \mathrm{K}^{-1} \mathrm{~mol}^{-1}$ & $-\frac{G-H_{0}}{T} . \mathrm{J} \mathrm{K}^{-1} \mathrm{~mol}^{-1}$ \\
\hline 50 & 226.9 & 34.4 & 33.4 & 193.5 \\
100 & 253.3 & 44.0 & 36.0 & 217.3 \\
150 & 273.8 & 59.0 & 41.0 & 232.8 \\
200 & 293.3 & 78.0 & 47.8 & 245.5 \\
273.15 & 322.2 & 109.8 & 60.1 & 262.1 \\
298.15 & 332.3 & 120.9 & 64.7 & 267.6 \\
300 & 333.1 & 121.7 & 65.1 & 268.0 \\
320 & 341.2 & 130.4 & 68.9 & 272.3 \\
340 & 349.4 & 139.0 & 72.8 & 276.6 \\
360 & 357.6 & 147.3 & 76.7 & 280.9 \\
380 & 365.7 & 155.4 & 80.6 & 285.1 \\
400 & 373.9 & 163.2 & 84.6 & 289.4 \\
420 & 382.1 & 170.8 & 88.5 & 293.6 \\
440 & 390.2 & 178.0 & 92.4 & 302.8 \\
460 & 398.2 & 184.9 & 96.3 & 306.2 \\
480 & 406.2 & 191.5 & 100.1 & 310.3 \\
500 & 414.2 & 197.8 & 103.9 & 314.5 \\
520 & 422.1 & 203.8 & 107.6 & 318.6 \\
540 & 429.9 & 209.5 & 111.3 & 322.7 \\
560 & 437.6 & 215.0 & 114.9 & 326.8 \\
580 & 445.2 & 220.2 & 118.4 & 330.9 \\
600 & 452.8 & 225.2 & 121.9 & \\
\hline
\end{tabular}


Table S16. Thermodynamic properties of indoline in the ideal gas state.

\begin{tabular}{rcccc}
\hline$T . \mathrm{K}$ & $S_{m}^{\mathrm{o}} . \mathrm{J} \mathrm{K}^{-1} \mathrm{~mol}^{-1}$ & $C_{p m}^{\mathrm{o}} . \mathrm{J} \mathrm{K}^{-1} \mathrm{~mol}^{-1}$ & $\frac{H-H_{0}}{T} . \mathrm{J} \mathrm{K}^{-1} \mathrm{~mol}^{-1}$ & $-\frac{G-H_{0}}{T} . \mathrm{J} \mathrm{K}^{-1} \mathrm{~mol}^{-1}$ \\
\hline 50 & 228.5 & 36.7 & 34.0 & 194.6 \\
100 & 257.7 & 49.2 & 38.4 & 219.3 \\
150 & 280.4 & 64.6 & 44.5 & 236.0 \\
200 & 301.5 & 83.4 & 51.8 & 249.7 \\
273.15 & 332.2 & 115.8 & 64.5 & 267.7 \\
298.15 & 342.8 & 127.5 & 69.3 & 273.5 \\
300 & 343.6 & 128.4 & 69.6 & 274.0 \\
320 & 352.2 & 137.8 & 73.6 & 278.6 \\
340 & 360.8 & 147.1 & 77.7 & 283.2 \\
360 & 369.5 & 156.2 & 81.8 & 287.7 \\
380 & 378.2 & 165.1 & 85.9 & 292.3 \\
400 & 386.9 & 173.7 & 90.1 & 296.8 \\
420 & 395.6 & 182.1 & 94.3 & 301.3 \\
440 & 404.2 & 190.2 & 98.5 & 305.8 \\
460 & 412.8 & 198.0 & 102.6 & 310.2 \\
480 & 421.4 & 205.5 & 106.7 & 314.7 \\
500 & 430.0 & 212.7 & 110.8 & 319.1 \\
520 & 438.4 & 219.5 & 114.9 & 323.5 \\
540 & 446.8 & 226.1 & 118.9 & 328.0 \\
560 & 455.2 & 232.5 & 122.8 & 332.4 \\
580 & 463.4 & 238.5 & 126.7 & 336.7 \\
600 & 471.6 & 244.3 & 130.5 & 341.1 \\
\hline
\end{tabular}


Table S17. Thermodynamic properties of racemic equimolar mixture of $(R-, S-),(R-, R-$ ), $(S-, R-),(S-, S-)$ enantiomers of H8-indole in the ideal gas state.

\begin{tabular}{rcccc}
\hline$T . \mathrm{K}$ & $S_{m}^{\mathrm{o}} . \mathrm{J} \mathrm{K}^{-1} \mathrm{~mol}^{-1}$ & $C_{p m}^{\mathrm{o}} . \mathrm{J} \mathrm{K}^{-1} \mathrm{~mol}^{-1}$ & $\frac{H-H_{0}}{T} . \mathrm{J} \mathrm{K}^{-1} \mathrm{~mol}^{-1}$ & $-\frac{G-H_{0}}{T} . \mathrm{J} \mathrm{K}^{-1} \mathrm{~mol}^{-1}$ \\
\hline 50 & 246.7 & 43.9 & 36.8 & 209.9 \\
100 & 282.5 & 61.3 & 43.5 & 239.0 \\
150 & 310.8 & 79.3 & 51.2 & 259.6 \\
200 & 336.3 & 99.6 & 59.8 & 276.5 \\
273.15 & 372.9 & 137.1 & 74.4 & 298.5 \\
298.15 & 385.5 & 151.5 & 80.0 & 305.6 \\
300 & 386.4 & 152.5 & 80.4 & 306.0 \\
320 & 396.7 & 164.4 & 85.1 & 311.6 \\
340 & 407.0 & 176.3 & 89.9 & 317.1 \\
360 & 417.4 & 188.2 & 94.9 & 322.5 \\
380 & 427.9 & 200.0 & 99.9 & 328.0 \\
400 & 438.5 & 211.6 & 105.0 & 333.4 \\
420 & 449.0 & 222.9 & 110.2 & 338.9 \\
440 & 459.7 & 234.0 & 115.4 & 344.3 \\
460 & 470.3 & 244.7 & 120.6 & 349.7 \\
480 & 480.9 & 255.1 & 125.8 & 355.1 \\
500 & 491.6 & 265.2 & 131.0 & 360.5 \\
520 & 502.2 & 274.9 & 136.2 & 366.0 \\
540 & 512.7 & 284.3 & 141.3 & 371.4 \\
560 & 523.2 & 293.3 & 146.4 & 376.8 \\
580 & 533.6 & 302.0 & 151.4 & 382.2 \\
600 & 544.1 & 310.0 & 156.4 & 387.7 \\
\hline
\end{tabular}


Table S18. Thermodynamic properties of 2-methyl-indole in the ideal gas state from reference [18 Chi]

\begin{tabular}{rccc}
\hline$T . \mathrm{K}$ & $S_{m}^{\mathrm{o}} . \mathrm{J} \mathrm{K}^{-1} \mathrm{~mol}^{-1}$ & $C_{p m}^{\mathrm{o}} . \mathrm{J} \mathrm{K}^{-1} \mathrm{~mol}^{-1}$ & $\frac{H-H_{298.15}}{T} . \mathrm{J} \mathrm{K}^{-1} \mathrm{~mol}^{-1}$ \\
\hline 298.15 & 368.8 & 146.1 & 0.000 \\
300 & 369.8 & 147.0 & 0.9063 \\
320 & 379.5 & 156.5 & 10.33 \\
340 & 389.3 & 165.9 & 19.21 \\
360 & 399.1 & 175.1 & 27.62 \\
380 & 408.8 & 184.1 & 35.62 \\
400 & 418.4 & 192.8 & 43.26 \\
420 & 428.1 & 201.3 & 50.59 \\
440 & 437.6 & 209.4 & 57.62 \\
460 & 447.1 & 217.2 & 64.39 \\
480 & 456.5 & 224.7 & 70.91 \\
500 & 465.8 & 231.9 & 77.21 \\
520 & 475.0 & 238.8 & 83.29 \\
540 & 484.2 & 245.4 & 89.18 \\
560 & 493.2 & 251.8 & 94.87 \\
580 & 502.2 & 257.8 & 100.4 \\
600 & 511.0 & 263.7 & 105.7 \\
620 & 519.7 & 269.3 & 110.9 \\
640 & 528.4 & 274.6 & 116.0 \\
660 & 536.9 & 279.8 & 120.8 \\
680 & 545.3 & 284.7 & 125.6 \\
700 & 553.6 & 289.5 & 130.2 \\
\hline
\end{tabular}


Table S19. Thermodynamic properties of equimolar racemic mixture of $R$ - and $S$ enantiomers of 2-methyl-indoline in the ideal gas state.

\begin{tabular}{|c|c|c|c|c|}
\hline$T, \mathrm{~K}$ & $S_{m}^{\mathrm{o}}, \mathrm{J} \mathrm{K}^{-1} \mathrm{~mol}^{-1}$ & $C_{p m}^{\mathrm{o}}, \mathrm{J} \mathrm{K}^{-1} \mathrm{~mol}^{-1}$ & $\frac{H-H_{0}}{T}, \mathrm{~J} \mathrm{~K}^{-1} \mathrm{~mol}^{-1}$ & $-\frac{G-H_{0}}{T}, \mathrm{~J} \mathrm{~K}^{-1} \mathrm{~mol}^{-1}$ \\
\hline 50 & 247.7 & 47.3 & 37.0 & 210.7 \\
\hline 100 & 286.1 & 67.0 & 45.9 & 240.2 \\
\hline 150 & 317.7 & 91.1 & 56.6 & 261.1 \\
\hline 200 & 347.5 & 117.8 & 68.4 & 279.0 \\
\hline 273.15 & 390.4 & 159.7 & 87.2 & 303.2 \\
\hline 298.15 & 405.0 & 174.0 & 93.9 & 311.1 \\
\hline 300 & 406.0 & 175.0 & 94.4 & 311.7 \\
\hline 320 & 417.7 & 186.2 & 99.7 & 318.0 \\
\hline 340 & 429.3 & 197.1 & 105.1 & 324.2 \\
\hline 360 & 440.9 & 207.6 & 110.5 & 330.3 \\
\hline 380 & 452.4 & 217.8 & 115.9 & 336.5 \\
\hline 400 & 463.8 & 227.6 & 121.3 & 342.5 \\
\hline 420 & 475.1 & 236.9 & 126.5 & 348.6 \\
\hline 440 & 486.4 & 245.8 & 131.8 & 354.6 \\
\hline 460 & 497.5 & 254.3 & 136.9 & 360.6 \\
\hline 480 & 508.5 & 262.5 & 142.0 & 366.5 \\
\hline 500 & 519.3 & 270.2 & 146.9 & 372.4 \\
\hline 520 & 530.1 & 277.6 & 151.8 & 378.3 \\
\hline 540 & 540.7 & 284.6 & 156.6 & 384.1 \\
\hline 560 & 551.2 & 291.3 & 161.3 & 389.9 \\
\hline 580 & 561.5 & 297.8 & 165.9 & 395.6 \\
\hline 600 & 571.7 & 303.9 & 170.4 & 401.3 \\
\hline
\end{tabular}


Table S20. Thermodynamic properties of racemic equimolar mixture of $(R-, S-),(R-, R-),(S-, R-$ ), ( $S$-,S-) enantiomers including ( $R$-, $S$ - enantiomers of C2 position) of H8-2-methyl indole in the ideal gas state.

\begin{tabular}{|c|c|c|c|c|}
\hline$T, \mathrm{~K}$ & $S_{m}^{\mathrm{o}}, \mathrm{J} \mathrm{K}^{-1} \mathrm{~mol}^{-1}$ & $C_{p m}^{\mathrm{o}}, \mathrm{J} \mathrm{K}^{-1} \mathrm{~mol}^{-1}$ & $\frac{H-H_{0}}{T}, \mathrm{~J} \mathrm{~K}^{-1} \mathrm{~mol}^{-1}$ & $-\frac{G-H_{0}}{T}, \mathrm{~J} \mathrm{~K}^{-1} \mathrm{~mol}^{-1}$ \\
\hline 50 & 260.5 & 46.7 & 38.6 & 221.9 \\
\hline 100 & 299.5 & 69.3 & 47.1 & 252.4 \\
\hline 150 & 332.2 & 93.9 & 57.5 & 274.7 \\
\hline 200 & 362.7 & 119.5 & 68.7 & 294.0 \\
\hline 273.15 & 406.1 & 162.6 & 86.7 & 319.4 \\
\hline 298.15 & 421.0 & 178.6 & 93.3 & 327.7 \\
\hline 300 & 422.2 & 179.8 & 93.8 & 328.3 \\
\hline 320 & 434.2 & 193.0 & 99.3 & 334.9 \\
\hline 340 & 446.3 & 206.1 & 104.9 & 341.4 \\
\hline 360 & 458.4 & 219.2 & 110.6 & 347.8 \\
\hline 380 & 470.6 & 232.1 & 116.4 & 354.2 \\
\hline 400 & 482.9 & 244.8 & 122.2 & 360.6 \\
\hline 420 & 495.1 & 257.3 & 128.1 & 367.0 \\
\hline 440 & 507.4 & 269.3 & 134.0 & 373.4 \\
\hline 460 & 519.6 & 281.0 & 139.9 & 379.7 \\
\hline 480 & 531.8 & 292.4 & 145.7 & 386.1 \\
\hline 500 & 544.0 & 303.3 & 151.6 & 392.4 \\
\hline 520 & 556.1 & 313.9 & 157.4 & 398.7 \\
\hline 540 & 568.1 & 324.1 & 163.1 & 405.0 \\
\hline 560 & 580.1 & 333.9 & 168.8 & 411.3 \\
\hline 580 & 591.9 & 343.3 & 174.4 & 417.6 \\
\hline 600 & 603.7 & 352.4 & 179.9 & 423.8 \\
\hline
\end{tabular}




\section{NMR and GC-MS analysis}

NMR: ECX 400, JEOL.

Solvent: Chloroform-D (with TMS), VWR.

Note: ${ }^{1} \mathrm{H}$ NMR spectrum fitting is referenced to the solvent residual peak (chloroform, $7.26 \mathrm{ppm}$ ).

GC-MS: SCION SQ/451 GC, Bruker.

Column: Rtx-225; Length: $30 \mathrm{~m}$; ID: $0.22 \mathrm{~mm}$; $\mathrm{d}_{\mathrm{f}}: 0.25 \mu \mathrm{m}$.

PS: The purity of all the samples were determined by GC-FID (Varina 3900, CP-Sil PONA CB: $50 \mathrm{~m}, 0.21$ $\mathrm{mm}, 0.6 \mu \mathrm{m})$.

\section{Indole}

${ }^{1} \mathrm{H}$ NMR (400 MHz, Chloroform-d) $\delta 8.08$ (s, 1H), 7.68 (t, $\left.J=7.0 \mathrm{~Hz}, 1 \mathrm{H}\right), 7.40$ (d, $J=8.1 \mathrm{~Hz}$, $1 \mathrm{H}), 7.29-7.10$ (m, 3H), 6.58 (t, $J=2.5 \mathrm{~Hz}, 1 \mathrm{H})$.

EI-MS (m/z) (10 $\left.{ }^{9} \mathrm{GCps}\right): 116.7$ (M+2 2.021$) ; 89.9$ (0.9404); 62.4 (0.1868).

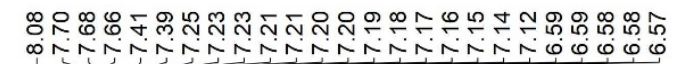

Indole

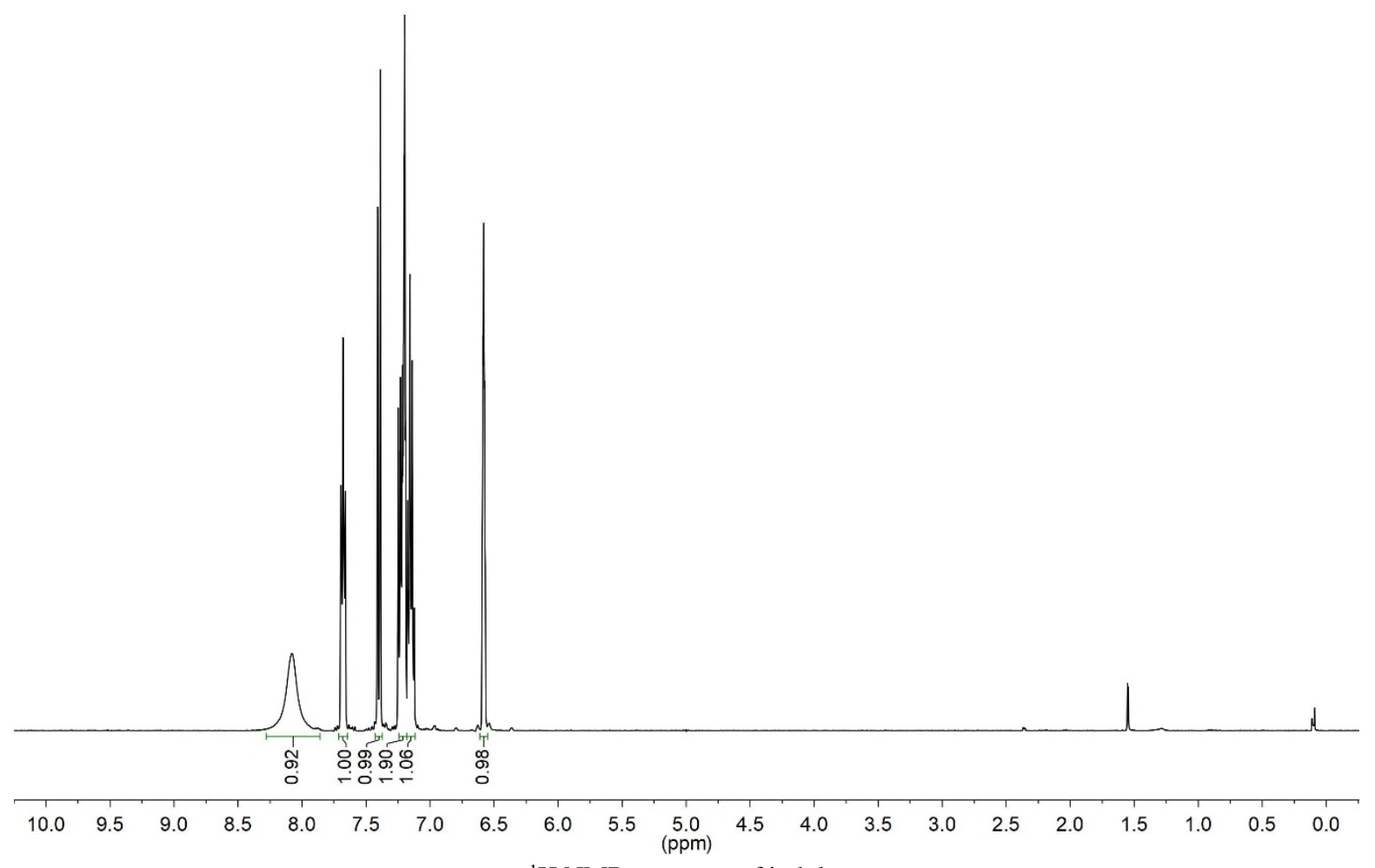

${ }^{1} \mathrm{H}$ NMR spectrum of indole. 


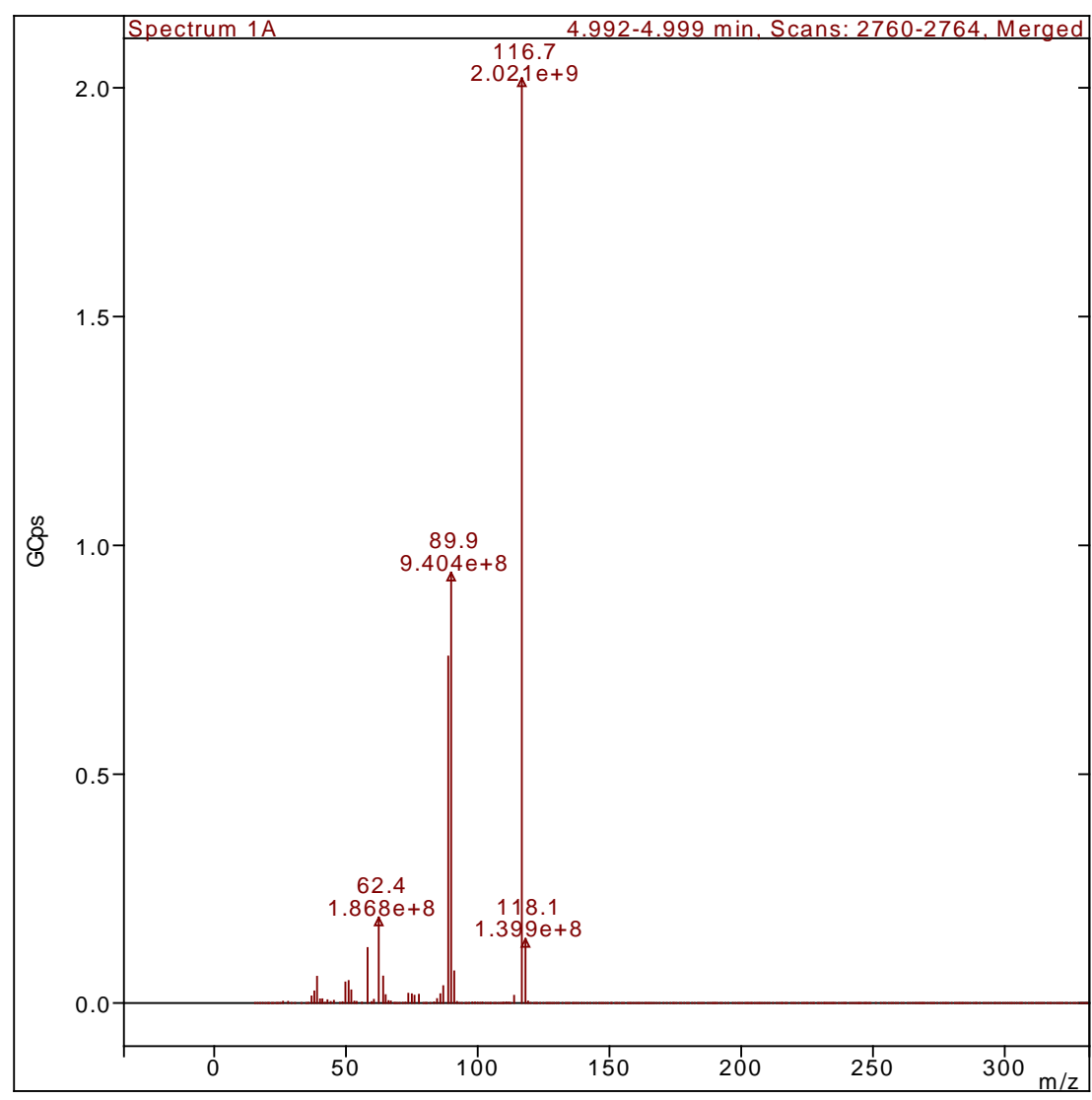

EI spectrum of indole. 


\section{Indoline}

${ }^{1} \mathrm{H}$ NMR (400 MHz, Chloroform- $d$ ) $\delta 7.13$ (d, $\left.J=7.3 \mathrm{~Hz}, 1 \mathrm{H}\right), 7.03$ (t, $J=7.6 \mathrm{~Hz}, 1 \mathrm{H}$ ), 6.72 (t, $J=7.3 \mathrm{~Hz}, 1 \mathrm{H}), 6.66$ (d, $J=7.8 \mathrm{~Hz}, 1 \mathrm{H}), 3.55$ (t, $J=8.4 \mathrm{~Hz}, 2 \mathrm{H}), 3.04(\mathrm{t}, J=8.4 \mathrm{~Hz}, 2 \mathrm{H})$. EI-MS (m/z) (10 $\left.{ }^{9} \mathrm{GCps}\right): 119.0\left(\mathrm{M}^{+} ; 1.498\right) ; 117.7$ ([M-H] $\left.]^{+} ; 2.720\right) ; 90.7$ (0.6932).

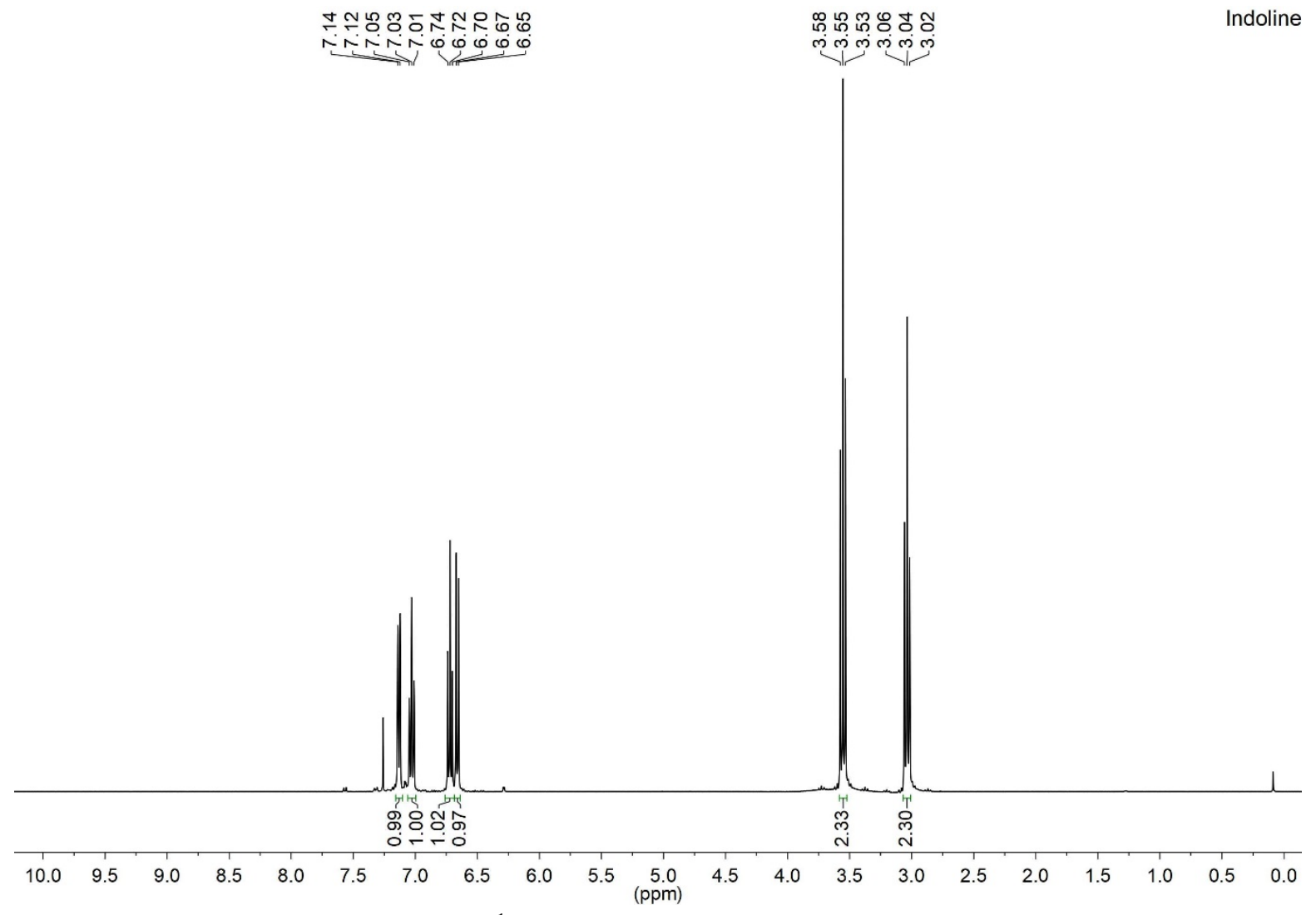

${ }^{1} \mathrm{H}$ NMR spectrum of indoline.

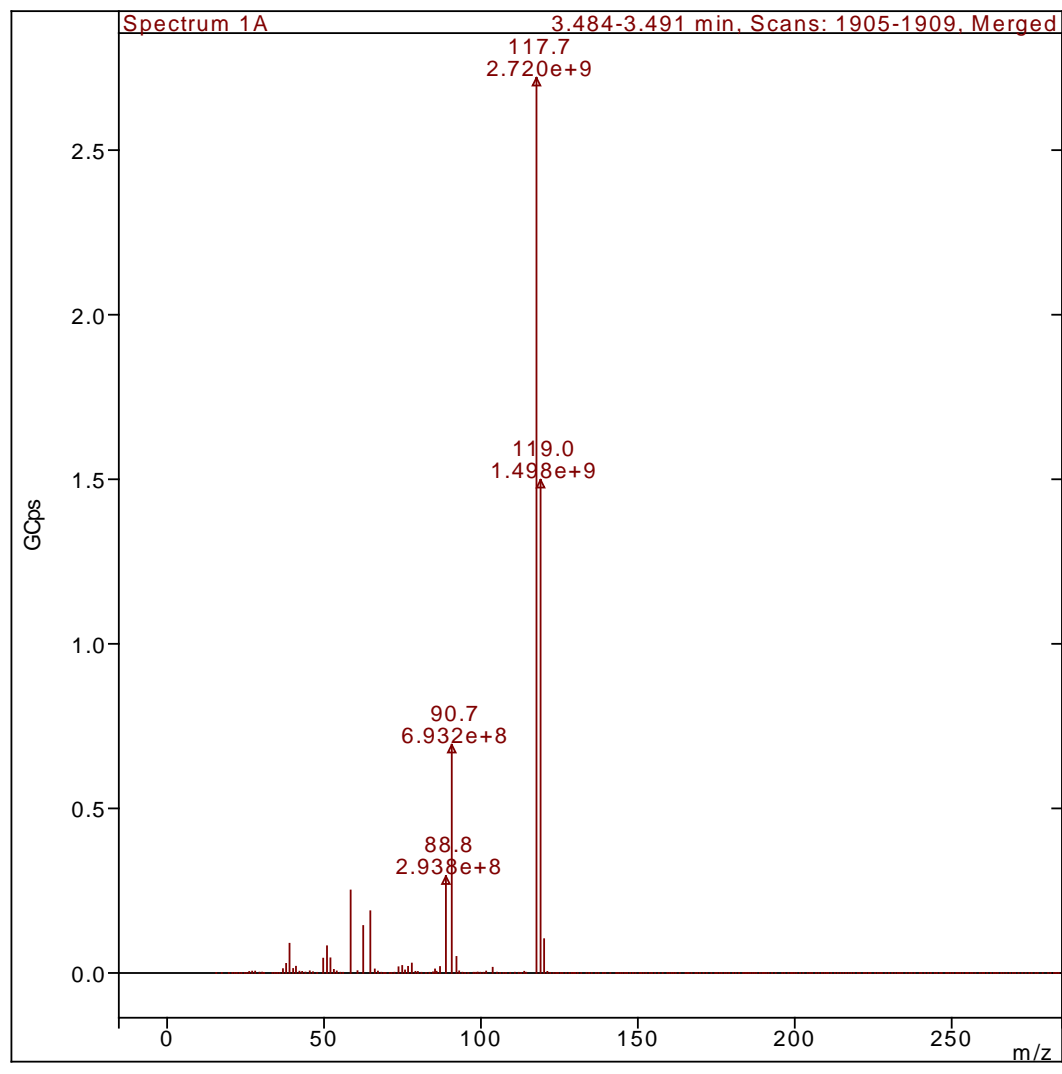

EI spectrum of indoline. 


\section{H-Indole}

${ }^{1} \mathrm{H}$ NMR (400 MHz, Chloroform-d) $\delta 3.00$ (dd, $J=20.2,4.0 \mathrm{~Hz}, 1 \mathrm{H}$ ), 2.89 (dd, $J=9.7,5.3 \mathrm{~Hz}$, 1H), 2.54 (s, 1H), $2.17-1.66$ (m, 3H), $1.66-1.43$ (m, 4H), $1.43-0.97$ (m, 5H). EI-MS (m/z) (10 9 GCps): 124.5 ( $\left.\mathrm{M}^{+} ; 0.4603\right) ; 81.8$ (4.130); 67.7 (0.5104); 56.0 (0.1642).

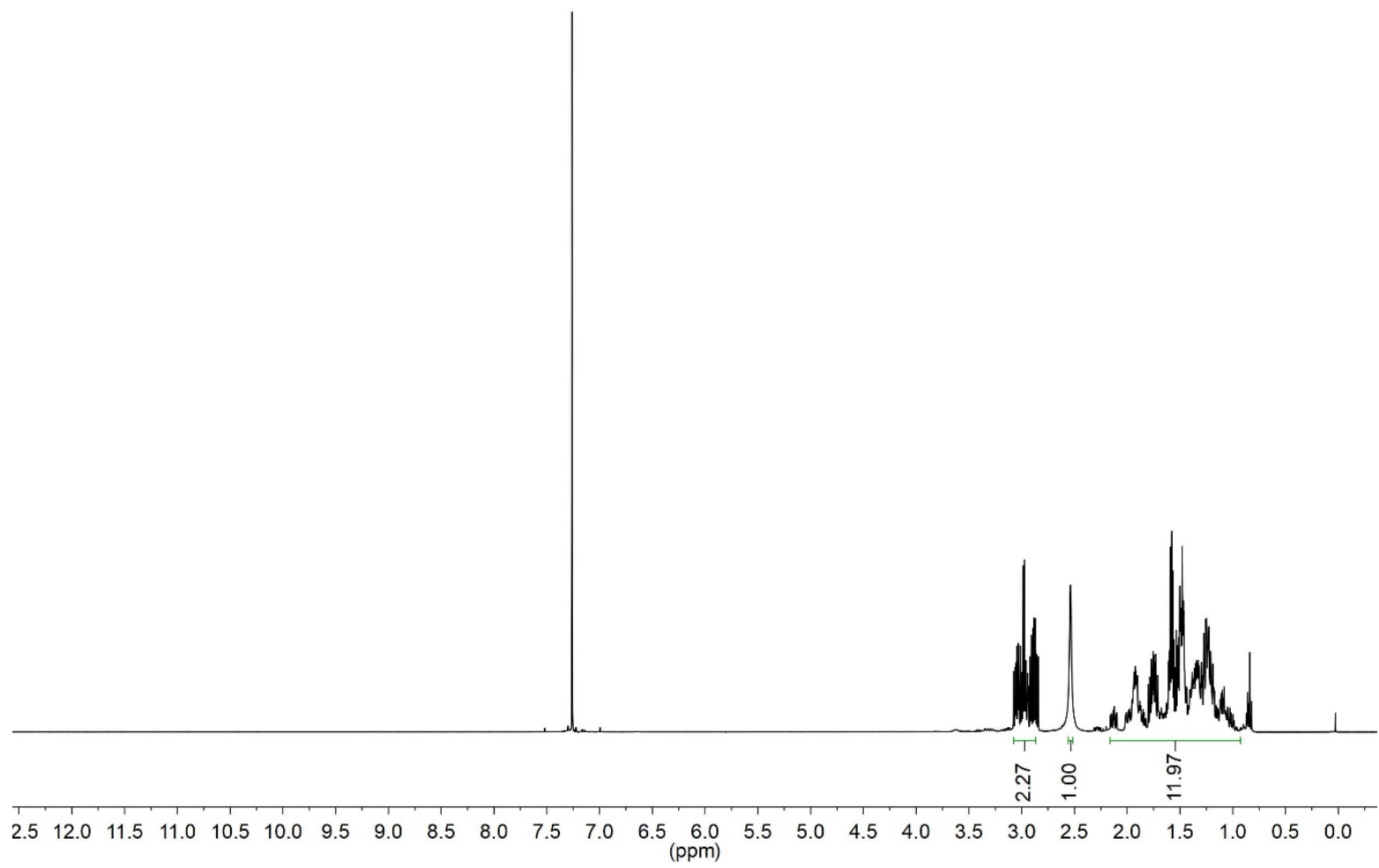

${ }^{1} \mathrm{H}$ NMR spectrum of $8 \mathrm{H}$-indole. (stereoisomers).

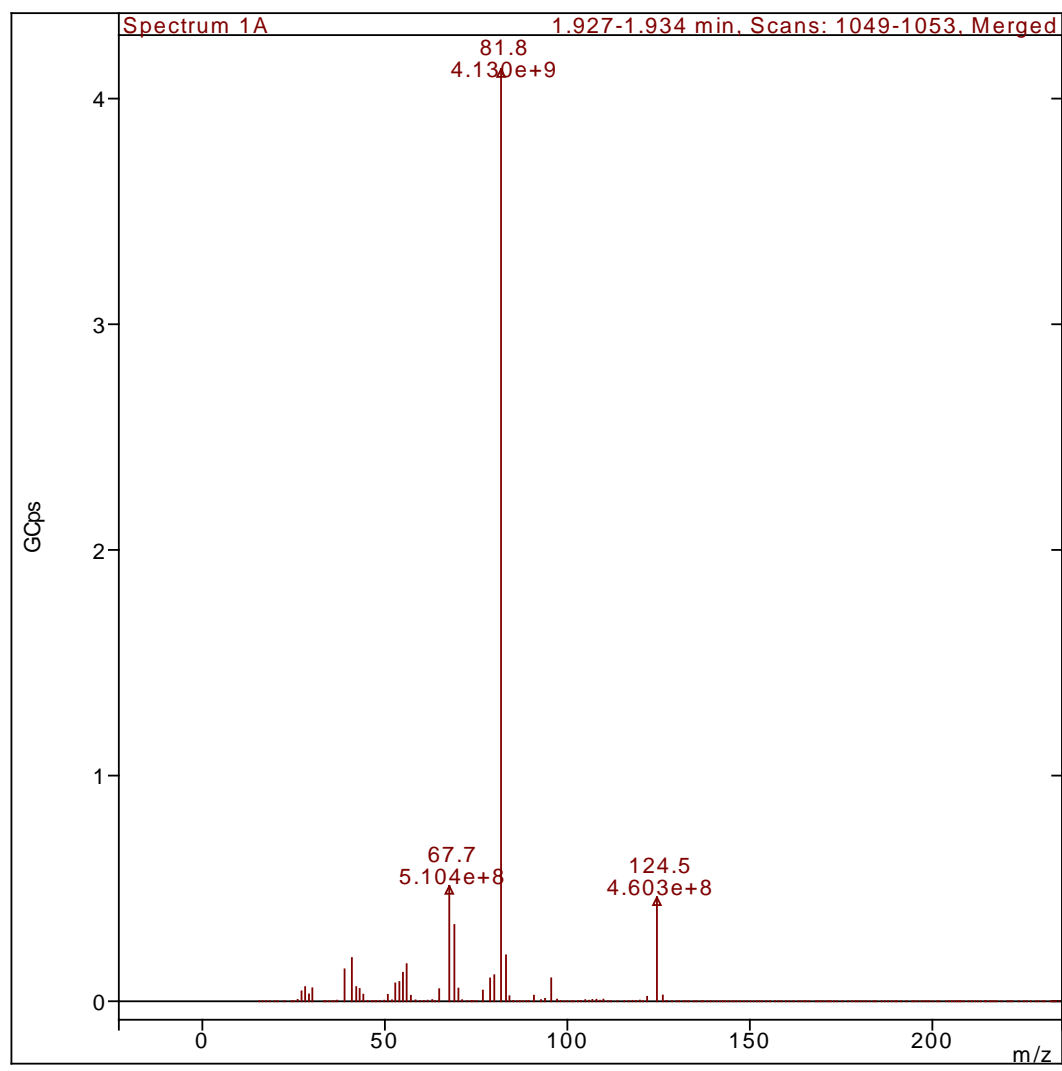

EI spectrum of 8H-indole. 


\section{2-Methylindole}

${ }^{1} \mathrm{H}$ NMR (400 MHz, Chloroform-d) $\delta 7.81$ (s, 1H), 7.51 (t, $\left.J=6.1 \mathrm{~Hz}, 1 \mathrm{H}\right), 7.26$ (t, $J=7.6 \mathrm{~Hz}$, $1 \mathrm{H}), 7.18-6.99$ (m, 2H), 6.21 (d, $J=3.4 \mathrm{~Hz}, 1 \mathrm{H}), 2.44$ (d, $J=2.5 \mathrm{~Hz}, 3 \mathrm{H}$ ).

EI-MS (m/z) (109 GCps): $131.0\left(\mathrm{M}^{+} ; 2.483\right) ; 129.8$ ([M-H] $\left.]^{+} ; 129.8\right) ; 102.3$ (0.1618); 88.8 (0.1588); 76.7 (0.4892).

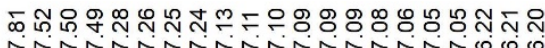

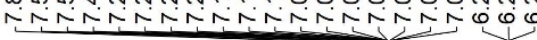

2-Methylindole

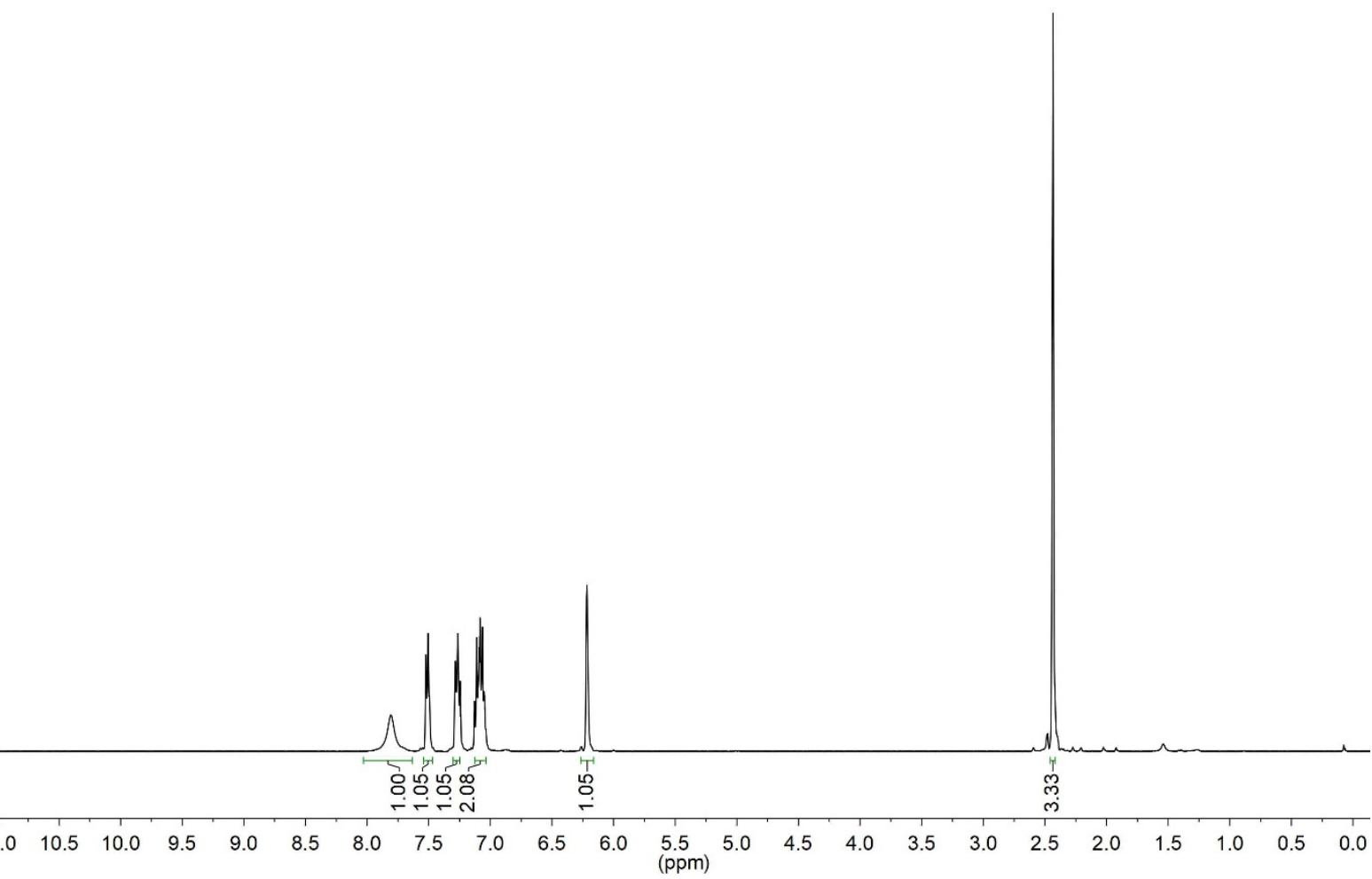

${ }^{1} \mathrm{H}$ NMR spectrum of 2-methylindole. 


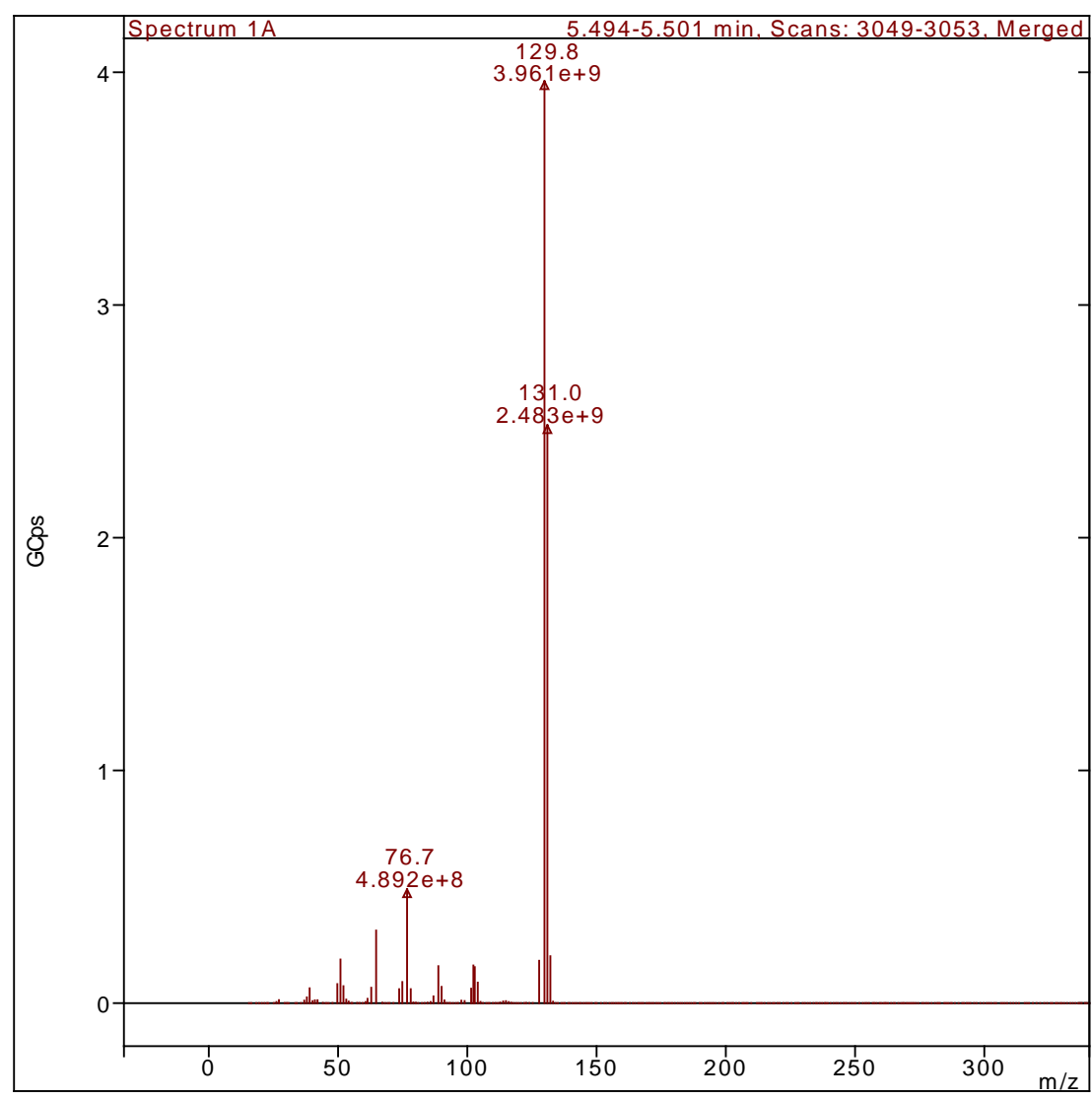

EI spectrum of 2-methylindole. 


\section{2-Methylindoline}

${ }^{1} \mathrm{H}$ NMR (400 MHz, Chloroform-d) $\delta 7.11(\mathrm{t}, J=6.0 \mathrm{~Hz}, 1 \mathrm{H}), 7.05$ (t, $\left.J=7.6 \mathrm{~Hz}, 1 \mathrm{H}\right), 6.82-$ 6.68 (m, 1H), 6.63 (dd, $J=7.8,4.3 \mathrm{~Hz}, 1 \mathrm{H}), 4.02$ (qd, $J=8.3,7.1,2.8 \mathrm{~Hz}, 1 \mathrm{H}$ ), $3.81(\mathrm{~s}, 1 \mathrm{H})$, 3.17 (ddd, $J=15.1$, 8.5, 4.2 Hz, 1H), $2.85-2.53$ (m, 1H), 1.32 (dt, $J=6.3,3.0 \mathrm{~Hz}, 3 \mathrm{H}$ ).

EI-MS (m/z) (109 GCps): 132.7 (M+; 2.329); 117.7 (6.788); 90.7 (1.486); 76.8 (0.3242).

2-Methylindoline

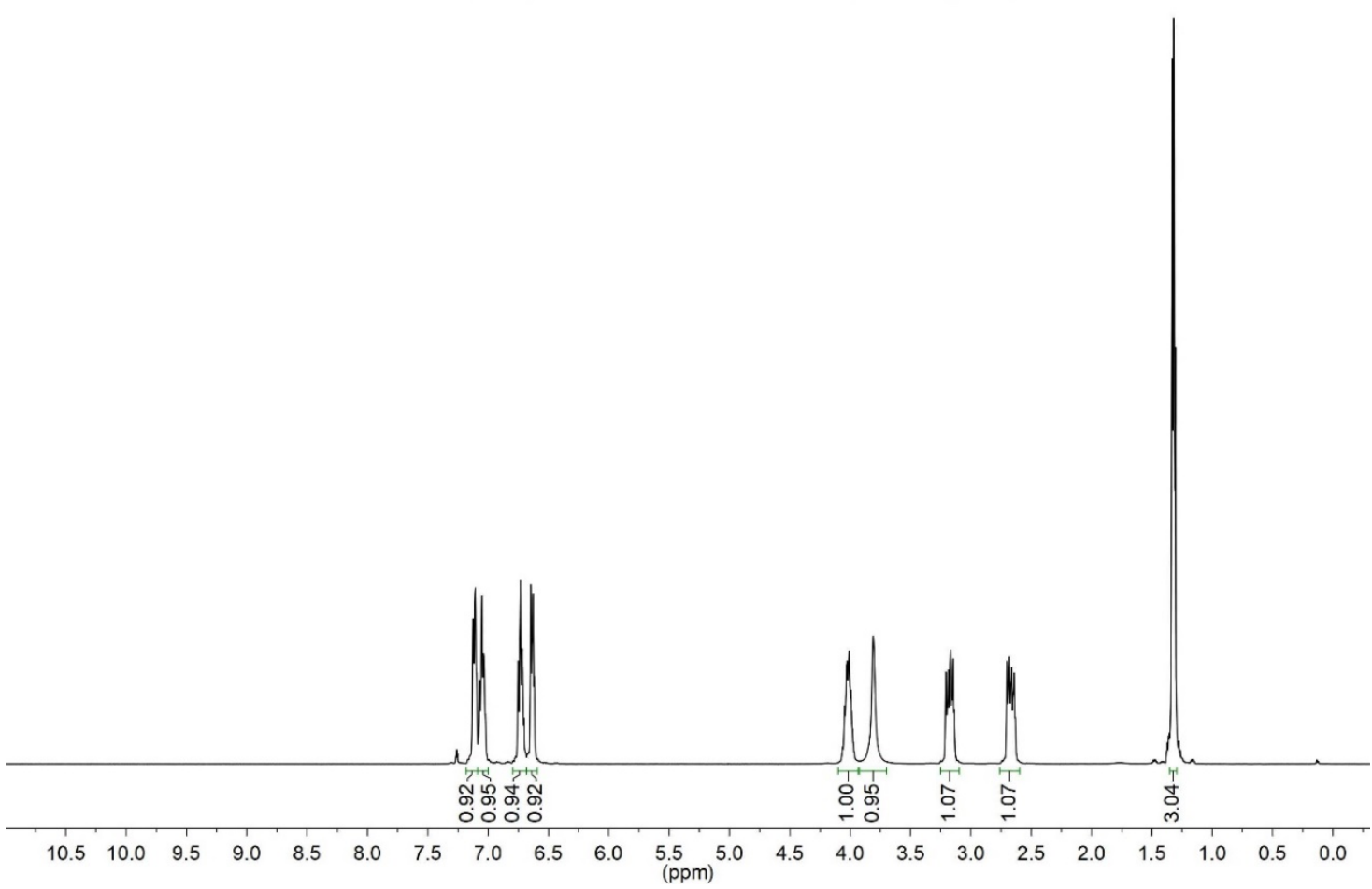

${ }^{1} \mathrm{H}$ NMR spectrum of 2-methylindoline.

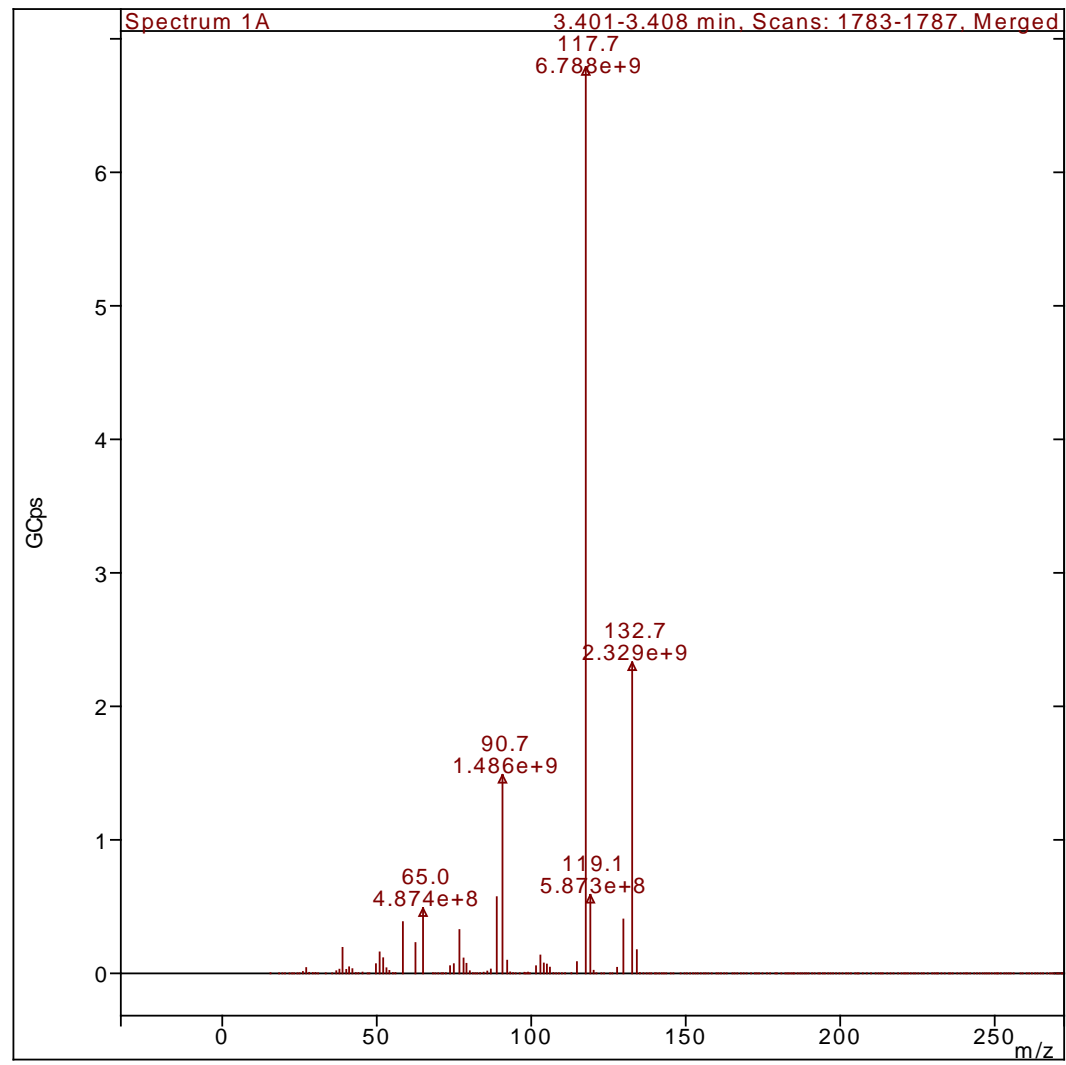

EI spectrum of 2-methylindoline. 


\section{H-2-Methylindole}

${ }^{1} \mathrm{H}$ NMR (400 MHz, Chloroform-d) $\delta 3.59-2.13(\mathrm{~m}, 2 \mathrm{H}), 2.10-1.67$ (m, 2H), $1.67-1.40$ (m, 5H), $1.40-1.17$ (m, 5H), 1.07 (dd, $J=6.3,1.6 \mathrm{~Hz}, 3 \mathrm{H})$.

EI-MS (m/z) (109 GCps): 138.6 (M+1 0.1413$) ; 123.9$ (0.4408); 95.8 (1.161); 80.8 (0.2255); 67.6 (0.1036).

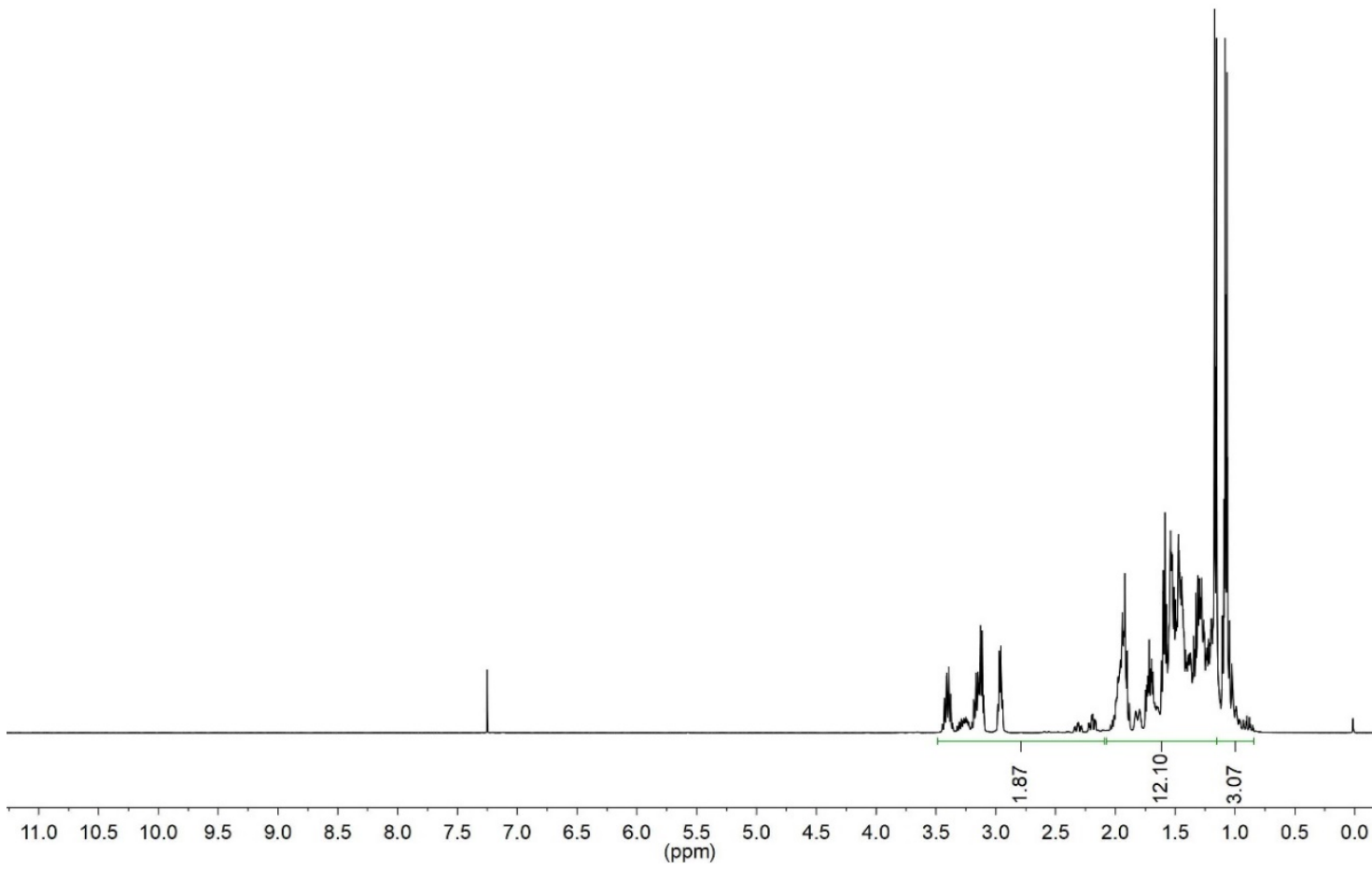

${ }^{1} \mathrm{H}$ NMR spectrum of 8H-2-methylindole (stereoisomers).

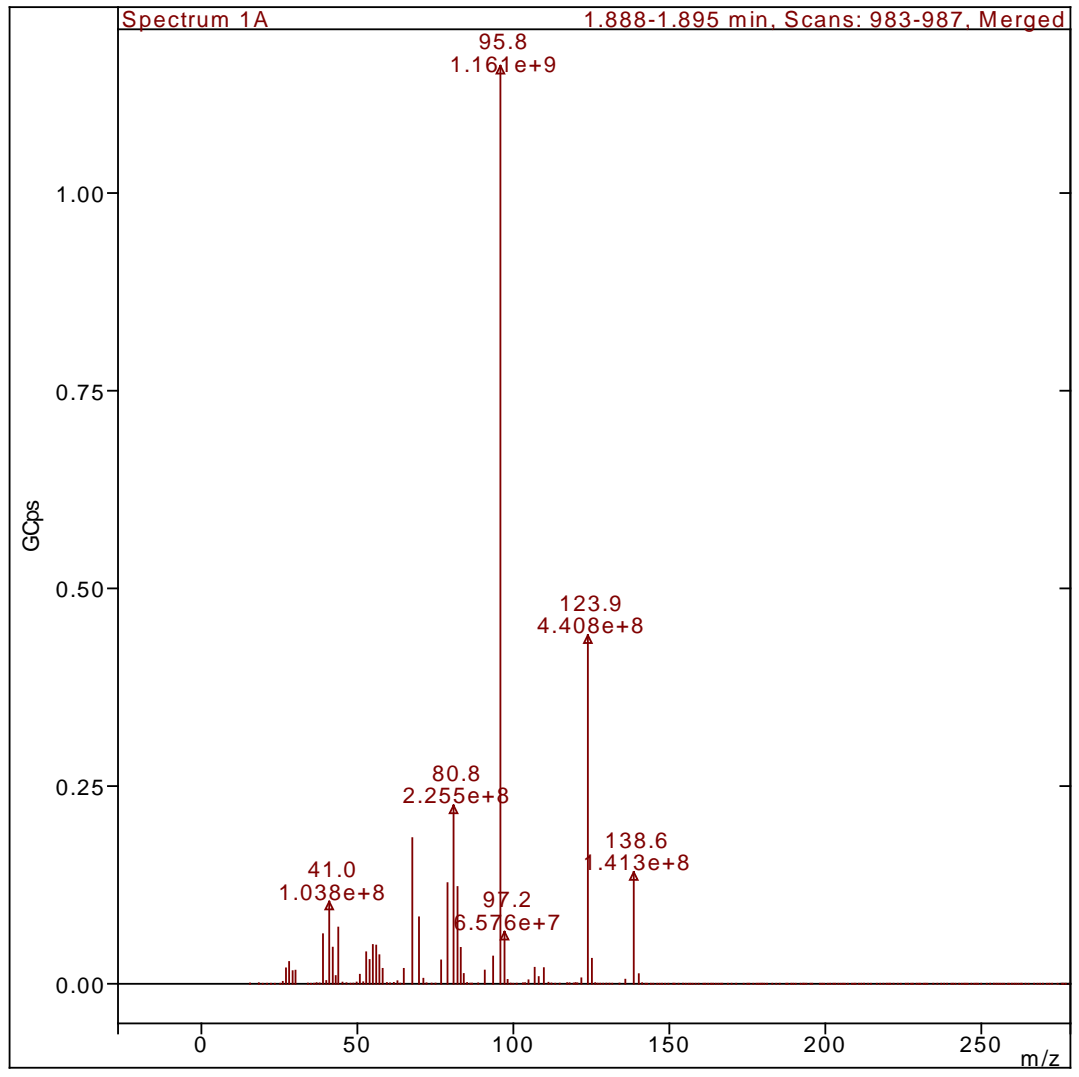

EI spectrum of 8H-2-methylindole. 


\section{References for the ESI}

[S1]

[72go]

[SA] [12br]

[18chi]

[99ver]

[56hub]

[79olo]

[71dit]

[05iri]

[76McQ] [17acr]

[14gob]

$[58 \mathrm{kov}]$

V. N. Emel`yanenko, D.H. Zaitsau, E. Shoifet, F. Meurer, S.P. Verevkin, C. Schick, C. Held, Benchmark thermochemistry for biologically relevant adenine and cytosine. A combined experimental and theoretical study, J. Phys. Chem. A 119 (2015) 9680-9691. S.P. Verevkin, V.N. Emel yanenko, Transpiration method: vapor pressures and enthalpies of vaporization of some low-boiling esters, Fluid Phase Equilib. 266 (2008) 64-75.

S.P. Verevkin, A.Y. Sazonova, V.N. Emel yanenko, D.H. Zaitsau, M.A. Varfolomeev, B.N. Solomonov, K.V. Zherikova, Thermochemistry of halogen-substituted methylbenzenes, J. Chem. Eng. Data 60 (2015) 89-103.

V.N. Emel'yanenko, S.P. Verevkin, Benchmark thermodynamic properties of 1,3propanediol: comprehensive experimental and theoretical study, J. Chem. Thermodyn. 85 (2015) 111-119.

S.P Verevkin, C. Schick, Substituent effects on the benzene ring. Determination of the intra-molecular interactions of substituents in tert-alkyl substituted catechols from thermochemical measurements, J. Chem. Eng. Data 45 (2000) 946-952.

V.N. Emel yanenko, S.P. Verevkin, A. Heintz, The gaseous enthalpy of formation of the ionic liquid 1-butyl-3-methyl-imidazolium dicyanoamide from combustion calorimetry, vapor pressure measurements, and ab initio calculations, J. Amer. Chem. Soc. 129 (2007) 3930-3937.

W. Good Enthalpies of Combustion of Nine Organic Nitrogen Compounds Related to Petroleum Journal of Chemical and Engineering Data, Vol. 17, No. 1, 1972. https://doi.org/10.1021/je60052a038

https://www.sigmaaldrich.com/

Braun, J. V.; Cyclic Imines. V. Dihydro-p-indole and p-Indole, Berichte der Deutschen Chemischen Gesellschaft 1912, V45, P1274-88

Robert D. Chirico , Eugene Paulechka, Ala Bazyleva, Andrei F. Kazakov, Thermodynamic properties of 2-methylindole: Experimental and computational results for gas-phase entropy and enthalpy of formation, J. Chem. Thermodynamics 125 (2018) 257-270

S.P. Verevkin, Thermochemistry of phenols: quantification of the ortho-, para-, and meta-interactions in tert-alkyl substituted phenols, J. Chem. Thermodyn. 31 (1999) 559585.

W.N. Hubbard. D.W. Scott. G. Waddington. Standard states and corrections for combustions in a bomb at constant volume. in: F.D. Rossini (Ed.). Experimental Thermochemistry. Interscience Publishers. New York. 1956. pp. 75-128.

G. Olofsson. Assignment of uncertainties. in: S. Sunner. M. Månsson (Eds.). Combustion Calorimetry: Experimental Chemical Thermodynamics. Pergamon. New York. 1979. pp. 137-161.

R. Ditchfield, W.J. Hehre, J.A. Pople, Self-consistent molecular-orbital methods. IX. An extended gaussian-type basis for molecular-orbital studies of organic molecules, J. Chem. Phys. 54 (1971) 724.

K.K. Irikura, R.D. Johnson III, R.N. Kacker. Uncertainties in scaling factors for ab initio vibrational frequencies, J. Phys. Chem. 109 (2005) 8430-8437. D.A. McQuarrie, Statistical mechanics. Harper \& Row: New York, 1976.

W. Acree Jr., J.S. Chickos, Phase transition enthalpy measurements of organic and organometallic compounds and ionic liquids. Sublimation, vaporization, and fusion enthalpies from 1880 to 2015. Part 2. C11-C192, J. Phys. Chem. Ref. Data 46 (2017) 013104.

C. Gobble, J.S. Chickos, S.P. Verevkin, Vapor pressures and vaporization enthalpies of a series of dialkyl phthalates by correlation gas chromatography, J. Chem. Eng. Data 59 (2014) 1353-1365.

E. Kovats. Gas-chromatographische charakterisierung organischer verbindungen. Teil 1: retentionsindices aliphatischer halogenide. alkohole. aldehyde und ketone. Helv. Chim. Acta 41 (1958) 1915-1932. 
[pub] https://pubchem.ncbi.nlm.nih.gov/

[M85] Majer, V.; Svoboda, V., Enthalpies of Vaporization of Organic Compounds: A Critical Review and Data Compilation, Blackwell Scientific Publications, Oxford, 1985, 300.

[P86] Pedley, J.P.; Naylor, R.D.; Kirby, S.P. Thermochemical Data of Organic Compounds, 2nd Ed., Chapman and Hall, London, 1986.

[11ver-eme_1] Sergey P. Verevkin, Vladimir N. Emel'yanenko, Andrey A. Pimerzin, Elena E. Vishnevskaya, Thermodynamic Analysis of Strain in the Five-Membered Oxygen and Nitrogen Heterocyclic Compounds. J. Phys. Chem. A, 2011, 115, 1992-2004.

[11ver-eme_2] Sergey P. Verevkin, Vladimir N. Emel'yanenko. Andrey A. Pimerzin, Elena E. Vishnevskaya Thermodynamic Analysis of Strain in Heteroatom Derivatives of Indene. J. Phys. Chem. A 2011, 115, 12271-12279.

[06ver] S.P. Verevkin, Vapour pressures and enthalpies of vaporization of a series of the linear n-alkyl-benzenes, J. Chem. Thermodyn. 38 (2006) 1111-1123.

[11ver-eme_1] Sergey P. Verevkin and Vladimir N. Emel'yanenko; Andrey A. Pimerzin and Elena E. Vishnevskaya: Thermodynamic Analysis of Strain in the Five-Membered Oxygen and Nitrogen Heterocyclic Compounds; J. Phys. Chem. A 2011, 115, 1992-2004

[11ver-eme_2] Sergey P. Verevkin and Vladimir N. Emel'yanenko; Andrey A. Pimerzin and Elena E. Vishnevskaya: Thermodynamic Analysis of Strain in Heteroatom Derivatives of Indene. J. Phys. Chem. A 2011, 115, 12271-12279

[99ver] S.P. Verevkin, Thermochemical investigation on a-methyl-styrene and parent phenyl substituted alkenesThermochimica Acta 326 (1999) 17-25

[19dor-fil] Olga V. Dorofeeva,* Marina A. Filimonova, and Ilya I. Marochkin, Aliphatic Amines: A Critical Analysis of the Experimental Enthalpies of Formation by Comparison with Theoretical Calculations, J. Chem. Eng. Data 2019, 64, 5630-5647

[20dor-fil] Olga V. Dorofeeva, ${ }^{*}$ Marina A. Filimonova, Cyclic aliphatic amines: A critical analysis of the experimental enthalpies of formation by comparison with theoretical calculationsJCT Volume 145, June 2020, 106092

[05eme-ver] Emel'yanenko, V.N.; Verevkin, S.P.; Enthalpies of Formation and Substituent Effects of ortho-, meta, and para-Amino-Toluenes from Thermochemical Measurements and from Ab Initio Calculations. J. Phys. Chem. A, 2005, 109, 3960-3966.

[15ver-eme] Sergey P. Verevkin, Vladimir N. Emel'yanenko, Thermodynamic properties of cyclohexanamines: experimental and theoretical study., Thermochimica Acta, 2015, 608, 40-48

[P86] Pedley, J.P.; Naylor, R.D.; Kirby, S.P. Thermochemical Data of Organic Compounds, 2nd Ed., Chapman and Hall, London, 1986.

[18chi] Robert D. Chirico , Eugene Paulechka, Ala Bazyleva, Andrei F. Kazakov, Thermodynamic properties of 2-methylindole: Experimental and computational results for gas-phase entropy and enthalpy of formation, J. Chem. Thermodynamics 125 (2018) $257-270$ 